\title{
Egészségügyi szakmai irányelv - \\ A diabetes mellitus kórismézéséről, a cukorbetegek antihyperglykaemiás kezeléséről és gondozásáról felnőttkorban
}

Típusa: Klinikai szakmai irányelv

Azonosító: 002029

Megjelenés dátuma: 2017. február 20.

Érvényesség időtartama: 2017. 01. 01. - 2019. 12. 31.

Kiadja: Emberi Erőforrások Minisztériuma - Egészségügyért Felelős Államtitkárság

Nyomtatott verzió: Egészségügyi Közlöny

Elektronikus elérhetőség: https://kollegium.aeek.hu

\section{Tartalomjegyzék}

I. Irányelvfejlesztésben résztvevők. $\ldots \ldots \ldots \ldots \ldots \ldots \ldots \ldots \ldots \ldots \ldots \ldots \ldots \ldots \ldots \ldots \ldots \ldots \ldots \ldots \ldots$

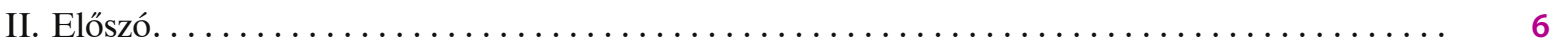

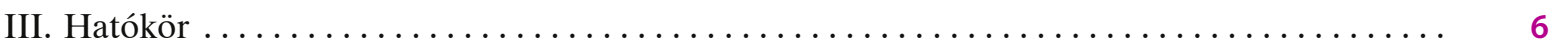

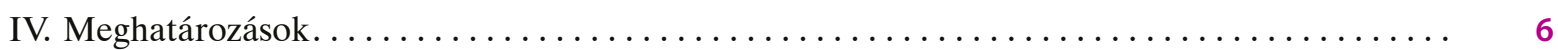

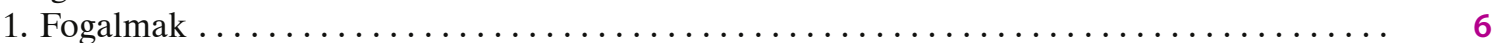

1.1. A diabetes mellitus definíciója ............................. 6

1.2. Az egyénre szabott, individualizált kezelési elv - a kezelési célérték fogalma . . . . . 8

2. Rövidítések ........................................... 8

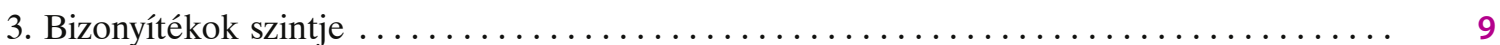

4. Ajánlások rangsorolása..................................... 9

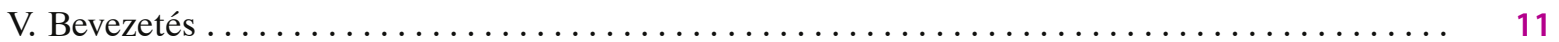

1. A témakör hazai helyzete, a témaválasztás indoklása $\ldots \ldots \ldots \ldots \ldots \ldots \ldots \ldots \ldots \ldots \ldots \ldots$

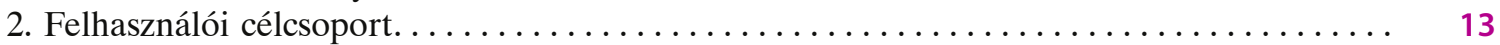

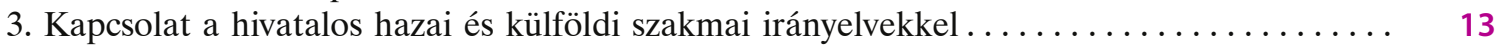




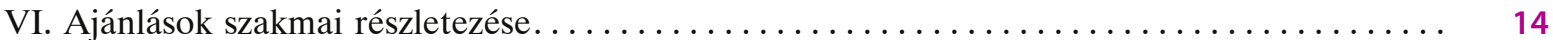

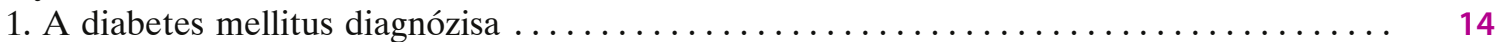

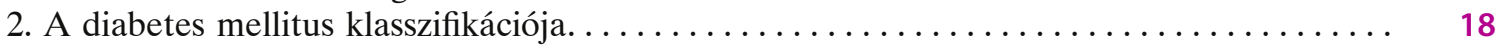

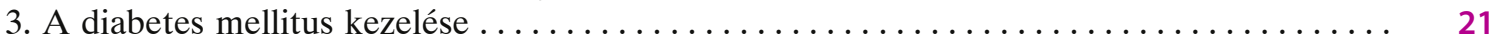

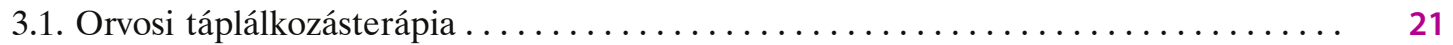

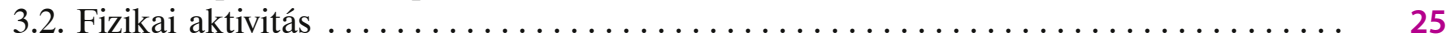

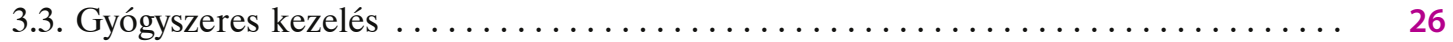

Az 1-es típusú diabetes mellitus antihyperglykaemiás kezelése $\ldots \ldots \ldots \ldots \ldots \ldots .26$

A 2-es típusú diabetes mellitus antihyperglykaemiás kezelése ............ 31

Kezelés nem-inzulintermészetű vércukorcsökkentőkkel 2-es típusú diabetesben . . 31

Kezelés inzulinnal 2-es típusú diabetesben .................... 41

3.4. Pancreas- és Langerhans-sziget-transzplantáció .................... 45

3.5. A súlytöbblet/elhízás kezelése cukorbetegségben $\ldots \ldots \ldots \ldots \ldots \ldots \ldots \ldots \ldots \ldots \ldots \ldots \ldots \ldots$

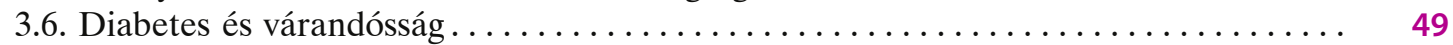

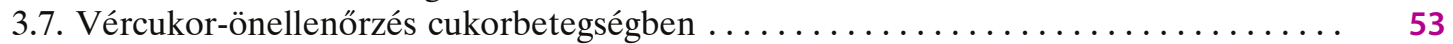

3.8. Folyamatos szövetiglukóz-monitorozási rendszer (CGMS: continuous glucose

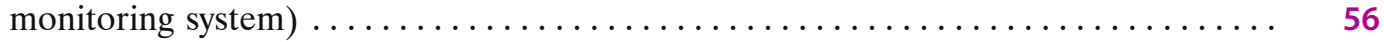

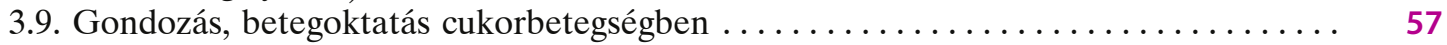

3.10. A diabetes megelőzésének lehetőségei........................... 59

VII. Javaslatok az ajánlások alkalmazásához............................. 60

1. Az alkalmazás feltételei a hazai gyakorlatban $\ldots \ldots \ldots \ldots \ldots \ldots \ldots \ldots \ldots \ldots \ldots \ldots \ldots \ldots$

1.1. Ellátók kompetenciája (pl. licence, akkreditáció stb.), kapacitása ........... 61

1.2. Speciális tárgyi feltételek, szervezési kérdések (gátló és elősegítő tényezők, és azok

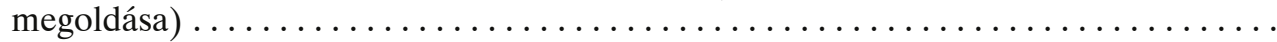

1.3. Az ellátottak egészségügyi tájékozottsága, szociális és kulturális körülményei, egyéni elvárásai

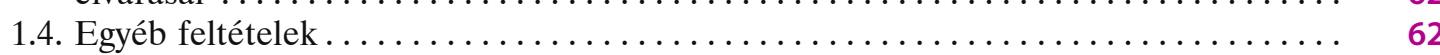

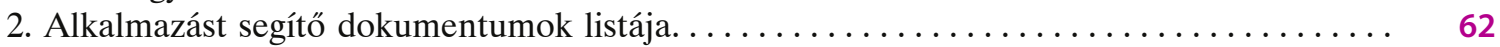

3. A gyakorlati alkalmazás mutatói, auditkritériumok ................... 62

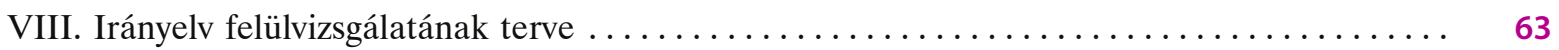

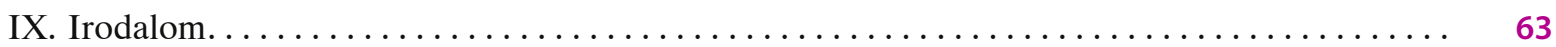

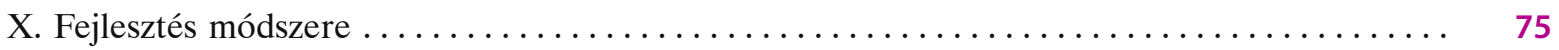

1. Fejlesztőcsoport megalakulása, a fejlesztési folyamat és a feladatok dokumentálásának

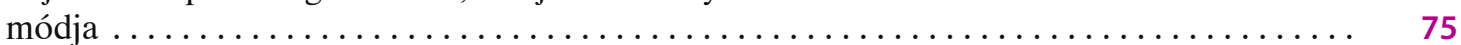

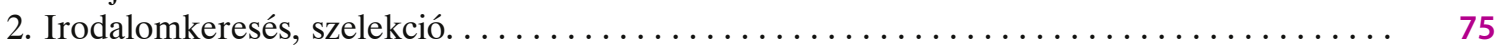

3. Felhasznált bizonyítékok erősségének, hiányosságainak leírása (kritikus értékelés, „bizonyíték vagy ajánlás mátrix”), bizonyítékok szintjének meghatározási módja....... 76

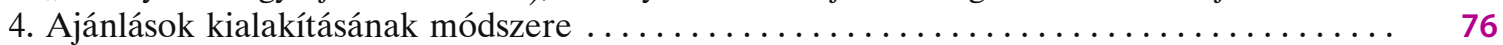

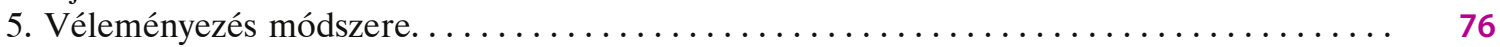

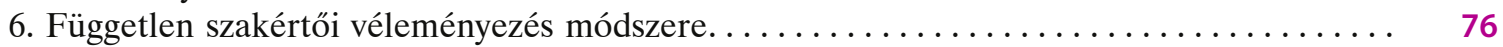

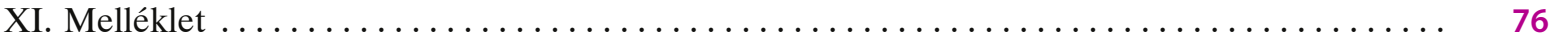

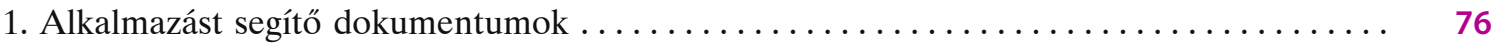




\section{Irányelvfejlesztésben résztvevők}

\author{
Társszerző Egészségügyi Szakmai Kollégiumi \\ Tagozat(ok):
}

1. Belgyógyászat, endokrinológia, diabetes és anyagcsere-betegségek Tagozat

Dr. Jermendy György, tudományos igazgató, az MTA doktora, c. egyetemi tanár, Bajcsy-Zsilinszky Kórház, Budapest, társszerző, szerkesztő

Dr. Gaál Zsolt, osztályvezető főorvos, Szabolcs-Szatmár-Bereg Megyei Kórházak és Egyetemi Oktatókórház, Jósa András Egyetemi Oktatókórház, IV. sz. Belgyógyászati Osztály, Nyíregyháza, társszerző

Dr. Gerő László, az MTA doktora, egyetemi tanár, Semmelweis Egyetem ÁOK, I. Belgyógyászati Klinika, Budapest, társszerző

Dr. Hidvégi Tibor PhD, főorvos, Petz Aladár Megyei Oktató Kórház, Endokrin, anyagcsere és diabetológiai belgyógyászati osztály, Győr, társszerző

Dr. Kempler Péter, az MTA doktora, egyetemi tanár, Semmelweis Egyetem ÁOK I. Belgyógyászati Klinika, Budapest, társszerző

Dr. Winkler Gábor, osztályvezető főorvos, egyetemi tanár, az MTA doktora, Szent János Kórház-Rendelőintézet és Egyesített Intézményei, II. Belgyógyászat-Diabetológia Oktató Osztály, Budapest; Miskolci Egyetem Egészségügyi Kar, Elméleti Egészségtudományi Intézet, Miskolc, társszerző

Dr. Wittmann István, az MTA doktora, egyetemi tanár, Pécsi Tudományegyetem, ÁOK II. sz. Belgyógyászati Klinika és Nephrológiai Centrum, Pécs, társszerző

\section{Véleményező Egészségügyi Szakmai Kollégiumi Tagozat(ok):}

1. Fog és szájbetegségek Tagozat (Prof. Dr. Fejérdy Pál: egyetemi tanár, $\mathrm{PhD}$, tagozatvezető, véleményező; Dr. Bartha Károly, egyetemi docens, $\mathrm{PhD}$, véleményező)

2. Geriátria és Krónikus ellátás Tagozat (Prof. Dr. Bakó Gyula: tagozavezető, tanszékveze- tő egyetemi tanár, az MTA doktora, véleményező)

3. Belgyógyászat, endokrinológia, diabetes és anyagcsere-betegségek Tagozat (Prof. Dr. Karádi István: tagozatvezető, egyetemi tanár, véleményező)

4. Dietetika, humán táplálkozás Tagozat (Henter Izabella: diétetikus, tagozatvezető, véleményező)

5. Ápolás és szülésznői Tagozat (Mészáros Magdolna: ápolási igazgató, tagozatvezető, véleményező)

6. Nefrológia és dialízis Tagozat (Prof. Dr. Wittmann István: tagozatvezető, egyetemi tanár, véleményező)

7. Szülészet és Nőgyógyászat, asszisztált reprodukció Tagozat (Dr. Demeter János: tagozatvezető, egyetemi tanár, véleményező)

8. Orvosi laboratóriumi Tagozat (Dr. Kappelmayer János: tagozatvezető, egyetemi tanár, véleményező)

9. Háziorvosi ellátás Tagozat (Dr. Szabó János: tagozatvezető, háziorvos, véleményező)

„Az egészségügyi szakmai irányelv készítése során a szerzői függetlenség nem sérült."

„Az egészségügyi szakmai irányelvben foglaltakkal a fent felsorolt egészségügyi szakmai kollégiumi tagozatok vezetői dokumentáltan egyetértenek."

\section{Az irányelvfejlesztés egyéb szereplöi}

- Betegszervezet(ek) tanácskozási joggal: nem vett részt

- Egyéb szervezet(ek) tanácskozási joggal: nem vett részt

- Szakmai társaság(ok) tanácskozási joggal:

- Magyar Diabetes Társaság (MDT) (Prof. Dr. Kempler Péter, egyetemi tanár, az MTA doktora, az MDT elnöke, belgyógyász-diabetológus)

- Független szakértő(k): nem vett részt 


\section{Előszó}

$\Lambda$ bizonyítékokon alapuló egészségügyi szakmai irányelvek az egészségügyi szakit segítik meghatározott egészségügyi környezetben. A szisztematikus módszertannal kifejlesztett és alkalmazott egészségügyi szakmai irányelvek, tudományos vizsgálatok által igazoltan, javítják az ellátás minőségét. Az egészségügyi szakmai irányelvben megfogalmazott ajánlások sorozata az elérhető legmagasabb szintű tudományos eredmények, a klinikai tapasztalatok, az ellátottak

\section{Hatókör}

\section{Egészségügyi kérdéskör}

Diabetes mellitus (cukorbetegség; 1-es típusú diabetes, 2-es típusú diabetes, egyéb speciális típusú diabetes, gesztációs diabetes)

\section{Ellátási folyamat szakasza(i)}

Szűrés, diagnosztika, terápia, gondozás, megelőzés

Érintett ellátottak köre

Felnőttkorban (>18 év) diabetes mellitusban szenvedő betegek

\section{Meghatározások}

\section{Fogalmak}

\subsection{A diabetes mellitus definíciója}

A diabetes mellitus (cukorbetegség, cukorbaj) olyan anyagcsere-betegség, amelynek központjá- szempontjai, valamint a magyar egészségügyi ellátórendszer sajátságainak együttes figyelembevételével kerülnek kialakításra. Az irányelv szektorsemleges módon fogalmazza meg az ajánlásokat. Bár az egészségügyi szakmai irányelvek ajánlásai a legjobb gyakorlatot képviselik, amelyek az egészségügyi szakmai irányelv megjelenésekor a legfrissebb bizonyítékokon alapulnak, nem pótolhatják minden esetben az egészségügyi szakember döntését, ezért attól indokolt esetben dokumentáltan el lehet térni.

\section{Érintett ellátók köre}

\section{Szakterület}

0100 belgyógyászat

0105 nephrológia

0113 endokrinológia

0123 diabetológia

0400 szülészet-nőgyógyászat

5000 orvosi laboratóriumi diagnosztika

6301 háziorvosi ellátás

Egyéb specifikáció

Nincs.

ban a szénhidrát-anyagcsere zavara áll, de a kórfolyamat következményesen érinti a zsír- és a fehérje-anyagcserét is. A cukorbetegség alapvető oka az inzulin viszonylagos vagy teljes hiánya, ill. az inzulinhatás elmaradása. Bizonyos körülmények között mindkét eltérés együttesen fordulhat elő. 
A cukorbaj okozta patofiziológiai eltérések számos szerv működését károsíthatják. A cukorbetegségnek ismeretesek heveny és idült (micro- és macroangiopathiás) szövődményei. A diabetes és szövődményeinek kezelése nagy terhet jelent a betegnek és a társadalomnak egyaránt.

A diabetes mellitus elnevezés - amely szószerinti fordításban édes (mellitus), bő vizelést (diabinein $=$ túlcsordulás) jelent - arra a tünetre utal, hogy a vizeletben cukor jelenhet meg. A diabe- tes mellitus diagnózisának jelenlegi kritériumait 1999-ben közölte az Egészségügyi Világszervezet (WHO), majd annak megújítását 2006-ban tették közzé. ${ }^{1,2}$ Magyarországon is ezt az ajánlást követjük. A cukorbetegség csak látszólag egységes kórkép, a számos típus besorolása, rendszerezése, azaz a diabetes mellitus szindróma felosztása ugyanebben az ajánlásban található meg. A cukorbetegség klinikai tünetei nagyban függenek attól, hogy milyen típusú diabetesről van szó.

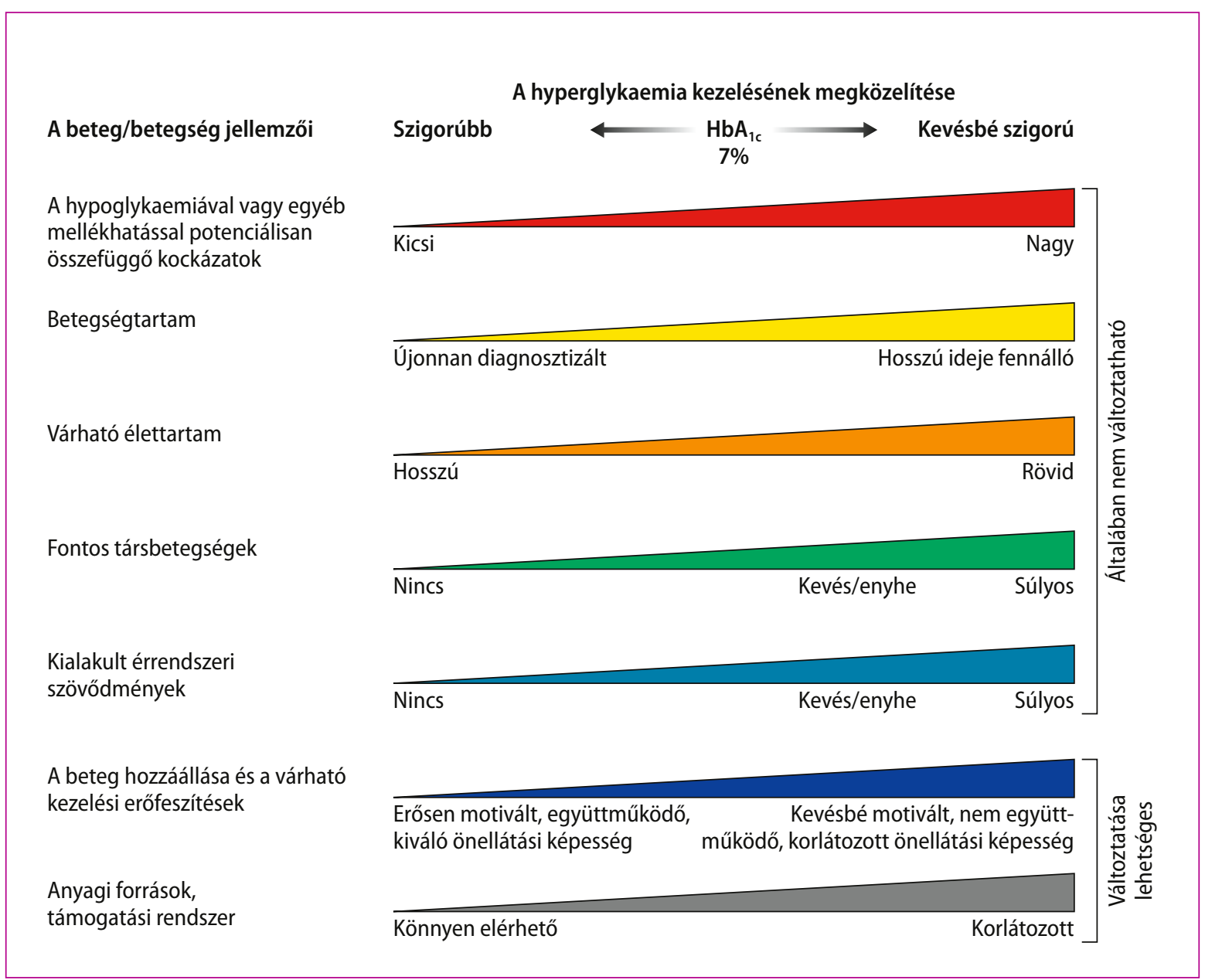

1. ábra. A hyperglykaemia kezelési szigorúságának megítélését segitő döntéshozatali elemek ábrázolása (Forrás: Inzucchi et al.: Diabetes Care 2015; 38[1]: 140-149.)

Egy adott körülménnyel kapcsolatos komolyabb aggályt a lejtő magasságának emelkedése jelzi. Eszerint a balra található körülmények esetén szigorúbb eröfeszitések megengedhetök az alacsonyabb HbA1c elérése érdekében, a jobb oldaliak esetén a kevésbé szigorú célértékek javasolhatók. Ahol lehetséges, az ilyen döntéseket a beteggel együtt kell meghozni, a preferenciáik, igényeik és értékeik szerint. A "skála” célja nem a merev alkalmazásra való buzdítás, hanem a klinikai döntés segítése. 


\subsection{Az egyénre szabott, individualizált kezelési elv - a kezelési célérték fogalma}

$\mathrm{Az}$ egyénre szabott, individualizált kezelés elve először kellő hangsúllyal az ADA/EASD 2012. évi szakmai állásfoglalásában jelent meg, ${ }^{3}$ a 2015. évi megújított változat az elvet minimális módosítással átvette. ${ }^{4}$ A betegközpontú megközelítés azt jelenti, hogy a terápia megválasztáskor maximálisan tekintettel kell lenni az adott beteg egyedi körülményeire, tulajdonságaira. A betegközpontú megközelítésből adódik, hogy a kijelölt kezelési célértéket individuálisan kell meghatározni, fenn lehet tartani a korábban sokat hangoztatott glykaemiás kezelés célértéket $\left(\mathrm{HbA}_{1 c}<7,0 \%\right)$ általános célként, de arra alkalmas betegnél a kezelési cél lehet ennél szigorúbb (alacsonyabb $\mathrm{HbA}_{1 c}$-érték), ill. idősebb, szövődményekben vagy társbetegségekben szenvedő, rövidebb várható élettartammal rendelkezők esetén sokkal engedékenyebb is (olykor a $8,0 \%$ feletti $\mathrm{HbA}_{1 c}$-célérték is elfogadható). Így helyesebb glykaemiás kezelési célérték $\left(\mathrm{HbA}_{1 \mathrm{c}}\right.$ $<7,0 \%)$ helyett kezelési céltartományról $\left(\mathrm{HbA}_{1 \mathrm{c}}\right.$ 6,0-8,0\%) beszélni. A vércukorcsökkentő terápia megválasztásakor - mérlegelve a beteg egyéni tulajdonságait, kérését - lehetünk szigorúbbak vagy kicsit engedékenyebbek (1. ábra), s minden esetben a választandó gyógyszer előnyeit és alkalmazásának kockázatát kell mérlegelnünk, mielőtt a döntést - a beteggel együtt - meghozzuk.

\section{Rövidítések}

AACE: Amerikai Klinikai Endokrinológusok Társasága (American Association of Clinical Endocrinologists); ACE: Amerikai Endokrinológiai Kollégium (American College of Endocrinology); ADA: Amerikai Diabetes Társaság (Amercian Diabetes Association); BMI: testtömeg-index (body mass index); BOT: bázisinzulinnal kiegészített orális kezelés (basal insulin supplemented oral treatment); BPD+DS: duodenum-szájaztatással összekötött biliopancreatikus duodenum diversio (biliopancreatic duodenum diversion et duodenal switch); CDA: Kanadai Diabetes Társaság (Canadian Diabetes Association); CGMS: folyamatos szövetiglukóz-monitorozási rendszer (continuous glucose monitoring system); DCCT: Diabetes Control and Complications Trial; DPA: docosapenténsav (docosa penthenic acid); DPP: dipeptidilpeptidáz; EASD: Európai Diabetes Társaság (European Association for the Study of Diabetes); eGFR: becsült (estimated) GFR (glomerularis filtrációs ráta); EPA: eicosapenténsav (eicosa penthenic acid); EPO: erythropoetin; ESC: Európai Kardiológiai Társaság (European Society of Cardiology); FDA (US): (Amerikai) Gyógyszer- és Élelmiszerellenőrző Hatóság ([US] Food and Drug Administration); GCK: glukokináz; GDM: gesztációs diabetes mellitus; GFR: glomerularis filtrációs ráta; GLP-1: glukagonszerű peptid-1; GLP-1-RA: GLP-1-receptoragonisták; GYEMSZI: Gyógyszerészeti és Egészségügyi Minőség- és Szervezetfejlesztési Intézet; $\mathbf{H b A}_{\mathbf{1 c}}$ : hemoglobin $\mathrm{A}_{1 \mathrm{c}}$; hsCRP: nagy szenzitivitású $\mathrm{C}$-reaktív protein (high sensitivity C-reactive protein); ICT: intenzív konzervatív inzulinterápia; IDF: Nemzetközi Diabetes Szövetség (International Diabetes Federation); IFG: emelkedett éhomi vércukor (impaired fasting glycemia); IGT: csökkent glukóztolerancia (impaired glucose tolerance); IMT: intenzív keverék (inzulin) terápia (intensive mixture therapy); ISO: Nemzetközi Szabványügyi Szervezet (International Organization for Standardization); LADA: lassú kialakulású autoimmun diabetes a felnőttkorban (latent autoimmune diabetes in adults); LAGB: laparoscopos gyomorszűkítés (laparoscopic gastric bandage); MDT: Magyar Diabetes Társaság; MIDD: anyai ágon öröklődő diabetes és süketség (Maternally Inherited Diabetes and Deafness); MNT: orvosi táplálkozásterápia (medical nutrition therapy); MODY: felnőttkori cukorbetegség fiatalkorban (maturity onset diabetes of the young); MUFA: egyszeresen telítetlen zsírsav (monounsaturated fatty acid); NPH-inzulin: Neutralis Protamin Hagedorn inzulin; OAD: orális antidiabetikum; OBDK: Országos Betegjogi, Ellátottjogi, Gyermekjogi és Dokumentációs Központ; OEP: Országos Egészségbiztosítási Pénztár; OGTT: orális glukóztolerancia-teszt; PPAR: peroxisoma proliferációt aktiváló receptor; PPT: prandialis premix terápia (prandial premix therapy); PUFA: többszörösen telítetlen zsírsav (polyunsaturated fatty acid); RYGB: Roux-Y gyomor bypass (Roux-en-Y gastric bypass); SFA: telített zsírsav (saturated fatty acid); SGLT: nátrium-glukóz kotranszporter; UKPDS: United Kingdom 
Prospective Diabetes Study; WHO: Egészségügyi Világszervezet (World Health Organization)

\section{Bizonyítékok szintje}

A szakmai irányelv ezen a téren az ADA (Amerikai Diabetes Társaság) évek óta használt, legutóbb 2016-ban közzétett rendszerén nyugszik. ${ }^{5}$

\section{I. szint}

- Egyértelmű, általánosítható bizonyíték randomizált kontrollált, megfelelően tervezett és vezetett klinikai tanulmányokból, mint pl.

- multicentrikus tanulmányból származó bizonyíték

- metaanalízisből származó bizonyíték, amely magában foglalja a tanulmányok minősítését is

- Támogató jellegü bizonyítékok kellően kivitelezett, randomizált, kontrollált, megfelelő statisztikai erővel rendelkező vizsgálatokból, pl.

- kellően kivitelezett, egy vagy több intézetben végzett vizsgálatból származó bizonyíték

- metaanalízisből származó bizonyíték, amely magában foglalja a tanulmányok minősítését is

\section{II. szint}

- Támogató jellegü bizonyíték kellően kivitelezett kohorsz-tanulmányokból, mint pl.:

- kellően kivitelezett, prospektív jellegü, vizsgálatból vagy regiszterből származó bizonyíték

- kellően kivitelezett, metaanalízisből vagy kohorsz-vizsgálatokból származó bizonyíték

- Támogató jellegủ bizonyíték kellően kivitelezett eset-kontroll tanulmányokból

III. szint

- Támogató bizonyíték gyengén kivitelezett vagy kontroll nélküli tanulmányokból, mint pl.:

- bizonyíték randomizált klinikai tanulmányokból, amelyek esetében egy vagy több nagyobb, ill. három vagy több kisebb módszertani gyengeségből adódóan az eredmények megbízhatósága kétséges

- bizonyíték obszervációs jellegű vizsgálatból, ahol a befolyásolás lehetősége nagy (pl. történelmi kontrollt használó eset-kontrollos vizsgálatok)

- bizonyíték esetközlésből vagy néhány esetet felölelő tanulmányból

- Az ajánlást támogató bizonyíték ellentmondásos.

IV. szint

- Szakértői konszenzus vagy klinikai tapasztalat

\section{Ajánlások rangsorolása}

- „A” Az ajánlás I. szintű bizonyítékon nyugszik. A terápia vagy beavatkozás előnyével kapcsolatban általános a szakmai egyetértés. A terápia vagy beavatkozás hatékony, hatásos, előnyös, ezért az javasolt.

- „B” Az ajánlás II. szintu” bizonyítékon nyugszik. A terápia vagy beavatkozás előnyével kapcsolatban kisebb a szakmai egyetértés. A terápia vagy beavatkozás előnyét, hatékonyságát kevesebb bizonyíték támasztja alá. A terápia vagy beavatkozás adható, alkalmazható.

- „C” Az ajánlás III. szintű bizonyítékon nyugszik. A terápia vagy beavatkozás előnyével kapcsolatban a szakmai egyetértés nem teljesen egyöntetű. A terápia vagy beavatkozás előnyét, hatékonyságát szerény bizonyíték támasztja alá. A terápia vagy beavatkozás szóba jön, mérlegelhető.

- „E” Csak szakértői állásfoglalás (expert opinion), klinikai tapasztalat áll rendelkezésre (IV. szintű bizonyíték). A terápia, beavatkozás szóba jön. Az aktuális gyakorlat a későbbiekben változhat az újabb bizonyítékok fényében.

A bizonyítékok mérlegelése a klinikai döntéshozatalnak csak egy komponensét jelenti. A klinikus mindig egy adott beteget $\mathrm{s}$ nem betegcsoportot kezel. A beteg egyedi sajátosságai (társuló betegségek, életkor, várható élettartam, iskolázottsági szint, mozgáskorlátozottság, s mindenekfelett a beteg kívánsága) olyan körülmények, amelyek az 
ajánlásokban megfogalmazott kezelési céloktól és terápiás stratégiától való eltéréshez vezethetnek.

A szakmai irányelvek döntően a tényeken alapuló orvostudomány (evidence-based medicine) eredményein alapulnak. A tényeken alapuló orvostudomány számos értékes adattal bővítette ismereteinket az elmúlt két-három évtizedben. A diabetológiai tevékenység egyik alapvető tényét, a jó anyagcserekontroll szövődményeket megelőző, ill. azok progresszióját lassító hatását ma már nemcsak véleményként, hanem tényként kezeljük, miután azt 1-es típusú diabetesben a DCCT, 2-es típusú diabetesben pedig a UKPDS eredményei igazolták. Ezeknek a vizsgálatoknak késői utánkövetési eredményeiből ismertük meg a metabolikus memória fogalmát, amelyet ma már szélesebb kontextusban vaszkuláris memóriaként is említhetünk. Az anyagcserehelyzet és a 2-es típusú diabetes makrovaszkuláris szövődményeinek alakulása terén újabb klinikai vizsgálatok (ADVANCE, ACCORD, VADT, ORIGIN, HEART2D) eredményei bővítették ismereteinket, több vizsgálatnak utánkövetése is ismertté vált (ADVANCEON, ACCORDION). A STENO-2 vizsgálat a 2-es típusú diabetes intenzív, multifaktoriális kezelésének előnyét dokumentálta a standard kezeléssel szemben. Számos vizsgálat nyomán tudjuk ma, hogy a diabeteshez társuló hypertonia kezelésében kiemelt jelentősége van az ACE-gátlóknak (HOPE, MICRO-HOPE), ill. 2-es típusú diabetesben a nephropathiához csatlakozó hypertonia kezelésében az ARB-nek (IRMA, RENAAL, IDNT, NESTOR). A 2-es típusú diabetest ma megelőzhető betegségként tartjuk számon, több vizsgálat (STOP-NIDDM, DPP, FDPS, DREAM, ACTNOW, PIPOD, TRIPOD) eredményei alapján. A vércukor-önellenőrzés fontosságát 2-es típusú diabetesben több tanulmány (ROSSO, SHEP) igazolta. A statinok adása 2-es típusú diabetesben ma már szinte kivétel nélkül kötelező, mert ennek előnyét több tanulmány (ACCORD, CARDS) bizonyította.

Számos gyógyszer a napi kezelési gyakorlatban elfoglalt helyét annak köszönheti, hogy előnyét randomizált, kontrollált klinikai tanulmányban igazolni lehetett (pl. pioglitazon: PROACTIVE, alfa-liponsav: ALADIN). Ugyanígy, randomizált kontrollált tanulmányok eredményei szerint, egyes vélt előnyök szerény vagy hiányzó bizonyíté- ka alapján a kezelés nem vált a mindennapi gyakorlat kötelező részévé (fenofibrát a kardiovaszkuláris szövődmények csökkentése érdekében: FIELD, ACCORD), ill. randomizált, kontrollcsoport vizsgálatok metaanalízise nyomán készítmény felfüggesztésére, majd kivonására is került sor (rosiglitazon).

Napjaink jellegzetessége, hogy a forgalomba kerülő új antidiabetikumokkal kapcsolatban randomizált, kontrollált klinikai tanulmányokon alapuló komplex vizsgálatsorozatot terveznek, ill. végeznek, s ez alapozza meg az új gyógyszer regisztrálását (pl. liraglutid: LEAD, exenatid QW: DURATION, lixisenatid: GET GOAL, dulaglutid: AWARD).

A diabetológiai gyógyszerek befogadásával kapcsolatban néhány éve új hatósági előírásként jelent meg, hogy a készítmények kardiovaszkuláris biztonságosságáról megfelelően tervezett, kontrollcsoportos vizsgálatot kell végezni. Az inkretintengelyen ható készítményekkel kapcsolatban 2016-ig három vizsgálat eredménye vált ismertté (saxagliptin: SAVOR, alogliptin: EXAMINE, sitagliptin: TECOS), a GLP-1-mimetikumok közül kettő fejeződött be (lixisenatid: ELIXA, liraglutid: LEADER), s már megismerhettük az első SGLT2-gátló készítménnyel folytatott vizsgálat eredményét is (empagliflozin: EMPA-REG OUTCOME).

$\mathrm{Az}$ antidiabetikumok és a daganatos betegségek kockázata napjaink egyik égető kérdése. A tisztánlátáshoz nyilvánvalóan olyan klinikai vizsgálatok is szükségesek, amelyek megfelelnek a tényeken alapuló orvostudomány elveinek. Több év telt el addig, amíg a glargin és a daganatos betegségek közötti esetleges összefüggés megnyugtatóan tisztázódott (nem igazolódott). Napjainkban ugyanez a kérdés most kezd nyugvópontra jutni az inkretintengelyen ható készítményekkel, ill. a pioglitazonnal kapcsolatban (nem igazolható fokozott kockázat).

A fenti példák a teljesség igénye nélkül szemléltetik, hogy a tényeken alapuló orvostudomány számos vonatkozásban megtermékenyítette, szilárd alapokra helyezte az orvoslást, ${ }^{6}$ közte a diabetológiai betegellátást. Ugyanakkor tudnunk kell arról is, hogy a tényeken alapuló orvostudománynak vannak sajátosságai (árnyoldalai) is, ${ }^{7,8}$ s ezekre is tekintettel kell lennünk akkor, amikor egy gyógyszerről vagy eljárásról véleményt formálunk. 
Összefoglalva, az alábbiakat érdemes szem előtt tartani:

- A tényeken alapuló orvostudomány nélkül az orvosi tevékenység helyessége, indokoltsága bizonytalanabb lenne.

- A randomizált, kontrollált klinikai tanulmányokat és a metaanalíziseket eredetiben célszerű tanulmányozni, nem elégséges szóróanyagokból tájékozódni.

- Az eredményeket kritikus szemmel kell értékelni.

- Nem lehet minden orvosi beavatkozás vagy gyógymód létjogosultságát randomizált, kontrollált klinikai vizsgálattal alátámasztani.

- A betegek ellátása során a betegség patofiziológiai alapjainak ismerete alapvetően szükséges, ennek jelentőségét a tényeken alapuló orvostudomány eredményei sem halványíthatják el.

\section{Bevezetés}

\section{A témakör hazai helyzete, a témaválasztás indoklása}

\section{A témakör hazai helyzete}

A diabetes mellitus a XXI. század elejének egyik legjelentősebb népegészségügyi problémájává vált és előkelő helyet foglal el a nem fertőző ún. „civilizációs" betegségek sorában. Az International Diabetes Federation (IDF) mérvadó becslése szerint a 2015-ben 415 millióra tartott cukorbetegszám (a 20-79 éves egyének körében) 2040-re várhatóan 642 millióra emelkedik (a prevalencia 8,8\%-ról 10,4\%-ra nő). ${ }^{9}$ Érdekesség, hogy az IDF hasonló jellegű közlése 2011-ben világméretekben 366 millióra tartott cukorbetegről tett említést, s a 2030-ra becsült betegszámot 551 millióban adták meg. ${ }^{10}$ Egyelőre napjainkra az jellemző, hogy egy adott évre előrebecsült össz-betegszámot végül mindig meghaladja a betegszám későbbi, tényleges alakulása.

Magyarországon a felnőttkorban előforduló cukorbetegség gyakoriságáról - központi regiszter hiányában - pontos adatokkal nem rendelkezünk. A térségünk külföldi adatait, a világméretű
- A szakmai irányelv sohasem egy adott betegre vonatkozó, mérlegelés nélkül alkalmazandó útmutatás. A beteg egyéni tulajdonságaira mindig tekintettel kell lenni, s a szakmai irányelvtől adott esetben - megfelelő indok alapján és dokumentált módon - el is lehet térni.

- Orvosi döntés előtt az összes körülmény mérlegelése szükséges, a mérlegelés körébe mindig bele kell vonni az adott kérdéssel kapcsolatban rendelkezésre álló bizonyítékokat és az adott beteg/betegség egyedi tulajdonságait/jellegzetességeit is.

- A tényeken alapuló orvostudomány fokozatos térnyerése sohasem iktathatja ki a gondos orvosi mérlegelés szükségességét.

Az egyes ajánlások irodalmi hátterét az adott alfejezetben feltüntetett források képezik. trendet tekintve hazánkban az ismert cukorbetegség gyakoriságát sokáig 6,0-7,0\%-ra becsültük, a cukorbeteg-populáción belül a döntő hányadnál (90\%-ot meghaladó többségnél) 2-es típusú diabetest feltételezve. Egy hazai, 2010-ben publikált reprezentatív szűrővizsgálat eredményei alapján a 20-69 év közötti populációban a diabetes elöfordulása $8,65 \%$ volt, ami a teljes $20-69$ éves populációra vetítve 7,47\%-os súlyozott előfordulási gyakoriságot jelentett. ${ }^{11}$ Az IDF Atlas 2014-ben a cukorbetegek prevalenciáját Magyarországon a 20-79 év közötti populációban 7,51\%-ban adta meg. ${ }^{12} \mathrm{Az}$ OEP adatbázis-elemzésén alapuló ${ }^{13}$ legújabb hazai közlés a nyilvántartott, antidiabetikumot szedő, ismert 2-es típusú cukorbetegségben szenvedők számát 2014-ben 727000-nek találta (teljes lakosságra vonatkoztatott gyakoriság $7,3 \%) \cdot{ }^{14}$ A standardizált prevalencia közel másfél évtized alatt 4,2\%-ról 6,4\%-ra nőtt, ezek a számadatok jól illeszkednek a korábbi becslésekhez, ill. az említett reprezentatív szűrés eredményéhez.

A nem ismert diabetes és kórmegelőző állapotainak (IFG/IGT) előfordulási gyakoriságáról a Magyar Diabetes Társaság által szervezett, kockázatalapuló szűrés eredményei tudósítanak. ${ }^{15} \mathrm{~A}$ 
felnőtt egyének körében, háziorvosok bevonásával 2010-2011-ben végzett szűrés első fázisában a nemzetközileg validált FINDRISC kérdőív magyar változatának kitöltésére került sor, második fázisában pedig a $\geq 12$ pontértékekkel rendelkezők körében orális glukózterhelés (OGTT) történt. A szűrővizsgálatban 70432 felnőtt, háziorvosi rendelőben bármely okból megjelent személy vett részt. Feldolgozásra 68476 kérdőív bizonyult alkalmasnak, a kérdőívek között 28077 (41\%) volt $\geq 12$ pontértékủ. Előírás szerinti OGTT 22846 esetben történt, e csoportban 3217 fö $(14,08 \%)$ esetében IFG, 5663 esetben $(24,77 \%)$ IGT, 1750 esetben $(7,66 \%)$ manifeszt, de a szürés időpontjáig nem ismert diabetes mellitus volt kórismézhető. Összességében véve az OGTT eredményével rendelkezők között 46,53\%-ban diabetes mellitus vagy kórmegelőző állapota (IGT, IFG) volt megállapítható.

$\mathrm{Az}$ ismert 2-es típusú cukorbetegség prevalencia-növekedése eléggé általános jelenség, ${ }^{16,17}$ ez általánosságban a várható élettartam emelkedésével, a lakosság elöregedésével áll összefüggésben. Hazánkban a várható élettartam az utóbbi években értékelhetően növekedett, ${ }^{18}$ az utóbbi közel két évtized hazai epidemiológiai történései a krónikus nem-fertőző betegségek progressziójának késleltetésével és az elhalálozás időpontjának posztponálásával jellemezhető. ${ }^{19}$ A már említett hazai OEP-adatbázis-elemzésben a 2-es típusú cukorbetegségben szenvedők 60 év felettiek aránya 2011-ben a teljes lakosság hasonló életkori tartományának 20\%-át tette ki, ami azt jelenti, hogy ebben az életkorban minden ötödik felnőtt egyén ismert módon 2-es típusú diabetesben szenved. ${ }^{14}$

Napjaink jellegzetes gondja, hogy a 2-es típusú diabetes manifesztációja egyre fiatalabb életkor felé tolódik el.20 Ezzel összefüggésben új, korábban nem észlelt diabetes-típus, a gyermek- és ifjúkori 2-es típusú cukorbetegség észlelése már hazánkban sem számít ritkaságnak. ${ }^{21}$

A 2-es típusú diabetest megelőző glukózintolerancia-stádiumok (IGT, IFG) gyakoriságáról hazánkban kevés adattal rendelkezünk. A hazai reprezentatív szűrés ${ }^{11}$ eredményei alapján a 20-69 éves populációban az IFG gyakorisága 4,88\%-nak (súlyozott gyakoriság 4,39\%) adódott (a vizsgálat éhomi vércukorérték meghatározásán alapult, így az IGT előfordulásáról adat nem volt nyerhe- tő). Szűrővizsgálatok általános tapasztalata szerint minden ismert cukorbetegre egy fel nem ismert diabetesben szenvedő egyén esik. Az IDF Atlas 2015-ben úgy foglalt állást, hogy felnőttkorban a diabetes-esetek kb. 50\%-a nem ismert, nem diagnosztizált. ${ }^{9}$ Ha ezeket az adatokat tekintjük, akkor hazánkban kb. másfél-kétmillió ember szenved ismert vagy ismeretlen módon diabetesben, ill. kórmegelőző állapotaiban.

$\mathrm{Az}$ 1-es típusú diabetes incidenciája napjainkban világméretekben növekszik, bár a 2-es típusú diabeteshez viszonyítva a növekedés üteme szerényebb, mert az 1-es típusú diabetes incidencia-emelkedése átlagosan csak évi 3\%-ra tehető. A Magyar Gyermekdiabetes Regiszter közel 30 évre visszanyúló adatokkal rendelkezik, adatai a 0-14 éves populációban előforduló, 18 megyére kiterjedő 1-es típusú diabetesre vonatkoznak. E regiszter adatai szerint az 1-es típusú diabetes incidencia-növekedése hazánkban 1978-2002 között átlagosan évi 5,1\% volt. Az 1989-2009 közötti periódusban 3432 új esetet regisztráltak, az incidencia az 1989-ben talált 7,7/100 000/év-ről 20 év alatt 18,2/100000/év-re növekedett. A regiszter 2010-től az egész országra kiterjed. Eszerint a legutóbbi, 2011-es incidencia 20 eset/100000 gyermeklakos/év volt. Ez 1,6 ezrelékes prevalenciának felel meg, azaz Magyarországon minden hatszázadik, 15 évnél fiatalabb gyermek diabetesben szenved. $^{22,23},{ }^{24}$

Napjaink újabb felismerése, hogy 2-es típusú diabetes klinikai képében megjelenhet a lassú kialakulású felnőttkori autoimmun diabetes (LADA) is, amelyet a diagnosztikus lehetőségek bővülésével egyre gyakrabban kórisméznek. ${ }^{25}$ A LADA prevalenciája a 2-es típusnak kórismézetteken belül a UKPDS adatai alapján kb. 10\%-ra tehető, egyes felmérések alapján a hazai gyakoriság a 2-es típusúnak tartott cukorbetegek körében hasonló nagyságrendű lehet. ${ }^{26}$

\section{A témaválasztás indoka}

Az epidemiológiai adatok alapján nyilvánvaló, hogy hazánkban a cukorbetegség népbetegség-jellegűnek tekinthető. A betegek nagy száma, az idült szövődmények előfordulása jelentős terhet jelent az érintett egyéneknek és a teljes egészségügyi ellátó hálózatnak. A szakmai irányelv ki- 
adásának indokát képezi ugyanakkor az is, hogy a terápiás lehetőségek az évek folyamán jelentősen bővültek, a gyógyszerkutatás és -fejlesztés különösen napjainkban intenzív és eredményes. Számos új készítménnyel bővült a terápiás paletta az elmúlt néhány évben, amelyeknek helyét a kezelési rendszerben nemzetközi szinten is szakmai állásfoglalások jelölik ki. Indokolt hazánkban is a terápiás lehetőségeket áttekinteni, s kijelölni a tényeken alapuló orvostudomány elve szerint az adott készítményeknek a terápiás rendszerben elfoglalt helyét.

A cukorbetegség kezelése terén az inzulin felfedezése a XX. század egyik legjelentősebb orvostudományi áttörése volt: a korábban halálos kimenetelű, mai nevezéktan szerint 1-es típusú cukorbetegségben szenvedő egyének élete megmenthetővé vált. Az elmúlt kilenc és fél évtizedben az inzulinkutatás hatalmas ívet futott be, a harmincas években megjelent az NPH-inzulin, az 50-es években pedig a Lente-inzulin. A 80 -as éveket a nagyfokban tisztított, monokomponens (MC) sertésinzulinok elterjedése jellemezte, míg a 90-es évek elején a humán inzulin (HM) teljes térhódítása következett be. A következő fejlesztési lépcső nyomán az inzulinanalógok különböző képviselői (gyors hatású, hosszú hatású, ill. bifázisos készítmények) váltak elérhetővé. Az utóbbi 1-2 évben az ellátásban már rendelkezésre áll az első biohasonló inzulin (bioszimiler glargin) is.

A cukorbetegek orális antidiabetikus kezelési lehetőségei az elmúlt években új hatástani csoportokkal bővültek, s a jelenlegi kutatási eredmények alapján valószínűsíthető, hogy ez a terápiás paletta az elkövetkezendő években még tovább fog bővülni. Az elmúlt években elérhetőkké váltak az inkretintengelyen ható készítmények közé tartozó DPP-4-gátlók. A legújabb hatástani csoportot az SGLT-2-gátlók jelentik, két képviselője már hazánkban is bekerült a napi klinikai gyakorlatba.

$\mathrm{Az}$ inkretintengelyen ható GLP-1-receptoragonisták (használatos az inkretinmimetikumok kifejezés is) injektábilis, nem-inzulinszerű készítmények. Legutóbb az egyik képviselő (liraglutid) inzulinnal (degludekkel) fix kombinációs kiszerelése bővítette a hazai terápiás palettát.

$\mathrm{Az}$ irányelvben azokat a gyógyszereket említjük, amelyek a kézirat összeállításának időpontjában (2016. augusztus) hazánkban (és az Európai
Unióban) regisztrálva vannak és azok a hazai betegek számára ténylegesen el is érhetők.

A cukorbetegek kezelési lehetőségei nemcsak a szorosan vett, s egyre korszerűbb antidiabetikus gyógyszerek elérhetőségével, hanem a technikai újdonságok révén a gyógyászati segédeszközök és a mủtéti eljárások terén is rohamosan fejlődött. Indokolt, hogy a cukorbeteg-ellátással szoros öszszefüggésben álló ezen lehetőségeket a szakmai irányelv is áttekintse.

A szakmai irányelv a társszerzők és a szerkesztő álláspontja szerint általános jellegü irányelvek összefoglalására hivatott. Egyes társszakmák feladatainak és kompetenciáinak részletes felsorolása nem lehet a szakmai irányelv szerves része, azok kidolgozása és publikálása a társszakmák feladatát képezik.

\section{Felhasználói célcsoport}

Felnőttkorú (>18 év) cukorbetegekkel foglalkozó egészségügyi szolgáltatók, akik diabetes mellitus szűrésével, diagnosztizálásával, kezelésével, gondozásával és megelőzésével foglalkoznak.

\section{Kapcsolat a hivatalos hazai és külföldi szakmai irányelvekkel}

\section{Kapcsolat a korábbi hazai szakmai} irányelvekkel

Az MDT szakmai irányelv legutolsó két megújításának $(2011,2014)$ sorsa hányatott módon alakult, nem az MDT hibájából (hivatalos változata végül nem látott napvilágot, de az irányelv teljes terjedelemben megjelent a Diabetologia Hungarica hasábjain és az MDT honlapján). ${ }^{27,28}$ Az Egészségügyi Közlönyben elérhető (hivatalos) utolsó szakmai irányelv 2009-ben készült. ${ }^{29}$

A jelenlegi szakmai irányelv szorosan követi a GYEMSZI, majd később az OBDK előírásait. A megírás körülményei arra kényszerítették az írásban szerepet vállaló szakmai grémiumot, hogy a korábbi szakmai irányelvnél szűkebb változatot készítsen. Ebből adódóan a jelenlegi szakmai irányelv - noha tartalmilag értelemszerüen támaszkodik az előző változatokra - teljesen új 
irányelvnek tekintendő. Markáns változás a korábbi verziókhoz képest, hogy a címbe belekerült az „antihyperglykaemiás” jelző. Ebből adódóan jelenleg a terápiás javaslatok csak az antidiabetikus kezeléssel kapcsolatosak, s nem szerepelnek benne azok a részek, amelyeknél a társszakmák bevonása nélkülözhetetlen lett volna (retinopathia, neuropathia, nephropathia, macroangiopathia diabetica, hypertonia diabetesben, lipideltérések diabetesben, mütét és diabetes). Így volt remélhető, hogy az elkészítésre megadott határidőt tartani lehessen.

A fentiek alapján a 2013-ban írt, 2014-ben publikált korábbi szakmai irányelv megújítása helyett egy új szakmai irányelvet írt a szakmai grémium. A korábbi (2014) és a jelenlegi szakmai irányelv fejezeteinek írói azonosak. Az illetékes szakmai kollégium tagozatának és tanácsának megbízatása 2016 elején lejárt, az új kollégium felállása időben elhúzódik, ezért a megíráshoz változatlan szerzői gárdával kezdtünk hozzá, az MDT vezetőségének döntése alapján.

\section{Kapcsolat külföldi szakmai irányelv(ek)kel}

A jelenlegi szakmai irányelv értelemszerủen támaszkodik a nemzetközi ajánlásokra is, amelyek közül elsősorban az alábbiakkal kapcsolódik egyes vonatkozásokban.

ADA-EASD szakmai állásfoglalása (2012, 2015).34 A két szakmai társaság állásfoglalásának előzményei egészen 2006-ig nyúlnak vissza, a je- lenlegi szakmai irányelv a 2012. és 2015. évi megújítások számos ajánlását (egyénre szabott kezelés, a 2-es típusú diabetes kezelésének algoritmusa) átvette, hazai viszonyokra adaptálta.

AACE és ACE kezelési algoritmusa (2016).30 $\mathrm{Az}$ újonnan felismert 2-es típusú diabetes kezelésének szemléletét több vonatkozásban átvettük és hazai viszonyokra adaptáltuk.

A Kanadai Diabetes Társaság klinikai gyakorlati útmutatója $(2013,2015,2016){ }^{31,32,33}$ Az újonnan felismert 2-es típusú diabetes kezelésének szemléletét, a renalis szövődmények esetében alkalmazható gyógyszerek áttekintését átvettük és hazai viszonyokra adaptáltuk.

ADA gyakorlati útmutató a diabetes-gondozáshoz - 2016. Évente megújul, a Diabetes Care januári supplementumában jelenik meg, szabadon letölthető és használható. A jelenlegi irányelvünkben a 2016. évi megújított változatra támaszkodtunk.

EASD-ESC közös irányelve a prediabetes, diabetes és kardiovaszkuláris betegségek gyakorlati ellátásáról. ${ }^{34}$ A 2013-ban megjelent közlemény néhány gondolatát átvettük.

Közép-kelet-európai diabetes-társaságok szakmai állásfoglalása a vércukor-önellenőrzésről 2014..$^{35}$ A vércukor-önellenőrzéssel kapcsolatban több javaslatot átvettünk.

AACE-ACE közös állásfoglalása a glukózmonitorozásról (2016). ${ }^{36}$ A vércukor-önellenőrzéssel, a glukózmonitorozással kapcsolatban több javaslatot átvettünk.

\section{Ajánlások szakmai részletezése}

\section{A diabetes mellitus diagnózisa}

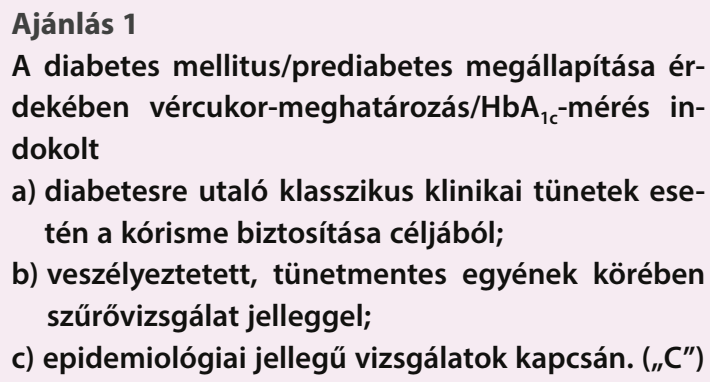

Vércukor-meghatározás indokolt diabetesre utaló tünetek (polyuria, polydipsia, más okkal nem megmagyarázható fogyás, pruritus vulvae, balanitis) fennállása, ill. súlyos tudatzavar vagy coma esetén. Ez esetekben egyetlen vércukor-meghatározás eredménye diagnosztikus lehet, ugyanis ilyen esetekben a vércukor magas, s a vizeletben is cukor mutatható ki. A cukorbetegség klasszikus klinikai tünete a polyuria (a vizelet mennyiségének megnövekedése), a polydipsia (fokozott folyadékfelvétel az állandó szomjúságérzés miatt) és az 
egyéb okkal nem magyarázható fogyás. A fogyás kialakulhat átlagos, fokozott (polyphagia) vagy rossz étvágy mellett. Fentieken kívül a beteg panaszkodhat fáradtságra, az étvágytalanság mellett hányingerre, hányásra; ez utóbbiak már a ketosis tünetei lehetnek. Időnként homályos látás lép fel, amelyet a szemlencsének a hyperosmolaris csarnokvíz miatt megváltozott fénytörése okoz. Nőkön gyakran pruritus vulvae, férfiakon ritkán balanitis alakulhat ki. Visszatérő, nehezen gyógyuló infekciók is felhívhatják a figyelmet a cukorbajra. Olykor lábikragörcs vagy a kézujjakon zsibbadás jelentkezik. Súlyos esetben a kialakuló hyperglykaemiás ketoacidosis vagy a nem-ketotikus hyperosmolaris állapot tudatzavarhoz, eszméletvesztéshez vezethet, és kezelés nélkül halált okozhat. Elsősorban a 2-es típusú diabetes azonban gyakran lehet tünetszegény, ilyenkor a diagnózis egy már elszenvedett szövődmény - myocardialis infarctus, stroke - kapcsán derülhet ki. Természetesen a diabetes kórisméjének megállapítását követően azonnal terápiás teendők válnak szükségessé.

Vércukor-meghatározás szürővizsgálat jelleggel indokolt a veszélyeztetett egyének (45 éves életkor felettiek, pozitív családi anamnézissel rendelkezők, testsúlyfelesleggel [BMI $>25 \mathrm{~kg} / \mathrm{m}^{2}$ ] rendelkezők, hyperlipidaemiások, hypertoniások, nagy magzatot szülő nők, anamnézisben gesztációs diabetes, kórelőzményben kardiovaszkuláris megbetegedés) körében. Tünetmentes egyének esetén a diabetes kórisméjét sohasem szabad egyetlen kóros vércukorérték alapján kimondani. Követelmény, hogy ilyen esetben legalább egy további, más alkalommal történő vizsgálat eredménye is kóros legyen. Ha diabetes vagy prediabetes megállapítható, indokolt, hogy a beteg kezelésbe vonása azonnal megtörténjen, s egyben a további klasszikus kardiológiai rizikófaktorok (vérnyomás, lipidértékek) meghatározását is kezdeményezni kell. Ha a szűrővizsgálat eredménye negatív, ismételt szürés kb. 3 év eltelte után ismételten indokolttá válik. ${ }^{5}$

Epidemiológiai vizsgálatok céljára az éhomi vércukor-meghatározás önmagában elfogadható. Sokkal megbízhatóbb és költséghatékonyabb módszer azonban az ún. kockázatalapú szűrés, amelynek keretén belül kérdőíves (pl. FINDRISC) előszűrést követően a veszélyeztetett egyének körében az előírás szerinti OGTT elvégzése ajánlott. $15,37,38,39$
Klinikai körülmények között, egyedi esetekben, tünetmentes egyénekben diabetes vagy prediabetes gyanúja esetén mindig OGTT végzendő. $\mathrm{Az}$ utóbbi években ezen a téren is előtérbe került a $\mathrm{HbA}_{1 \mathrm{c}}$-meghatározás jelentősége. ${ }^{40,41,42,43} \mathrm{~A}$ $\mathrm{HbA}_{1 \mathrm{c}}$-mérés epidemiológiai vizsgálatokban is elfogadott módszer lett.

\section{Ajánlás 2}

A szénhidrátanyagcsere-zavar stádiumai az éhomi vércukorszint és az OGTT 2 órás értéke alapján állapíthatók meg, de a kategorizálásban hasznosítható a $\mathrm{HbA}_{1 \mathrm{c}}$-érték is. $\left.{ }_{(\text {, }} \mathrm{C}^{\prime \prime}\right)$

Az OGTT végzésekor a helyes kivitelezés kritériumait be kell tartani, a mintavételi időpontok pontos betartására különös figyelmet kell fordítani (1. táblázat). A $\mathrm{HbA}_{1 \mathrm{c}}$-érték alapján történő kategorizálás csak standardizált módszerrel történt mérés eredménye alapján lehetséges. Bizonyos állapotok (pl. haemoglobinopathiák, haemolysis, uraemia, EPO-kezelés) zavarhatják a $\mathrm{HbA}_{1 \mathrm{c}}$-mérést.

$\mathrm{Az}$ OGTT eredménye alapján megállapíthatók a glukózanyagcsere stádiumai (normális glukóztolerancia, emelkedett éhomi vércukor - IFG, csökkent glukóztolerancia - IGT, diabetes). Hazánkban a kategorizálás a WHO 2006. évi kritériumrendszere ${ }^{2}$ alapján történik (2. táblázat).

\section{1. táblázat. Az OGTT (orális glukóztolerancia-teszt) helyes kivitelezésének kritériumai}

\footnotetext{
- A vizsgálatot reggel, éhomra kell végezni, előzetes (minimum 10 órán keresztül tartó) koplalást követően.

- A terhelést megelőző 3 napon keresztül a szokásos, de legalább 150 gramm szénhidrátot tartalmazó étrend tartása szükséges.

- A vizsgálatot megelőző napokban a terhelendő személynek átlagos fizikai tevékenységet kell végeznie.

- A vizsgálatot nyugalmi körülmények között, dohányzás és fizikai aktivitás mellőzésével kell lebonyolítani.

- A vizsgálat eredményét és értékelését esetleg befolyásoló tényezők (infekciók, gyógyszerhatások stb.) fennállását figyelembe kell venni - egyes esetekben indokolt lehet a terheléses vizsgálat halasztása is.

- A teszt elvégzéséhez szükséges 75 gramm glukózt 250-300 ml vízben feloldva, 5 perc alatt kell elfogyasztani.

- A szénhidrát-anyagcsere kategorizálásához elégséges a terheléses vizsgálat 0 . és 120 . percében mért értéket figyelembe venni. Egyéb klinikai és experimentális célok további időpontokban történő vizsgálatot is indokolttá tehetnek.
} 
A $\mathrm{HbA}_{1 c}$-érték alapján történő stádium-besorolás határértékeit a 3. táblázat tartalmazza. ${ }^{5}$

Élettani körülmények között - nem terhes állapotban - az éhomi vércukorszint $\leq 6,0 \mathrm{mmol} / \mathrm{l}$ és az OGTT 2 órás értéke <7,8 mmol/l. A WHO 2006. évi ajánlása nem ad meg pontos számadatot a normoglykaemia definiálására, csupán azt tünteti fel, hogy normoglykaemiának tekintendő az az állapot, amely esetében a diabetes mellitus és a kardiovaszkuláris megbetegedések kialakulásának kockázata

2. táblázat. A normális glukóztolerancia és a szénhidrátanyagcsere-zavarok diagnosztikai kritériumai $(\text { WHO, 2006) })^{2}$

\begin{tabular}{|c|c|}
\hline $\begin{array}{c}\text { A szénhidrát-anyagcsere } \\
\text { állapota }\end{array}$ & $\begin{array}{l}\text { Glukózkoncentráció, } \\
\text { mmol/l (vénás plazma, } \\
\text { laboratóriumi mérés) }\end{array}$ \\
\hline $\begin{array}{l}\text { Normális glukóztolerancia: } \\
\text { • Éhomi vércukorszint } \\
\text { - OGTT } 2 \text { órás érték }\end{array}$ & $\begin{array}{l}\leq 6,0 \\
<7,8\end{array}$ \\
\hline $\begin{array}{l}\text { Emelkedett éhomi vércukor (IFG) } \\
\text { - Éhomi vércukorszint és } \\
\text { - OGTT } 2 \text { órás érték }\end{array}$ & $\begin{array}{c}\geq 6,1 \text { de }<7,0 \text { (azaz: 6,1-6,9) } \\
<7,8\end{array}$ \\
\hline $\begin{array}{l}\text { Csökkent glukóztolerancia (IGT)* } \\
\text { - Éhomi vércukorszint és } \\
\text { - OGTT } 2 \text { órás érték }\end{array}$ & $\begin{array}{c}\leq 7,0 \\
\geq 7,8 \text { de }<11,1(\text { azaz: } 7,8-11,0)\end{array}$ \\
\hline $\begin{array}{l}\text { Diabetes mellitus } \\
\text { • Éhomi vércukorszint vagy } \\
\text { • OGTT } 2 \text { órás érték }\end{array}$ & $\begin{array}{l}\geq 7,0 \\
\geq 11,1\end{array}$ \\
\hline
\end{tabular}

* Ha a 2 órás értéket nem mérik, akkor a kórisme bizonytalan marad. Abban az esetben, ha a 2 órás érték megfelel az IGT-nek és az éhomi vércukorérték $<6,0 \mathrm{mmol} / \mathrm{l}$, akkor izolált IGT áll fenn. Az IGT egyéb esetei IFG és IGT együttes fennállását valósítják meg, a hivatalos nevezéktan azonban csak az IGT kategória nevet használja.

3. táblázat. $A H b A_{1 c}$-érték kategóriái az ADA ajánlá$s a^{5}$ alapján

\begin{tabular}{|c|c|}
\hline $\mathrm{HbA}_{1 c}$-érték & Anyagcsere-állapot \\
\hline$\leq 5,6 \%$ & normális \\
\hline $5,7-6,4 \%^{*}$ & prediabetes \\
\hline$\geq 6,5 \% *$ & diabetes mellitus \\
\hline
\end{tabular}

* Az ADA 2010-ben tett először közzé ajánlást, amely javasolta a $\mathrm{HbA}_{1 c}$-érték bevonását a diagnosztikai kritériumrendszerbe (diabetesre jellemző érték $\geq 6,5 \%$, fokozott diabetes-kockázatra utaló érték 5,7-6,4\%). A javaslatot a WHO 2011-ben, az IDF 2012-ben elfogadta azzal, hogy a standard módon mért, a 6,5\%-ot elérő vagy meghaladó $\mathrm{HbA}_{1 c}$-érték diagnosztikus a diabetes jelenlétére, az 5,7-6,4\% közötti tartomány jelentőségéről egyelőre kevés adattal rendelkezünk. Az ADA 2016. évi állásfoglalása már határozottabban fogalmaz: DCCT szerint kalibrált méréssel $\mathrm{HbA}_{1 \mathrm{c}} \geq 6,5 \%$ diabetesre, 5,7-6,4\% érték prediabetesre utal. kicsi (a vércukor-számértékek pedig a prediabetesre jellemző számértékek alatt maradnak).

A diabetes mellitus diagnosztikus kritériumát el nem érő, de a fiziológiás értékektől eltérő vércukorszintek a szénhidrát-anyagcsere enyhébb zavarára utalnak. Az emelkedett éhomi vércukorszint (impaired fasting glycaemia, IFG) és a csökkent glukóztolerancia (impaired glucose tolerance, IGT) a cukoranyagcsere átmeneti állapotai a normális glukóztolerancia és a diabetes mellitus között. Az IFG és az IGT egymással nem helyettesíthető fogalom. Az IFG az éhomi, az IGT pedig a postprandialis állapotnak az élettanitól való eltérését jelenti. Az IFG-t és IGT-t együttesen régebben károsodott glukózreguláció (impaired glucose regulation), ill. köztes hyperglykaemia (intermediate hyperglycemia) névvel illették, az utóbbi időben azonban a prediabetes elnevezés vált általánosan elfogadottá. ${ }^{44,45,46}$

IFG (emelkedett éhomi vércukor) állapítható meg, ha az éhomi plazma glukóz értéke $6,1 \mathrm{mmol} / 1$ vagy nagyobb, de kisebb, mint 7,0 $\mathrm{mmol} / \mathrm{l}$. Egyedi esetekben minden emelkedett éhomi vércukor (IFG) esetén indokolt az OGTT elvégzése. Ennek elvégzésekor a 2 órás érték alapján az adott egyén lehet IGT-s vagy diabeteses is, de ez utóbbi két kategóriát csak az OGTT eredménye alapján lehet kimondani. Ha a 2 órás vércukorérték normális, IFG állapítható meg, $s$ az egyén követése ajánlott.

Meg kell jegyezni, hogy 2003 második felében az ADA az éhomi vércukor normális-kóros határát $5,5 \mathrm{mmol} / \mathrm{l}-\mathrm{re}$ (vénás plazma érték) javasolta leszállítani, következésképpen az IFG kritériuma ezek szerint az 5,6-6,9 mmol/l közötti tartomány lenne. Az új határérték helyességét a szakirodalom erősen vitatja, s az egyelőre Európában nem terjedt el, s azt a WHO sem fogadta el.

IGT (csökkent glukóztolerancia) csak OGTTvel ismerhető fel. IGT akkor állapítható meg, ha az éhomi vércukorszint $<7,0 \mathrm{mmol} / \mathrm{l}$ és az OGTT 2 órás értéke $\geq 7,8 \mathrm{mmol} / 1$, de $<11,1 \mathrm{mmol} / \mathrm{l}$ (egyszerűbben kifejezve 7,8-11,0 mmol/1 közötti, beleértve természetesen a két szélső értéket). Abban az esetben, ha a 2 órás érték megfelel az IGT-nek és az éhomi vércukorérték 6,1-6,9 mmol/l közé esik, akkor IGT + IFG együttes fennállása állapítható meg. Ha az éhomi vércukor $\leq 6,0 \mathrm{mmol} / \mathrm{l}$ és a terhelés utáni 120 perces vércukorérték 7,8-11,0 mmol/l közötti, akkor izolált IGT állapítható meg. 
Diabetes mellitus állapítható meg

- Ha klasszikus tünetek figyelhetők meg, és

- az éhomi (az utolsó energiafelvételt követően minimum 10 óra múlva mért) vércukorszint kóros, azaz értéke vénás plazmában, enzimatikus módszerrel meghatározva eléri vagy meghaladja a $7,0 \mathrm{mmol} / \mathrm{l}$ értéket, vagy

- étkezés után bármely időpontban mért (random) vércukorszint eléri, vagy meghaladja a $11,1 \mathrm{mmol} / \mathrm{l}$ értéket.

- Ha klasszikus tünetek hiányában

- az éhomi vércukorszint értéke két különböző alkalommal mérve eléri, vagy meghaladja a $7,0 \mathrm{mmol} / \mathrm{l}$ értéket; vagy

- az OGTT kapcsán az éhomi vércukor eléri vagy meghaladja a 7,0 mmol/1 értéket és/vagy a 120 perces érték eléri vagy meghaladja a 11,1 mmol/l értéket (a kóros terhelési eredmény egy másik időpontban végzett méréssel megerősítendő); vagy

- a standard módon mért $\mathrm{HbA}_{1 c}$-érték $\geq 6,5 \%$.

Klasszikus tünetek hiányában a három módszer (éhomi vércukor, OGTT kapcsán 0. és 120. perces vércukor, $\mathrm{HbA}_{1 c}$ ) választási lehetőséget jelent, mindegyiknek vannak előnyei és korlátai. A klinikai gyakorlatban OGTT végzése vagy $\mathrm{HbA}_{1 c}$-mérés ajánlott.

A vércukorérték alapján történő diagnózis megállapításához professzionális szintű laboratóriumi meghatározás szükséges. A fent közölt számszerű vércukor-határértékek laboratóriumban, enzimes módszerrel, vénás plazmából történő meghatározásra érvényesek. Bár a kisméretű, hordozható, a cukorbetegek ellenőrzésére vagy önellenőrzésre használt vércukormérők mérési megbízhatósága napjainkban sokkal jobb, mint évekkel ezelőtt, a jelenleg érvényes szakmai állásfoglalás szerint glukométer mérési eredménye alapján a cukorbetegség kórisméjét megállapítani nem lehet.

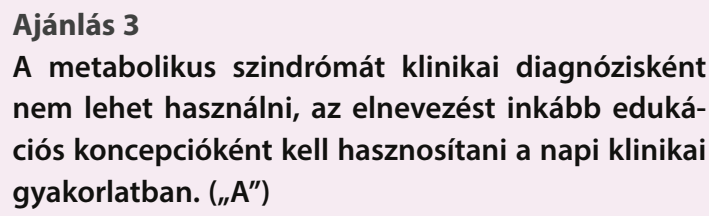

A metabolikus szindróma a fogalom megteremtése (1988) után a klinikai kutatás érdeklődésének az előterébe került. ${ }^{47,48}$ Közel két évtized után is- mertté vált az is, hogy a metabolikus szindróma, ill. a talaján kifejlődő 2-es típusú diabetes mellitus és a daganatos kórképek, egyes mentális betegségek, az alvási apnoe szindróma és a nem-alkoholos steatohepatitis gyakran együtt fordulnak elő. Egyre több adat szól a mellett is, hogy a központi idegrendszernek jelentős szerepe van az anyagcsere és az energiaforgalom szabályozásában, s a napszaki bioritmus genetikai vagy környezeti okokból eredő megváltozása - többek között - a kardiovaszkuláris és metabolikus kockázat növekedését vonja maga után. ${ }^{49}$ Ugyanakkor 2005-2006 táján erős kritikákat is megfogalmaztak a metabolikus szindrómával kapcsolatban..$^{50,51} \mathrm{Az}$ ADA és az EASD a 2005-ben kiadott közösen közleményükben $^{52}$ a szindrómával kapcsolatos kételyeket nyolc pontban foglalták össze:

1. A szindróma egyik kritériumrendszere sem kellően megalapozott.

2. A diabetes bevonása a kritériumrendszerbe indokolatlan, kérdéses.

3. Nem kellően bizonyított, hogy az inzulinrezisztencia a háttérben álló alapvető, egyedüli oki tényező.

4. Több kardiovaszkuláris kockázati tényező bevonása vagy mellőzése esetleges.

5. A szindróma kardiovaszkuláris kockázatot előrejelző értéke attól függően változik, hogy az adott személynél mely kockázati tényezők vannak jelen.

6. A szindróma által jelzett kardiovaszkuláris kockázat nem nagyobb, mint az egyes összetevőké összegezve.

7. Az egyes összetevők kezelésén túl a szindrómának egyéb, specifikus terápiája nincs.

8. A szindróma diagnosztizálásának klinikai hasznossága kérdéses.

A WHO 2010-ben, ${ }^{53,54}$ az MDT Metabolikus Munkacsoportja 2011-ben ${ }^{55}$ áttekintette a metabolikus szindróma klinikai jelentőségét. Ennek nyomán megállapítható, hogy

- A metabolikus szindróma nevezéktanilag nem tartozik a prediabetes közé.

- A metabolikus szindrómát klinikai diagnózisként nem lehet használni.

- A metabolikus szindrómát betegség-megelőző állapotnak kell értelmezni, így az nem foglalhatja magába a diabetest vagy az ismert kardiovaszkuláris betegséget. 
- A metabolikus szindrómát inkább edukációs koncepcióként kell hasznosítani, a metabolikus szindróma klinikai gyakorlati haszna erősen korlátozott.

\section{4. táblázat. A szénhidrátanyagcsere-zavarok etiológi- ai klasszifikációja (WHO, 2006)}

- 1-es típusú diabetes mellitus (béta-sejt-károsodás

következtében általában abszolút inzulinhiány áll elő)

- autoimmun mechanizmusú

- idiopathiás

- 2-es típusú diabetes (a diabetes széles tartományát átfogja, a dominálóan inzulinrezisztencián alapuló, relatív inzulinhiánnyal társuló formáktól az elsődlegesen szekréciós zavarra visszavezethető, inzulinrezisztenciával társuló vagy anélkül megjelenő formákig)

- Egyéb speciális típusok

- a béta-sejt-működés genetikai zavarai

- az inzulinhatás genetikai zavarai

- a pancreas exocrin részének megbetegedéseihez társuló formák

- endocrinopathiák

- gyógyszerek és kémiai anyagok kiváltotta típusok

- infekciókhoz társuló

- az immungenezisű diabetes szokatlan formái

- más, esetenként diabetesszel társuló genetikai szindrómák

- Gesztációs diabetes mellitus

\section{A diabetes mellitus klasszifikációja}

\section{Ajánlás 4}

A diabetes kórisméjének megállapítását követően törekedni kell a diabetes-típus meghatározására, a diabetes klasszifikációjára. ("C")

A diabetes mellitus etiológiai jellegű klasszifikációja alapján négy alapvető típus (1-es típusú diabetes mellitus, 2-es típusú diabetes mellitus, egyéb speciális típusok, gesztációs diabetes mellitus) különíthető el (2. ábra) ${ }^{56}$ A diabetes két alapvető típusa az 1-es típusú és a 2-es típusú diabetes mellitus (korábban IDDM: inzulindependens diabetes mellitus, ill. NIDDM: nem-inzulindependens diabetes mellitus). Külön csoportot képeznek az egyéb, specifikus típusok és a gesztációs diabetes mellitus. Az egyes diabetes-típusok megállapításánál nincs jelentősége annak, hogy aktuálisan milyen terápiával kezelik a beteget (pl. a 2-es típusú diabetes típusa nem változik akkor, ha az orális antidiabetikus kezelés helyére inzulinterápia lép).

A diabetes klasszifikációja átlagos esetben nem okoz nehézséget (4. táblázat). Mindig vannak azonban olyan esetek, ahol a klasszifikáció nehéz, de ebben az esetben sem szabad késlekedni a kezelés megkezdésével.

\begin{tabular}{|c|c|c|c|c|c|}
\hline \multirow[t]{3}{*}{ Stádiumok } & \multirow{3}{*}{$\begin{array}{c}\text { Normoglykaemia } \\
\text { Normális glukózreguláció }\end{array}$} & \multicolumn{4}{|c|}{ Hyperglykaemia } \\
\hline & & \multirow{2}{*}{$\begin{array}{c}\text { Csökkent glukóztolerancia } \\
\text { vagy } \\
\text { Emelkedett éhomi vércukor } \\
\text { (prediabetes) }\end{array}$} & \multicolumn{3}{|c|}{ Diabetes mellitus } \\
\hline & & & $\begin{array}{c}\text { Inzulint } \\
\text { nem igénylő }\end{array}$ & $\begin{array}{l}\text { Inzulin szükséges } \\
\text { az anyagcsere- } \\
\text { kontrollhoz }\end{array}$ & $\begin{array}{c}\text { Inzulin } \\
\text { szükséges } \\
\text { a túléléshez }\end{array}$ \\
\hline \multicolumn{6}{|l|}{ 1-es típus* } \\
\hline \multicolumn{6}{|l|}{ 2-es típus } \\
\hline \multicolumn{6}{|l|}{ Egyéb speciális típusok ${ }^{* *}$} \\
\hline \multicolumn{6}{|l|}{ Gesztációs diabetes** } \\
\hline \multicolumn{6}{|c|}{$\begin{array}{l}\text { * Elöfordul, hogy ketoacidosis tünetei után rövid időn belül normoglykaemia detektálható, s antidiabetikus gyógyszeres kezelés nem szükséges } \\
\text { (,honeymoon” periódus) }\end{array}$} \\
\hline \multicolumn{6}{|c|}{$\begin{array}{l}\text { ** Ritkán előfordul, hogy idetartozó betegek esetében a túléléshez inzulin adása válik szükségessé } \\
\text { (pl. Vacor-mérgezés, 1-es típusú diabetes kialakulása terhesség alatt) }\end{array}$} \\
\hline
\end{tabular}

\section{2. ábra. A glukózanyagcsere rendellenességei: típusok és stádiumok (Forrás: Diabetes Care 2011; 34[Suppl.1])}




\section{1-es típusú diabetes mellitus}

A béta-sejtek károsodása olyan diabetes mellitus létrejöttét eredményezi, ahol az érintett egyén életben maradásához inzulin alkalmazása szükséges. Inzulin nélkül ketoacidoticus coma, végül halál következik be. A kórkép általában klasszikus klinikai tünetekkel, zömében 35 év előtt manifesztálódik (korábbi nomenklatúra: IDDM), de az életkor alapján önmagában nem lehet a diabetes típusát megállapítani. Az 1-es típusú diabetest a korai stádiumban autoimmun folyamat fennálltát jelző autoantitestek (szigetsejt-, anti-GAD-, tirozinfoszfatáz- vagy inzulin-ellenes antitestek) kimutathatósága jellemzi (a meghatározásra csak kiemelt laboratóriumokban van lehetőség). Az 1-es típusú diabetesre gyermekek és serdülők esetén a klinikai kép gyors progressziója jellemző, bár a betegségre vezető autoimmun folyamat lényegesen korábban elkezdődik. Felnőttkorban ismeretesek lassan kialakuló formák is, amelyeket latens autoimmun formaként (latent autoimmune diabetes in adults, LADA) írtak le. A pancreas béta-sejt-funkciójának károsodására a C-peptid-mérés eredményeiből lehet következtetést levonni. A genetikai sajátosságok, az autoantitest-profil és az inzulin(C-peptid-) szekréció vizsgálata alapján a LADA nem önálló kórkép, hanem az 1-es típusú diabetes mellitus lassú progressziójú formája és ezért kórismézésekor inzulinkezelés indokolt. Klinikailag a 2-es típustól az elkülönítése nehéz lehet, a diagnózisában az autoantitest (GADA, ICA) kimutatása a döntő. ${ }^{25} \mathrm{Az}$ 1-es típusú diabetesben szenvedők egy részénél más autoimmun betegségek (Basedow-Graves-betegség, Hashimoto-thyreoditis, Addison-kór, gluténszenzitív enteropathia) társulása is kimutatható.

Az 1-es típusú diabetesnek vannak olyan formái is, ahol a kóreredet nem ismert és nem mutatható ki autoimmun folyamat jelenléte sem. Ezeket az eseteket „idiopathiás 1-es típusú diabetes” formaként jelölik. Ez a forma gyakrabban észlelhető ázsiai, ill. afrikai származású egyénekben.

\section{2-es típusú diabetes}

A diabetes leggyakoribb formája, amelyet az inzulinelválasztás és az inzulinhatás károsodása jellemez, ezek közül valamelyik kórtani folyamat az adott esetben meghatározó lehet. Típusos esetben klasszikus tünetek nélkül, elhízáshoz társulóan, 35 év felett jelenik meg (korábbi nomenklatúra: NIDDM).

\section{Egyéb speciális diabetes-formák}

E csoportban a béta-sejt-müködés genetikai zavarai (MODY, MIDD), az inzulinhatás genetikai zavarai, a pancreas exocrin állományának megbetegedéseihez társuló formák, endocrinopathiákhoz csatlakozó, gyógyszerek és kémiai anyagok kiváltotta, infekciókhoz társuló formák, ill. az immungenézisű diabetes szokatlan formái és más, esetenként diabetesszel társuló genetikai szindrómák találhatók.

Jelentőségüknél fogva külön említést érdemelnek az ún. monogénes diabetes-formák. A monogénes diabetesek, amelyekből ma mintegy 20 ismert, egyetlen gén mutációja következtében alakulnak ki. A diabetes szindrómának mintegy 5\%át reprezentálják, de nagymértékben aluldiagnosztizáltak ezek a diabetes-formák. Gyakori, hogy a diabetes manifesztációjakor ezt a diabetes-formát nem ismerik fel. Több vonatkozása inkább a gyermekgyógyászat körébe tartozik, de rövid említésük indokolt a jelenlegi szakmai irányelvben is, miután előfordulhat, hogy a pontos kórismét csak megkésve, fiatal felnőttkorban állapítják meg.

\section{Gesztációs diabetes}

A gesztációs diabetes olyan, különböző súlyosságú hyperglykaemiát okozó szénhidrátanyagcsere-zavar, amely első ízben a terhesség során kezdődik vagy kerül felismerésre. Fogalma nem zárja ki annak a lehetőségét, hogy a glukóz-intolerancia már a terhesség előtt is fennállt, csak korábban nem került kórismézésre. A meghatározás nem tesz különbséget aszerint, hogy az állapot igényel-e inzulinkezelést, vagy sem, ill. hogy fennáll-e a terhességet követően is, vagy sem.

A terhesek általános diabetes-szűrését a terhesség 24-28. hetében indokolt elvégezni. A szűrést a 75 gramm glukózzal történő, standard OGTT formájában kell lebonyolítani. Szülés után leghamarabb 6 héttel, általános esetben ennél később, újabb OGTT végzendő, a reklasszifikáció céljából. A reklasszifikációt elősegítő OGTT eredménye le- 
het normális, de a terhelés utáni 2 órás érték alapján IGT vagy diabetes is megállapítható.

A gesztációs diabetesben szenvedő terhes egy később manifesztálódó diabetes szempontjából fokozott kockázatú egyénnek tekintendő akkor is, ha a reklasszifikáció során normális glukóztolerancia állapítható meg.

(Részleteket 1. a 3.6. fejezetben!)

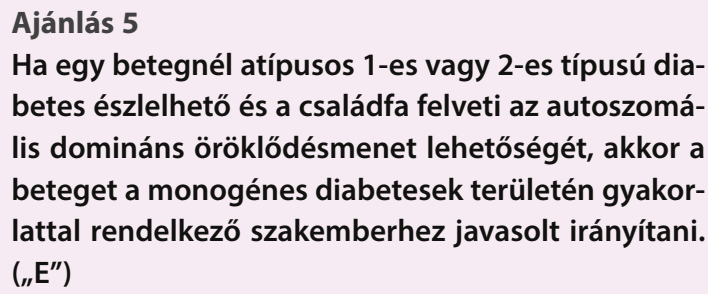

Akkor kerül elötérbe a monogénes diabetes-forma lehetősége, ha atípusos 1-es vagy 2-es típusú diabetes mellett autoszomális domináns vagy anyai ágon öröklődő diabetesesetek fordulnak elő egy családban, vagy ha a diabetes az élet első 6-9 hónapjában alakul ki. A családi halmozódás hiánya azonban nem zárja ki a monogénes diabetes lehetőségét, mivel gyakoriak a de novo mutációk. $5,57,58$

A monogénes diabetes-formák közé tartozó különböző MODY-k (Maturity-Onset Diabetes of the Young) genetikai hátterében legalább 13 gén mutációja áll. Ezen diabetes-formákban általában nincs szükség inzulinkezelésre, jellemző a fiatalkori, a 25. életév előtti kezdet, a kifejezett családi halmozódás. A GCK-MODY (korábban MODY2) hátterében a glukokináz-gén heterozigóta inaktiváló mutációi állnak, míg az ún. transzkripciós-faktor MODY-k, (HNF1A, HNF4A, HNF1B, IPF, NeuroD1) a béta-sejt-fejlődést és -működést befolyásoló gének mutációi következtében alakulnak ki. A MODY esetek mintegy 10\%-ában nem ismert, hogy mely gén mutációja következtében alakul ki a MODY (MODY X). Kiemelendő, hogy a monogénes diabetes-formák mellett kialakulhat egyéb diabetes-forma is egy adott betegnél.

Amennyiben egy családon belül halmozottan fordul elő stabil, éhomi hyperglykaemia, akkor monogénes GCK-MODY valószínűsíthető. A GCK-MODY esetében kezelésre általában nincs szükség, a szövődmények nem jellemzőek, a betegek csaknem mindig tünetmentesek, ez a forma nőknél gyakran gesztációs diabetesként jelent- kezhet. Ezzel szemben a leggyakoribb MODY, a HNF1A-MODY esetében szövődmények alakulnak ki, a vércukorszintek gyorsan emelkednek. Jellemző ezen MODY-típus szulfanilurea-érzékenysége, az érzékenység kb. négyszerese a szokásosnak. Ezen betegek többsége egy idő után inzulinra szorul. Hazánkban 2009-től van lehetőség a leggyakoribb monogénes diabetesek genetikai diagnosztizálásra (részletek: www.diabet.hu/munkacsoportok).

Az anyai ágon öröklődő MIDD (Maternally Inherited Diabetes and Deafness) a mitokondriális DNS-ben bekövetkező mutáció miatt alakul ki. Szenzoneuronális süketség vagy nagyothallás és a klinikai tünetek nagy változatossága jellemzi ezt a diabetes-formát. ${ }^{59}$

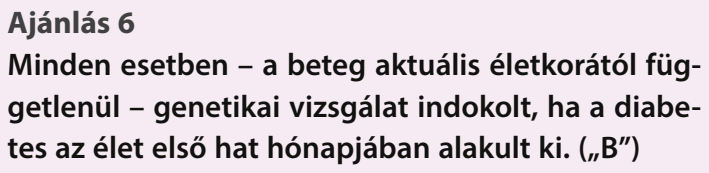

Neonatalis diabetesről beszélünk akkor, ha a diabetes az élet első hat hónapjában manifesztálódik. Ez a diabetes lehet permanens vagy tranziens jellegű. $\mathrm{Az}$ esetek mintegy felében spontán javulás észlelhető (tranziens neonatalis diabetes), míg az esetek másik felében a diabetes perzisztál (permanens neonatalis diabetes mellitus). Korábban ezeket a betegeket 1-es típusúnak tartották, ma tudjuk, hogy leggyakrabban monogénes diabetesről van szó. A permanens neonatalis diabetes mellitus genetikai hátterében az esetek felében a béta-sejt ATP-szenzitív káliumcsatornájának KIR6.2 alegységét kódoló KCNJ11 gén, illetve a SUR1 alegységet kódoló ABCC8 gén mutációi állnak. Ezek a cukorbetegek legtöbbször jól kezelhetők nagy dózisú szulfanilurea-terápiával. ${ }^{60}$ Akár évtizedekkel a diabetes kialakulását követően is sikerrel átállítható a betegek többsége inzulinról szulfanilureára. Leírták már a KCNJ11 gén mutációja által okozott diabetes terhesség alatti sikeres szulfanilurea-kezelését is. ${ }^{61,62}$

Monogénes diabetes-formákat már Magyarországon is leírtak, diagnosztizáltak. A genetikai diagnózis megállapítása lehetővé teszi az egyénre szabott, hatékony terápia megtervezését (pl. inzulin helyett szulfanilurea), a prognózis meghatározását, a család részére pedig a genetikai tanácsadást. ${ }^{63,64}$ A genetikai vizsgálatok drágák, de már 
ma is költséghatékonynak tekinthetők. A genetikai vizsgálat előtt is fontos, hogy kiválasszuk, melyik monogénes diabetes valószínűsíthető. Ebben segítséget nyújthat néhány biomarker is. A hsCRP szintje HNF1A-MODY-ban határérték alatti, ilyen értékek valószínűsítik ezt a monogénes diabetest. Az ún. MODY-kalkulátor néhány egyszerű paraméter megadásával kiszámolja a MODY pozitív prediktív értékét, megkönnyíti a MODY diagnosztizálását fiatal korban (www.diabetesgenes.org). ${ }^{65}$

\section{A diabetes mellitus kezelése}

A cukorbetegség kezelési lehetőségei nem-gyógyszeres (életmódbeli) és gyógyszeres formákra oszthatók, válogatott esetekben kezelési lehetőségként műtéti jellegü beavatkozás (pancreas- vagy Langerhans-szigetsejt-transzplantáció, bariátriai sebészet) is szóba jön.

A nem-gyógyszeres kezelés magában foglalja a megfelelő étrend tartását és a napi rendszerességű fizikai aktivitás végzését. Az étrendi és a fizikai aktivitásra („exercise”) vonatkozó előírások együttese az ún. „életmódkezelés”. A korábban elterjedt "diéta" szóhasználat helyett ma a fogalmat pontosabban kifejező orvosi táplálkozásterápia (medical nutrition therapy [MNT]) elnevezést használjuk, ami a makro- és mikrotápanyagok, élelmi rostok, élvezeti szerek és cukorhelyettesítők alkalmazásával kapcsolatos megfontolások és irányelvek összességét jelenti.

\subsection{Orvosi táplálkozásterápia}

A cukorbetegek étrendje alig különbözik az egészséges étkezéstől: kerülendők a finomított cukrok, a cukrozott üdítőitalok, az édes sütemények, a telített zsírsavakat nagyobb arányban tartalmazó élelmiszerek, előnyben részesítendők a szénhidrátokat természetes formában tartalmazó élelmiszerek, a rostban gazdag zöldségek, gyümölcsök. Kívánatos továbbá, hogy igazodjon az érintett személy kezeléséhez, kezelési céljaihoz, egyéni igényeihez és a társadalmi-kulturális szokásokhoz. Az étrendi előírások célja:

- elősegíteni és támogatni egészséges étkezési minták elsajátítását, a hasznos tápanyagban gazdag élelmiszerek, ételek és ajánlott mennyi- ségeik megismerését az egészség lehető legteljesebb megőrzése céljából, különös tekintettel - a tápláltsági állapottal kapcsolatos egyéni célok elérésére és fenntartására

- az egyéni glykaemiás, vérnyomás- és vérzsírcélértékek biztosítására

- fentiek elérésével és hosszú távú fenntartásával a szövődmények megelőzésére vagy késleltetésére

- az egyéni táplálkozási szükségletek meghatározása, a fenti célok megvalósítását segítő betegegyüttmüködés biztosítása

- választási lehetőségek felkínálásával, étrendi minták kidolgozásával annak erősítése, hogy az érintett személynek a kialakult állapot ellenére sem kell lemondania az étkezés öröméről

- a megszokott, makro- és mikronutriensekre fókuszáló információnyújtással szemben az egyéni igényekhez igazodó étrend gyakorlati ismeretekkel történő segítése.

$\mathrm{Az}$ adekvát táplálkozásterápia a diabetes-prevenció, a kezelés és az önmenedzselés eszköztárának integráns része. Gyakorlott dietetikus irányításával történő elsajátítása 1-es típusú diabetesben 0,3-1,0\%-os, 2-es típusú diabetesben $0,5-2,0 \%$-os $\mathrm{HbA}_{1 \mathrm{c}}$-csökkenést eredményezhet. ${ }^{66}$

$\mathrm{Az}$ étrendtervezés szempontjai a diabetes különböző formáiban részben azonosak (az étrend összetétele), részben eltérőek (energiatartalom, az étkezések gyakorisága). Ez utóbbiakat befolyásolja az érintett személy tápláltsági állapota, energiaszükséglete, fizikai aktivitása, az alkalmazott vércukorcsökkentő gyógyszeres kezelés formája (nem-inzulintermészetű szerek, inzulin), valamint az egyes készítmények farmakokinetikája-farmakodinamikája is (hatáskezdet és -tartam, humán vagy analóg inzulinkészítmények).

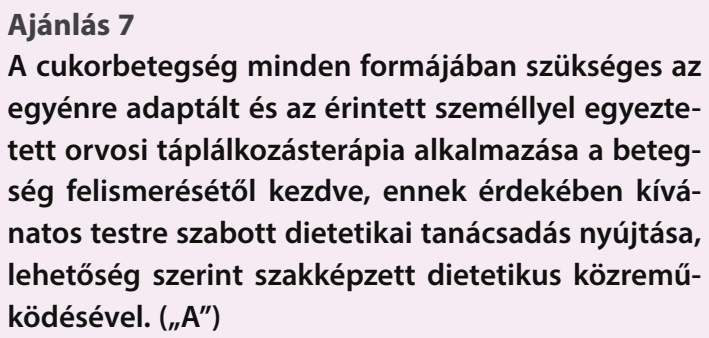

1-es típusú diabetesben a kívülről bejuttatott inzulin biztosítja mind a nyugalmi, mind az étkezési 
inzulinszükségletet. 2-es típusú diabetesben késik a prandialis szekréció korai fázisa, késik és elhúzódó a második, késői fázisa, továbbá, a keringésbe jutó inzulin az inzulinrezisztenciából adódóan nem képes hatását teljes értékűen kifejteni. Az inzulinválasz késéséből adódóan elégtelen vagy elmarad a hepatikus glukózkibocsátás gátlása is, ami tovább emeli az étkezést követő vércukorszintet. Hosszú időn keresztül fennálló 2-es típusú diabetesben is kialakulhat az endogén inzulintermelés teljes megszűnése. A naponta több részre elosztott, szénhidráttartalmában meghatározott étrend segít az étkezések vércukoremelő hatásának korlátozásában. Ennek elsajátítása érdekében kívánatos, hogy minden cukorbeteg esetében meghatározásra kerüljenek a kezelési célértékek, és megismerjék az elérésüket és fenntartásukat biztosító, egyénre adaptált étrendi elveket. ${ }^{4,67}$

\section{Ajánlás 8 \\ A 2-es típusú diabetes minden szakaszában alapve- tően fontos a táplálék energiatartalmának tervezé- se, a szénhidrátfelvétel követése, számolása. („A")}

Normális testtömegű cukorbeteg számára naponta annyi energia felvétele szükséges, amennyit az - életkor, testmagasság, az anyagcsere jellemzői, a végzett napi tevékenység jellege, tartama, intenzitása függvényében - megkíván. Felnőtt, átlagos testalkatú és fizikai aktivitású cukorbetegek napi energiaszükséglete általában $7600-10500 \mathrm{~kJ}$, azaz 1800-2500 kcal (ami 25-30 kcal/kg energiabevitelt jelent). A napi energiaigény betegségeket követő lábadozás, terhesség, szoptatás idején nő, idősek esetében csökken. ${ }^{28}$

A 2-es típusú diabetesben szenvedők többsége túlsúlyos. Az étrendi összetevők arányának és az egészséges táplálkozás szempontjainak biztosítása mellett szükséges az energiabevitel korlátozása. A folyamatos, nem erőltetett mértékủ súlycsökkenés a glykaemiás kontroll javulása mellett hozzájárulhat a vérnyomás- és a vérzsír-értékek rendeződéséhez is. ${ }^{67,68} \mathrm{Az}$ energiaszükséglet napi 500-750 kcal-val történő csökkentése révén (férfiak esetében napi 1500-1800, nők esetében napi 1200-1500 kcal előirányzása, legalább 30 percnyi fizikai aktivitással és magatartásterápiával kiegészítve) fél év alatt $\geq 5 \%$ testsúlycsökkenés biztosítható. ${ }^{68}$
Hangsúlyozni szükséges, hogy az energiatartalom megszorítása a kívánt súlyleadás és/vagy a glykaemia eléréséhez önmagában rendszerint nem eredményes, kellő eredmény csak a napi rendszerességű fizikai tevékenység növelésével együtt várható. ${ }^{67}$

\section{Ajánlás 9}

A cukorbetegek táplálkozása során célszerủ a napi szénhidrát- és energiafelvétel több alkalomra történő elosztása. („E")

Évtizedek során kikristályosodott klinikai tapasztalat, hogy a napi szénhidrát-mennyiséget inzulin nélkül kezelteken - az esetlegesen alkalmazott antidiabetikus kezelés függvényében - három-ötszöri, inzulinnal kezelteken a készítmény típusától függően három-hatszori alkalomra javasolt elosztani. Az alkalmanként kisebb szénhidrátterhelés mérsékli az étkezést követő vércukor-emelkedést, az étkezések gyakoriságának növelése pedig megelőzheti a nem kívánt vércukoresést. Napi háromnál többszöri étkezés esetén az egyes étkezések szénhidráttartalmát fő (hazai viszonyaink között reggeli, ebéd, vacsora) és köztes étkezésekre (szokásosan tízórai és uzsonna) javasolt elosztani. ${ }^{28}$ Indokolt esetben - pl. ha vércukoresés bekövetkezése a gyógyszeres terápia módosításával nem előzhető meg -, az étkezések száma a mért értékekhez vagy az érintett személy kívánságához igazítva növelhető. Ugyanígy, egyenletes vércukorértékek esetén az érintett személy kívánságára az étkezések száma csökkenthető is.

Az étkezést követő vércukorszint-emelkedés maximuma általában egy óra múlva alakul ki, s három órán belül rendszerint lecseng. Az inzulinszekréciót nem befolyásoló tablettás vércukorcsökkentők (metformin, pioglitazon, SGLT-2-gátlók, akarbóz) önmagukban alkalmazva általában nem okoznak vércukoresést, s ennek kockázata alacsony a vércukorfüggő inzulinelválasztást okozó készítmények (DPP-4-gátlók, GLP-1-mimetikumok) esetében is. A hagyományos szekréciófokozó szerek (elsősorban a szulfanilureák, de a glinidek is) azonban „mindent vagy semmit” típusú, vércukorszinttől független inzulinelválasztást eredményeznek, ami vércukoresés fokozott kockázatával jár. Ezt mérsékli az étkezések több részletre történő elosztása. 
A különböző inzulinok hatásgörbéje ettől eltérő, s a vércukorszint alakulását az étkezési (prandialis) és bázisinzulinként alkalmazott készítmények esetleges interferenciája is befolyásol(hat) ja. Humán inzulinnal (gyors hatású reguláris és közepes hatású NPH-inzulinnal) történő kezelés mellett általában 6-7-szeri étkezés javasolt a táplálékfelszívódás és az inzulinok hatásdinamikájának eltéréséből adódó vércukoresések kiküszöbölésére.

Még az ún. intenzív inzulinkezelés keretei között sem védhető ki a vércukor túlzott megemelkedése nagyobb mennyiségü - 80-90 grammot meghaladó - szénhidrát egyszerre történő bevitelét követően, mert a szubkután beadott reguláris, gyors hatású inzulin nem képes olyan gyors ütemben felszívódni és olyan magas vérszintet létrehozni, mint az az egészséges szervezet esetében megfigyelhető. Bár gyors hatású inzulinanalóggal folytatott intenzív konzervatív inzulinkezelés során az alkalmanként nagyobb mennyiségű szénhidrát vércukoremelkedést okozó hatása is jobban ellensúlyozható, a nagy egyszeri szénhidrátbevitel inkább kerülendő.

A fentiekből adódóan gyors hatású inzulinanalóggal (lizpro-, aszpart-inzulinnal vagy glulizinnel) történő kezelés során - étkezési vércukorszint-szabályozó típusú (prandialis glukózregulátor, korábban „glinideknek” nevezett) orális készítményekkel (nateglinid, repaglinid) kezeltekhez hasonlóan - elégséges lehet az étkezés három alkalomra történő meghatározása. Háromszori étkezés általában elegendő napi 2-3 alkalommal bifázisos analóg készítményeket kapók esetében is (ún. prandialis premix [PPT], más elnevezéssel intenzív keverék terápia [IMT]), ritkábban azonban kis köztes étkezés beiktatása, elsősorban délelőtt, ilyenkor is szükséges lehet. ${ }^{28,67}$

\section{Ajánlás 10 \\ A cukorbetegek étrendi összetevőinek arányát és szénhidráttartalmát minden esetben egyénre sza- bottan kell meghatározni. („B”)}

Korábban az 50-55\% szénhidrát - benne $>30$ gramm élelmi rost -, 20-25\% zsír, 15-20\% fehérje összetételü étrend volt az általánosan ajánlott. Ezzel szemben, felmérések szerint nem-terhes, középkorú felnőttek körében a napi energiaszükség- let $\approx 45 \%$-ának szénhidrátokból, $\approx 36-40 \%$-ának zsírból és $\approx 16-18 \%$-ának fehérjéből történő fedezése a leggyakoribb. Különböző étrendek (mediterrán, DASH [Dietary Approaches for Stop Hypertension], vegán, low carb low fat) között nem találtak érdemi különbséget a glykaemiás hatékonyság tekintetében. ${ }^{66,67,69}$ Bár az étrend döntő hányadát a szénhidrátok alkotják, s mind menynyiségük, mind összetételük jelentősen befolyásolja a postprandialis vércukor-emelkedés mértékét, nincs egyértelmű bizonyíték ideális napi bevitelük tekintetében. Kívánatos, hogy - különösen az inzulinnal kezelt - cukorbetegek elsajátítsák a szénhidrát-számolás alapjait. ${ }^{66,67,69}$ A szénhidrátforrás tekintetében előnyben részesítendők a zöldségfélék, a teljes kiőrlésű gabonából készült ételek, a gyümölcsök és a tejtermékek, míg kerülni kell a hozzáadott zsírt, cukrot vagy sót tartalmazó ételeket és italokat. Az élelmi rostok étrendi aránya cukorbetegek esetében legalább azonosnak kell lennie a nem-cukorbetegeknek ajánlott mennyiséggel. A rosttartalom növelése előnyös a szénhidrátok felszívódásának lassítása tekintetében, emellett telítő értékénél fogva csökkentheti az étvágyat és javítja a bélmüködést.

A szukróz (nádcukor, szaharóz) fogyasztása helyett más szénhidrátok izokalóriás mennyiségét ajánlott választani. Az elemi cukrot tartalmazó ételek gyors és jelentős vércukor-emelkedést okozhatnak. Azonos szénhidrátmennyiség más formában, pl. összetett szénhidrátként vagy élelmi rostokkal kiegészítve történő bevitelével a vércukorszint egyenletesebb, elhúzódóbb emelkedése érhető el. ${ }^{67}$

Ajánlott, hogy a gyümölcscukor bevitele természetes formában (gyümölcsökkel, zöldségfélékkel) történjék. Bár újabb adatok szerint a fruktóz-fogyasztás nem emeli a trigliceridszintet, ha napi mennyisége csekély (kisebb, mint az összes energiabevitel $12 \%$-a), a fruktózzal készült italok és édességek fogyasztása kerülendő, mert a fenti határ átlépésével járó többletkalóriák súlynövelő, valamint vérzsír-szintet befolyásoló hatása a keringési kockázatot fokozza. ${ }^{67}$

A zsírok étrendi arányát és a zsiradékokat tartalmazó táplálékok összetételét minden esetben egyénre szabottan, a keringési kockázat figyelembevételével célszerű meghatározni. Korábbi ajánlások előirányozták az étrend optimális telített 
(saturated fatty acid: SFA, $<10 \%$, de LDL $>2,5$ $\mathrm{mmol} / \mathrm{l}$ esetén $<7 \%$ ), többszörösen (polyunsaturated fatty acid: PUFA, $\approx 10 \%$ ), illetve egyszeresen telítetlen zsírsav (monounsaturated fatty acid: MUFA, ₹10-12\%) tartalmát, hozzátéve, hogy a szénhidrátok és a MUFA együttes aránya 60-70\% legyen. ${ }^{28}$ Újabb tanulmányok nem szolgáltattak evidenciát ezen étrendi előírások egyértelmű előnyeire, bár több vizsgálat megerősítette, hogy a MUFA-gazdag mediterrán étrend csökkenti a 2-es típusú diabetest kísérő keringési kockázatot. ${ }^{66,67},{ }^{69}$

Nincs egyértelmü bizonyíték eicosa (eicosa penthenic acid: EPA)-, illetve docosapenténsav (docosa penthenic acid: DPA) étrendi pótlásának a 2-es típusú cukorbetegek keringési eseményeit megelőző hatására. Bár az EPA, DPA, valamint az $\alpha$-linolénsav étrendi pótlása nem szolgáltatott meggyőző adatokat a 2-es típusú diabetes keringési eseményeinek csökkentésére, arányuk étrendi növelése diabeteses és nem-cukorbeteg személyeknek egyaránt tanácsolható, mivel előnyösen befolyásolják a vér lipoprotein összetételét és csökkenthetik az állapotot kísérő keringési kockázatot. Ajánlott hetente két alkalommal hal, főleg zsírban gazdag tengeri hal étrendbe illesztése. ${ }^{67}$

Dyslipidaemiával szövődött diabetesben előnyös lehet napi 1,6-3,0 gramm növényi sztanol vagy szterol fogyasztása. A növényekben található szterinek a szervezetbe jutva, receptoraikhoz történő kapcsolódásuk révén mérséklik a táplálékkal fölvett koleszterin felszívódását. A fitoszterinekkel dúsított élelmiszerek fogyasztása ezért kedvező, mert csökkenthetik a szérum össz- és LDLkoleszterintartalmát. ${ }^{67}$

Célszerű a transz-zsírsavak étrendi bevitelének csökkentése, mert mérsékelheti a szérum LDLés növelheti HDL-koleszterintartalmát. A 2-es típusú diabetest az esetek túlnyomó többségében atherogen dyslipidaemia kíséri, amelyet a szérum triglicerid, valamint kis, nagysűrűségű $\mathrm{LDL}$ koleszterin tartalmának emelkedése, s a HDLkoleszterinszint csökkenése jellemez. ${ }^{70}$ Hasonló eltérések figyelhetők meg metabolikus szindrómával társult 1-es típusú diabetesben is („double diabetes”), míg a kívánttól elmaradó glykaemiás kontroll a diabetes mindkét típusában emeli a triglicerid (és csökkenti a HDL-koleszterin) szintet. A dyslipidaemia felgyorsítja az atherogenesist, az emelkedett vércukorértékekkel együtt fokozza az oxidatív stresszt, lipidperoxidáció bekövetkeztét. A transz-zsírsavak e folyamatok további károsodását okozhatják, étrendi bejutásukat ezért a lehető legkisebb mértékűre kell szorítani cukorbeteg és nem-diabeteses személyeken egyaránt. ${ }^{67}$

$\mathrm{Az}$ étrend fehérjetartalmának egyénre szabott meghatározása célszerű. Ellentétes megfigyelések ismeretesek arról, hogy vesebetegségtől mentes cukorbetegeken az étrend fehérjetartalmának növelése (az össz-energia 20-40\%-ára) hogyan befolyásolja - javítja-e - a glykaemiás kontrollt, a vér koleszterin-, LDL-koleszterin-, illetve trigliceridtartalmát. A vizsgálatok nagyobb része nem támasztja alá a nagyobb bevitel előnyeit. ${ }^{67} \mathrm{Az}$ új nemzetközi ajánlások az étrend fehérjetartalmának $0,8 \mathrm{gramm} /$ testsúlykg/napra történő megállapítását javasolják, a vesefunkció-beszűkülés súlyosságától függetlenül. Az ennél nagyobb mértékű fehérjemegszorítás nem tanácsolható, mert érdemben nem javítja a glykaemiás kontrollt, nem mérsékli a keringési kockázatot és nem lassítja a glomerularis filtráció további romlását. ${ }^{66,67,71}$ Fontos annak ismerete, hogy 2-es típusú diabetesben a fehérjefogyasztás a vércukorszint emelkedése nélkül növeli az inzulinszekréciót, ezért magas fehérjetartalmú szénhidrátforrások használata kerülendő.

A cukorbeteg az étrendjét a szokásosan ajánlott - azaz egészséges és értékes tápanyagforrásokban gazdag - élelmiszerekből állítsa össze és ne „diétás” termékeket fogyasszon. A köztudatban keringő „diétás élelmiszer” fogalom sok félreértéshez vezetett. Ilyen jelölésű ételek választásakor gyakran feledésbe ment, hogy - a napi szénhidrát-mennyiségbe beszámítható cukorhelyettesítőkkel (pl. fruktóz, xilit, szorbit) együtt szénhidráttartalmuk egyező, sőt, akár nagyobb is lehet a „nem-diétás” azonos termékhez viszonyítva (pl. a „diétás” sörök egy része, „diétás” méz). A finomított szénhidrátokat (pl. az elemi állapotú cukrot), hozzáadott cukrot tartalmazó élelmiszerekkel és italokkal szemben a természetes alapanyagok előnyben részesítése ajánlott. ${ }^{66,67} \mathrm{Az}$ ilyen és hasonló tévedések megelőzése céljából született az Európai Parlament és Tanács határozata nyomán 2016. július 20-án hazánkban is hatályba lépett rendelet, amely a diétás/diabetikus élelmiszerek jelzést megszüntette.

Cukorbetegek számára csak mérsékelt alkoholfogyasztás tanácsolható, mert az alkoholfogyasz- 
tás fokozhatja a nem kívánt vércukoresés kockázatát, különösen inzulinelválasztást fokozó szereket vagy inzulin(oka)t kapó személyek esetében. A szervezetben jelen lévő alkohol - lebomlásáig gátolja a májban történő glikogénbontást és következményesen, a vércukoresés ellensúlyozását szolgáló hepatikus glukózkibocsátást. ${ }^{67}$ Tanácsolható ezért, hogy a cukorbeteg - ha kívánja - elsősorban a fóétkezésekhez kapcsolódóan fogyaszszon alkoholt. Cukorbeteg nők számára naponta legfeljebb 1, férfiak részére 2 egység fogyasztása tanácsolható. ${ }^{66,67} \mathrm{~A}$ WHO korábban meghatározta a különféle szeszes italok egy egységnyi menynyiségét, ami 1-1,5 dl bornak, $3 \mathrm{dl}$ sörnek, 3 cent töményitalnak, azaz $\approx 15$ gramm tiszta alkoholnak felel meg. ${ }^{28}$

Napi 1-3 - babkávéból készült - eszpresszókávé, illetve 2-4 csésze tea fogyasztható. A koffein, tein nem emeli a vércukor szintjét.

Vitamin-, ill. ásványisó-készítmények kedvező hatása nem igazolt. Antioxidánsok rutinszerű adása nem ajánlott - szövődmények megelőzésére/késleltetésére gyakorolt hatásuk eddig nem igazolódott -, megadózisok tartós adása ártalmas.

\section{Ajánlás 11 \\ A glykaemiás index fogalmának elsajátíttatása cél- szerü, mert az segítheti az anyagcserekontroll javu- lását. („C")}

A magas glykaemiás indexszel rendelkező ételek gyorsabb felszívódásuk révén korai vércukor-emelkedést okoznak. Azonos tápértékű élelmiszerek, élelmi anyagok alacsony glykaemiás indexű változatainak fogyasztása vagy alacsony glykaemiás indexű étel választása mérsékelheti az étkezés utáni vércukorszintet. ${ }^{67}$

\section{Ajánlás 12 \\ Energiamentes és alacsony energiatartalmú édesí- tőszerek használata ajánlott, mert ezek csökkenthe- tik a napi szénhidrát- és energiafelvételt. (,B")}

A korábbi - nevezéktanilag is összekeverhető cukorhelyettesítő és cukorpótszer, illetve természetes és mesterséges édesítőszer csoportok helyett ma energiamentes (étrendi beszámítás nélkül fogyasztható) és étrendbe beszámítandó csoportokat különböztetünk meg. Az előbbiek egy része szintetikusan előállított (szacharin, ciklamát, aceszulfám-K, aszpartám, szukralóz), más része természetben előforduló (sztívia, édes fehérjék: taumatin, neoheszperidin, monellin, mabinlin stb., többségük nincs kereskedelmi forgalomban). A beszámítást nem igénylő változatok fehérjetartalmuk révén - csekély - energiát tartalmaz(hat)nak. Az étrendbe beszámítandó származékok a fruktóz és a tagatóz kivételével - amelyek elemi cukrok - cukoralkoholok (xilit/ol/, laktit/ol/, szorbit/ol/, mannit/ol/, maltit/ol/, isomaltit/ol/). Valamennyi esetében meghatározták tanácsolható napi adagjukat (adviseable daily intake: ADI), amely dózis alatti mennyiségben történő használatuk egészségkockázat nélkül folytatható.

E szerek különböznek egymástól édesítőerejükben, esetleges mellékízt okozó hatásukban, valamint hőstabil (ízhatását melegítést követően is megtartó: ciklamát, aceszulfám-K), illetve hőlabilis természetükben (szacharin, aszpartám, szukralóz). Az aszpartám fényérzékeny is, $\mathrm{s}$ a lejárati időn túl elbomlik (a felhasználásával készült termékek édes ízüket elveszítik). Ez utóbbi vegyület fenilalanin-származék, fenilketonuriában szenvedők ezért nem használhatják. A forgalomban lévő mesterséges édesítőszerek (újabb elnevezéssel: intenzív édesítőszerek) kisebb része egykomponensű, többségük azonban kombináció, amelyek élvezeti, hasznosíthatósági sajátosságai az összetevők függvényében változnak. ${ }^{72}$

\subsection{Fizikai aktivitás}

\author{
Ajánlás 13 \\ Javasolt, hogy minden cukorbeteg felnőtt heten- \\ te legalább 150 percnyi közepes intenzitású aerob \\ mozgást folytasson (a maximális szívfrekvencia \\ 50-70\%-ával), lehetőség szerint napi rendszeres- \\ séggel. („, $A ")$
}

A rendszeres testmozgás javítja a vércukorszintet, kedvezően befolyásolja a keringési kockázati tényezőket, továbbá a diabetes előállapotaiban csökkenti a diabetesbe történő konverziót. A teherbíró képességhez és az edzettségi állapothoz igazodó fizikai tevékenység ezért az „intenzív életmódkezelés" része kell, hogy legyen. A glykaemiás kontrollt, valamint a keringési kockázat mutatóit a megfelelő étrend és a fizikai aktivitás külön-külön 
is kedvezően érinti, együttes alkalmazásuk hatékonysága azonban kifejezettebb.

Több vizsgálat igazolta az életmódba épített fizikai aktivitás anyagcserét javító és keringési kockázatot csökkentő természetét: a glykaemiás kontroll javulása szorosan korrelált a fizikai terhelés mértékével és időtartamával A fizikai tevékenység eredményezte többlet-energiaigény elősegítheti a testsúly csökkenését is. ${ }^{66,73,74}$

Minden egészséges felnőttet, beleértve a cukorbetegeket is, ösztönözni kell, hogy csökkentsék a tétlenséggel töltött időt. Helyes, ha a felnőtt, mozgásában nem korlátozott cukorbeteg szabadidejében nem tölt egyfolytában 90 percnél hosszabb időt valamilyen mozgástevékenység nélkül. ${ }^{66}$

Ellenjavallat hiányában kívánatos, hogy felnőtt cukorbetegek legalább heti 2 alkalommal rezisztencia típusú terhelést is végezzenek. A fizikai tevékenység intenzitását, időtartamát, formáját és gyakoriságát egyénre szabottan kell meghatározni. Különböző terhelési módozatok ismeretesek. $\mathrm{Az}$ állóképességi edzés során folyamatos, ciklikus, az aerob tartományban maradó, nagy izomcsoportokat igénybevevő sportok jönnek szóba (gyaloglás, gyors séta, kerékpározás, úszás, tánc, vízi torna, szobakerékpár). A statikus mozgás nem abszolút kontraindikált, de csak egyénre szabottan építhető be a mozgáskezelésbe. A rezisztenciatréning az izomerő növelését, ill. a testösszetétel változását célozza, az alapanyagcsere megemelésével nagyobb energiafelhasználást biztosít. Folytatható stretching, ill. javasoltak lehetnek mindennapi mozgások (séta, lépcsőzés, házkörüli munka végzése). Az artériás értorna a perifériás erek szűkületének megelőzésére célzottan alkalmazott gyakorlatok végzését jelenti. ${ }^{73,74}$

Helyes, ha a mozgásprogram megkezdése előtt a cukorbeteg konzultál orvosával, illetve gyógytornásszal. Az előzetes állapotfelmérésnek ki kell terjednie az általános állapot, különös tekintettel a cardiopulmonalis terhelhetőség megítélésére, valamint a diabetes-specifikus szempontokra (esetleges szövődmények feltérképezése, különös tekintettel a mozgásszervek állapotára, neuro-, retino-, osteoarthropathia fennállására).

A mozgásprogram alatt/után kiemelten fontos az anyagcsere-monitorozása, lehetőség szerint vércukor-önellenőrzés végzése. Az antidiabetikus gyógyszeres kezelést és/vagy inzulindózist a moz- gáshoz kell igazítani a vércukoresés elkerülése érdekében. Ha az edzés előtti vércukorérték <6,5 $\mathrm{mmol} / \mathrm{l}$, akkor terhelés előtt ( $\mathrm{s}$ hosszabb fizikai aktivitás során terhelés közben is) javasolt plusz szénhidrát bevitele. Ketózis (acetonuria) vagy magas vércukorérték (általában $>15-16 \mathrm{mmol} / \mathrm{l}$ ) esetén a fizikai aktivitás halasztása javasolt. Az inzulinhatás csúcsán végzett fizikai aktivitás hypoglykaemiát okozhat. Inzulinkezelésben nem részesülő betegeknél a terheléssel összefüggő hypoglykaemia előfordulása nagyon ritka. ${ }^{28,73,74}$

\subsection{Gyógyszeres kezelés}

\section{Az 1-es típusú diabetes mellitus antihyperglykaemiás kezelése}

Az 1-es típusú cukorbetegek inzulinnal kezelendők. A tartós inzulinkezelés minden formáját kezelési rendszerben kell alkalmazni, amely magában foglalja az inzulininjekciók számát, a beadás időpontját, az étkezések számát, időpontját és javasolt szénhidráttartalmát, valamint az étkezések inzulinbeadáshoz történő illesztését.

Lehetőség szerint a betegség felfedezésétől kezdődően normo- vagy euglykaemia, az egészséges egyének vércukorszintjét leginkább megközelítő beállítás elérésére és fenntartására kell törekedni. Ez az anyagcserehelyzet alkalmas a cukorbetegség késői szövődményei kialakulásának késleltetésére, kivédésére, egyes, már kialakult szövődmények progressziójának lassítására, sőt megállítására.

$\mathrm{Az}$ inzulinkezeléssel többnyire törvényszerűen együtt járó anyagcsere-labilitásra tekintettel csupán a vércukor céltartományon belül tartására törekedhetünk: ez éhgyomorra elfogadható esetben 4,0 és 6,5, étkezés után 90-120 perceel pedig 6,0 és $8,0 \mathrm{mmol} / 1 \mathrm{közötti} \mathrm{értékeket} \mathrm{jelent.} \mathrm{Az} \mathrm{éjsza-}$ kai hypoglykaemia elkerülése céljából a lefekvés előtti vércukorértéket kívánatos kicsit magasabban, 6,0-8,0 mmol/l között tartani. Amennyiben a mért esetek legalább $70 \%$-ában a vércukor a fenti céltartományokon belül mozog, és a $\mathrm{HbA}_{1 \mathrm{c}}$ szintje az egyénileg megállapított célértéken $(6,0-8,0 \%$ közötti céltartományon belül a kockázat nélkül elérhető legalacsonyabb értéken) van, a glykaemiás kontroll jónak tekintendő.

Az 1-es típusú diabetes kórisméjének felállításakor az inzulinkezelés abszolút indikált. Ugyan- 
így abszolút indikált az inzulin adagolása a bármely okból létrejövő diabeteses ketoacidosisban és nem-ketotikus hyperosmolaris állapotban.

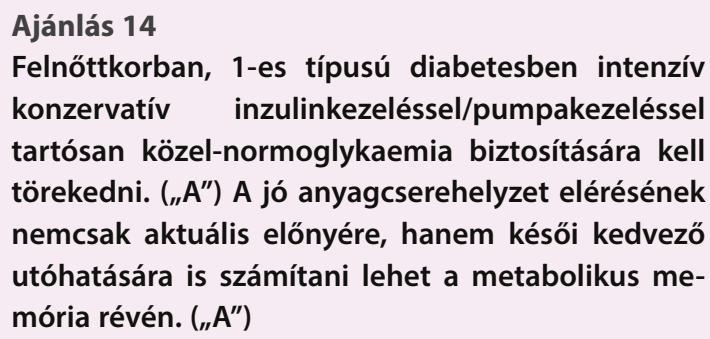

A DCCT adataiból 1993 óta tudjuk, hogy a tartósan jó anyagcserehelyzetre való törekvés (alacsonyabb $\mathrm{HbA}_{1 \mathrm{c}}$-érték biztosítása) számottevően csökkenti a microangiopathiás szövődmények kialakulásának és progressziójának kockázatát. ${ }^{75}$ $\mathrm{Ez}$ a ténykedés rövid távon szerény mértékben, hosszabb távon bizonyítottan csökkenti a macroangiopathiás szövődmények kialakulásának és progressziójának kockázatát is. ${ }^{76} \mathrm{~A}$ jobb anyagcserehelyzetnek a micro- és macroangiopathiás szövődmények progresszióját előnyösen befolyásoló hatása az intervenció után évtizedekkel is kimutatható, ${ }^{77}$ a DCCT-EDIC vizsgálatban megfigyelt jelenséget az irodalom metabolikus memóriának nevezi. . $^{7,79}$

Az intenzív konzervatív inzulinterápia (ICT) a felnőtt 1-es típusú cukorbetegek döntő többsége számára ajánlott kezelési forma. Az intenzív inzulinkezelés többkomponensủ kezelési rendszer, melynek célja az egyes étkezések, valamint az étkezés-mentes napszakok ideális inzulinszükségletének biztosítása, napjában többször adott inzulin segítségével. Végrehajtásában egyaránt részt vesz a beteg és az őt irányító egészségügyi csapat. A rendszer elengedhetetlen része a rendszeres vércukor-önellenőrzés, valamint azon ismeretek megtanítása és elsajátítása, amelyek lehetővé teszik egy előzetesen beállított alaprendszer életstílusnak és élethelyzeteknek megfelelő, rugalmas alkalmazását. A betegnek tudnia kell inzulinját tervezett mozgásának, étkezési rendjének megfelelően előre szabályozni. Ismernie kell teendőit különböző élethelyzetekben. Az intenzív inzulinkezelés ennek megfelelően javítja az életminőséget, biztosítja az egészséges életmódot folytató nem cukorbeteg egyén szokásaihoz hasonló napi ritmus követését.
Az intenzív inzulinkezelés alkalmazásának feltételei

- Személyi feltételek:

- a kezelést irányító team: a diabetológus orvos, az oktatónővér, a dietetikus, a pszichológus,

- megfelelő ismeretek az ICT alapjairól, alkalmazásáról,

- a beteg motiválása,

- oktatás csapatmunkában, a beteg (és családja) pszichés támogatása mellett, probléma esetén a team valamelyik tagja - legalább telefonon - mindig elérhetô legyen a csapat egyenrangú tagjaként kezelt beteg számára.

- Tárgyi feltételek:

- a vércukor-önellenőrzés eszközei,

- a beteg motivációját és flexibilis életvitelét segítő inzulint adagoló eszközök,

- a megfelelő inzulinkészítmények

Az ICT alkalmazásának korlátai is vannak. Meggondolandó az ICT alkalmazása olyan betegek esetében, akik alkalmatlanok a szükséges tudásanyag megtanulására, alkalmazására, nem hajlandók vagy nem képesek rendszeres vércukor-önellenőrzésre. Kérdéses az ICT használata, ha az egyén azonos rend szerint él, életvitele stabil, vércukor- és $\mathrm{HbA}_{1 c}$-értékei elfogadhatók és így az intenzív kezeléstől sokoldalú előny nem várható.

Az inzulinkezelés kockázatát a hypoglykaemia és a testsúlygyarapodás jelenti. Lokális szövődmény (allergia, infekció) jelentkezése igen ritka. Az intenzív inzulinkezeléssel elért $\mathrm{HbA}_{1 c}$-érték inverz összefüggést mutat a hypoglykaemia kockázatával.

Az orális antidiabetikumok az 1-es típusú diabetes kezelésében alárendelt jelentőségüek és csak az inzulinkezelés kiegészítéseként, jelenleg off label indikációval alkalmazhatók. Amennyiben klinikai adatok a 2-es típusú diabetes fenotípus-jegyeire utalnak - ami hazai adatok szerint is gyakori az 1-es típusú diabetesben szenvedőkben ${ }^{80}$ - metformin adása szóba jön, amely az inzulinigény csökkenését is eredményezheti. A postprandialis vércukor-emelkedés mérséklésére, sőt, a fizikai aktivitással összefüggő vércukor-ingadozások csökkentésére ${ }^{81}$ az akarbóz 1-es típusú betegekben is szóba jöhet, noha napjainkban ilyen esetben inkább gyors hatású inzulinanalógot választunk. 
Ajánlás 15

Az 1-es típusú cukorbetegek intenzív inzulinkezelési rendszerében az inzulinanalógokat előnyben kell részesíteni a humán inzulinokhoz viszonyítva. $\left({ }_{\text {, }} \mathrm{A}^{\prime \prime}\right)$

Az ICT rendszer felépíthető humán inzulinnal és inzulinanalógokkal is. A kevert (hibrid) kezelési rendszer (humán inzulin és inzulinanalóg együttes alkalmazása) kerülendő. Mind a gyors hatású, mind a bázisinzulin-analógok kedvezőbbek a megfelelő humán inzulinokhoz viszonyítva a felnőttkorú 1-es típusú cukorbetegek számára, ezért azok inkább preferálandók. A hosszú hatású, napjában egyszer (glargin, bioszimiler glargin, glargin U300, degludek), ill. egyszer vagy kétszer adott inzulinanalóg (detemir) + napjában többször adott gyors hatású inzulinanalóg adása jobb beállítást eredményezhet, és csökkenti a hypoglykaemia kockázatát, mint a hagyományos, humán bázis-bólus kezelési rendszer. $82,83,84,85,86,87,88$

\section{Kezelés humán inzulinnal}

1-es típusú diabetesben szenvedők tartós kezelésére - az inzulinanalógok elterjedése óta - jelentősen háttérbe szorult kezelési forma.

Ha az 1-es típusú cukorbetegnek még van bizonyos mértékű saját inzulinszekréciója, akkor a napjában egyszer alkalmazott humán, intermedier, NPH-inzulin lefekvés előtt, az étkezések előtt adott három gyors hatású reguláris humán inzulinnal kombinálva biztosíthatja az anyagcsere-egyensúlyt. Ilyenkor a főétkezéseket megelőzően beadott gyors hatású reguláris humán inzulin (a még meglévő saját inzulinszekrécióval együtt) biztosítja az adott - 5-7 órás - napszak bazális inzulin szükségletét is (pl. reggel 8-14 NE, délben 6-12 NE, késő délután 8-14 NE gyors hatású humán inzulin, lefekvéskor adott 8-14 NE intermedier humán inzulin).

Napjában kétszer - reggel és lefekvés előtt egyaránt sor kerülhet intermedier humán inzulinkészítmény alkalmazására. Ilyenkor az étkezések előtt kevesebb gyors hatású reguláris humán inzulin adására szorul a beteg (pl. reggel 6-10, délben 4-6, késő délután 8-12 NE gyors hatású humán inzulin, valamint reggel 10-16 NE, illetve lefekvés előtt 8-14 NE intermedier humán inzulin).
Kezelés inzulinanalógokkal

Gyors hatású inzulinanalógok

A jelenleg Magyarországon is forgalomban levő, gyors hatású inzulinanalógok, a lizpro-inzulin, az aszpart-inzulin, ill. a glulizin inzulin reguláris gyors hatású humán inzulin helyett történő alkalmazása az alábbi esetekben javasolható ICT rendszerekben:

- Amennyiben a korábban alkalmazott ICT során gyors hatású humán inzulin adása mellett nem volt biztosítható megfelelő anyagcserehelyzet $\left(\mathrm{HbA}_{1 \mathrm{c}}<8,0 \%\right)$, vagy a postprandialis vércukorérték ismételten meghaladta a 10,0 mmol/l értéket; vagy dokumentáltan gyakori, tünetekkel járó hypoglykaemia jelentkezett;

- A betegség remissziós fázisa esetén a főétkezések előtt adva, lefekvéskor adott bázisinzulinnal kombinálva;

- Jelentős, egyéb módszerekkel nem befolyásolható postprandialis vércukor-emelkedés esetén, napi egy vagy kétszer adagolt hosszú hatástartamú inzulinanalóg mellett.

- Mivel ezen inzulinok adása esetén közti étkezés elvileg nem szükséges, így az étkezések számának csökkentése - testsúlycsökkentési célzattal vagy rendszertelenebb életmód miatt - relatív indikációt képez.

Gyors hatású inzulinanalógok adása mellett az étkezést követő vércukor-emelkedés jóval kisebb mértékű, a hypoglykaemiák száma csökken, a megfelelő humán inzulinokhoz viszonyítva. A diabetes remissziós fázisa kivételével gyors hatású inzulinanalógot csak megfelelő bázisinzulinnal (1-es típusú diabetes esetén napjában egyszer adott glarginnal, bioszimiler glarginnal vagy glargin U300-zal, degludekkel ill. egyszer vagy kétszer adott detemirrel) együtt lehet hatásosan alkalmazni.

Hosszú hatástartamú inzulinanalógok

Amennyiben az ICT részeként hosszú hatástartamú inzulinanalógot (glargin, bioszimiler glargin, glargin U300, ill. detemir) alkalmazunk, akkor az általában ugyancsak este, lefekvés előtt adott hosszú hatású inzulinanalóg az alkalmazott teljes inzulinmennyiség kb. 50\%-át teszi ki. Hosszú hatástartamú inzulinanalóg mellé gyors hatású inzulinanalógot adunk a prandialis inzulinszükség- 
let biztosítása érdekében, alapesetben napjában háromszor, a dózist igazítva az aktuális étkezés szénhidráttartalmához.

$\mathrm{Az}$ először forgalomba került hosszú hatástartamú inzulinanalógok (glargin, detemir) - humán NPH-inzulinhoz viszonyítva - a betegek számára jobb életminőséget biztosítottak, s alkalmazásuk során kevesebb - főleg éjszakai - hypoglykaemia fordult elő. A később elérhetővé vált hosszú hatástartamú inzulinanalógok (degludek, glargin U300) előnyét glarginnal szemben tesztelték, a biohasonló (bioszimiler) glargin hasonlóságát értelemszerűen az originális glarginnal összehasonlítva vizsgálták.

A degludek inzulin alkalmazásának előnye a csúcsmentes, 24 órát meghaladó hatástartam, melynek révén tovább csökkenthető az éjszakai hypoglykaemiák kockázata, további előny a rugalmas, napszaktól független beadás lehetősége. A degludek inzulin mellett alacsonyabb az éjszakai hypoglykaemia kockázata és nagyobb mértékű az éhomi vércukorszint csökkenése glarginhoz képest 1-es típusú cukorbetegek bázis-bolus kezelése során. ${ }^{89,90}$ Degludek inzulin mellett alacsonyabb az intra-individuális variabilitás glarginhoz képest 1-es típusú cukorbetegekben. ${ }^{90}$

A glargin U300 inzulin adásának előnye, hogy a glarginhoz képest 24 órán túli hatást és kisebb variabilitást biztosít. Így a hypoglykaemia kockázata csökkenthető. ${ }^{11}$ A glargin U300 inzulin glykaemiás hatékonysága a glarginéval megegyezik. ${ }^{92,93}$ A glargin U300 inzulin adása mellett kisebb mértékű a testsúlynövekedés, mint glargin adásakor. ${ }^{92}$

A glargin inzulin és a bioszimiler glargin inzulin glykaemiás hatékonysága és biztonságossága között érdemi különbség nem mutatható ki. ${ }^{94,95}$

A testsúlygyarapodás detemir mellett kevésbé kifejezett, egyes esetekben szerény testsúlycsökkenés is remélhetö. ${ }^{96}$

Az inzulinkezelés, különösen az ICT beállítása és alkalmazása során ismernünk kell azokat a részben a betegtől független, részben a beteg szokásain, viselkedésén alapuló - tényezőket, amelyek a kezelést befolyásolhatják. Ilyen - betegtől független - kezelést befolyásoló esemény pl. a meteorológiai fronttevékenység. A kettős fronthatás vagy a labilis melegfront hypoglykaemiához, egyes hidegfrontok hyperglykaemiához vezethetnek. Ismerni kell a menstruációs ciklus inzulinigényt módosító hatását (a premenstruumban az inzulinigény jelentősen növekszik, a peteérés idején csökken), a hajnali jelenség (dawn phenomenon), délutáni-alkonyi (dusk phenomenon) jelenség vagy a szezonális inzulinigény-változások hatását az adott betegben.

- A hajnali jelenség kezelésében általában hoszszú hatástartamú inzulinanalóg adása javasolt, de alternatívaként szóba jön humán inzulin napi ötszöri adása (föétkezésekhez illetve 22:00 és 03:00 órakor - amennyiben a beteg ezt vállalja), illetve inzulinpumpa alkalmazása is.

- Somogyi-hatás: hypoglykaemiás vagy ahhoz közeli - esetenként meg nem érzett - vércukorértékek mintegy 6 óra múlva és 12-72 órán keresztül tartó ellenregulációt válthatnak ki a szervezetben, jelentős hyperglykaemiás értékeket eredményezve. Ha nem ismerjük fel e magas vércukorértékek okát, vagy nem megfelelően (túl)korrigáljuk azokat, az inzulincsökkentés elmaradása vagy az inzulinemelés jelentős labilitáshoz vezet.

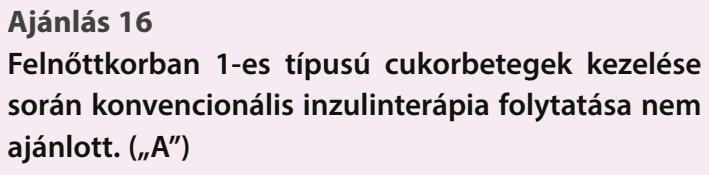

A konvencionális inzulinkezelés - amelyen ma a napi kétszeri inzulinadást értjük - az 1-es típusú diabetes kezelésében teljesen háttérbe szorul, minthogy a jellemzően nagy napi vércukor-ingadozások kiküszöbölésére, a kívánt normoglykaemia biztosítására nem alkalmas. ${ }^{97}$ Bizonyított, hogy az ICT-hez viszonyítva tartósan rosszabb anyagcserehelyzetet biztosít, ami az idült szövődmények kialakulásának fokozott kockázatával jár. ${ }^{75}$

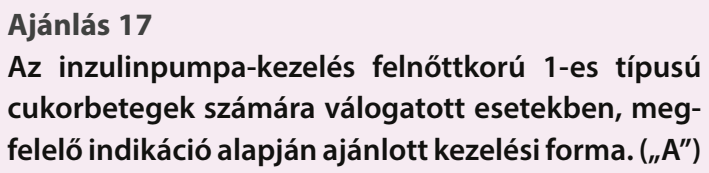

$\mathrm{Az}$ inzulinadagoló készülék (pumpa) használata világszerte elfogadott, speciális, intenzív kezelési mód. Hazánkban közel 2200 beteg, döntően gyermek- és serdülőkorú alkalmazza, de használata válogatott esetekben, megfelelő indikáció alapján szóba jön felnőttkorú 1-es típusú cukorbetegek körében is. 
$\mathrm{Az}$ inzulinpumpa elemmel működő elektromechanikus szerkezet, amely tartállyal rendelkezik az inzulinpatron számára, és folyamatosan adagol gyors hatású inzulinanalógot a bőr alatti szövetbe. Rendkívül fontos leszögezni azt, hogy a nagyon hatékony technikai összetevők mellett az inzulinpumpa nem automatizált eszköz. Mind a bazális, mind a bólus inzulin beadásának mennyiségét a beteg döntésétől függően, az önellenőrzés eredményei alapján kell meghatározni. A kanült 2-4 naponta cserélni kell. ${ }^{98}$

Az inzulinpumpa-kezelés előnyei:

- kevesebb és kevésbé súlyos hypoglykaemia fordul elö,

- a vércukorértékek variabilitása csökken,

- a terhesség korai szakában a vércukorértékek és a szénhidrát-anyagcsere könnyebben kezelhető (pl. hyperemesis estén),

- az inzulinhatás reprodukálása könnyebb,

- az inzulin-hatásprofil 24 órás változásának élettanihoz közelítő megvalósítása lehetséges,

- életminőséggel kapcsolatos előnyök

- flexibilisebb életmód (a napi aktivitások megszervezése, nem várt események pl. fizikai aktivitás, több étkezés),

- kevesebb inzulin-injekció,

- burn-out szindróma esetén a beteg számára segítséget jelent.

$\mathrm{Az}$ inzulinpumpa-kezelés társadalombiztosítási támogatással megvalósítható indikációja felnőttkorban (a gyermekkori kezelés indikációit és a kivitelezés körülményeit a felsorolás nem tartalmazza):

Legalább három éve 1-es típusú diabetes mellitusban szenvedő betegek számára rendelhető, ha

- $\mathrm{HbA}_{1 c}$-értéke ismételten $>7,0 \%$, prekoncepcionális gondozás során $>6,5 \%$, vagy

- napi vércukor-ingadozása jelentős $\quad(\geq 10,0$ $\mathrm{mmol} / \mathrm{l})$, vagy

- hajnali jelenség igazolható (reggeli éhomi vércukor ismételten $>8,0 \mathrm{mmol} / \mathrm{l}$ ), vagy

- havonta legalább 3 alkalommal észlelhető klinikai tünetekkel járó hypoglykaemia, vagy

- hypoglykaemia-érzet csökkenése vagy elvesztése dokumentálható, vagy

- súlyos hypoglykaemia (vércukor $<3,0 \mathrm{mmol} / \mathrm{l}$ ) jelentkezik legalább 1 ízben 6 hónap alatt.

Ismételt rendelés esetén:

- az utolsó fél évben mért $\mathrm{HbA}_{1 c}$-értékek átlaga $<8,0 \%$, és
- az utolsó fél évben mért napi vércukor-ingadozás kisebb, mint a pumpakezelés megkezdése előtti érték, vagy

- a hypoglykaemiás epizódok száma csökkent a pumpakezelés előtti időszakhoz viszonyítva, vagy

- a beharangozó tünetek nélküli hypoglykaemiák száma csökkent a pumpakezelés előtti időszakhoz viszonyítva.

A pumpakezelés válogatott esetekben, megfelelő indikáció alapján folytatható. Nem ajánlott a pumpakezelés:

- súlyos fogyatékosság fennállásakor (érzészavar, alapvető kézügyesség hiánya, a véralvadás zavarai stb.),

- pszichés ellenállás esetén: a diabetes tényének elutasítása, az önellenőrzés képtelensége vagy elutasítása,

- ha rossz vagy nem elegendő az együttmüködés a gondozó csoport és a páciens között,

- társuló súlyos pszichiátriai kórképek esetén,

- a szociális támogatás (család, barátok) bizonytalansága; analfabétizmus esetén.

Napjainkban pumpainzulinként gyors hatású inzulinanalógok használatosak. Aszpart-inzulin mellett ritkább a pumpaelzáródás és az indokolatlan hyperglykaemiás epizódok előfordulása. ${ }^{99,100}$

Az inzulinpumpa hazánkban pumpaközpontokban áll a betegek rendelkezésére, a készülék beszerzése társadalombiztosítási támogatásban részesül. Az inzulinpumpa „kihordási ideje” 4 év, az újrarendelés akkor részesül társadalombiztosítási támogatásban, ha a pumpakezelés eredményességét megadott paraméterek igazolják.

\section{Ajánlás 18 \\ A pancreatogen diabetes kezelése során inzulinte- rápia választandó. „(E”)}

A felnőttkorban kialakuló diabetes - hazánkban nem túl ritkán - pancreatogen eredetű is lehet. Pancreas-betegség okozta diabetes esetén az első kezelési lépés az adekvát diéta - amennyiben az alkoholos eredet egyértelmű, teljes absztinenciát javasolva. Figyelembe véve a béta-sejtek fennálló és várható lézióját, a diéta elégtelensége esetén orális terápia helyett idejekorán inzulinkezelést kell kezdeni. Mivel a táplálék felszívódása kiszámíthatatlan, az állapot labilis, így a fóétkezések előtt adott gyors hatású in- 
zulin és lefekvéskor adagolt bázisinzulin rendszer a választandó, rendszeres önellenőrzés mellett. Terápiás törekvéseinket a hasnyálmirigy-enzimek megfelelő szubsztitúciójával kell kiegészíteni. ${ }^{101}$

\section{A 2-es típusú diabetes mellitus antihyperglykaemiás kezelése}

A 2-es típusú cukorbetegek döntő hányada az életmód-terápia mellett per os adható gyógyszeres kezelést is igényel, amelyek egy része hosszabb ideje ismert és alkalmazott, más része az utóbbi idők fejlesztésének eredménye. A betegek egy részénél a kezelés az inzulint is magában foglalja. Napjainkban az injektábilis, nem-inzulinszerű készítmények (GLP-1-mimetikumok) a kezelés új lehetőségét jelentik. Gyakori, hogy a monoterápiás gyógyszeres kezelés nem biztosít megfelelő anyagcserekontrollt, ilyenkor kombinációs kezelés megkezdésének van helye.

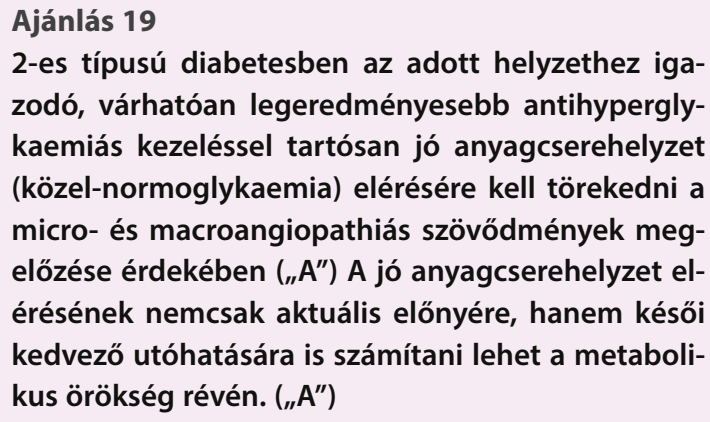

Legelőször a UKPDS igazolta, hogy újonnan felismert 2-es típusú cukorbetegek körében az intenzív kezeléssel elért jobb anyagcserehelyzet (vs. konvencionális [leginkább csak diétás előírásokból álló] kezelés) csökkenti a microangiopathiás szövődmények (retino-, neuro- és nephropathia diabetica) kialakulását és progresszióját. A vizsgálat randomizált periódusában a macroangiopathiás szövődmények alakulása terén egyértelmű csökkenést nem lehetett igazolni. ${ }^{102}$ A tanulmány zárását követő, 10 évre terjedő obszervációs adatgyűjtésből azonban kiderült, hogy a korai jó anyagcserehelyzet késői kedvező utóhatására is számíthatunk, s ez már a macroangopathiás szövődmények és a mortalitás statisztikailag értékelhető csökkenésében is megnyilvánult. A jelenséget metabolikus örökség névvel illették az irodalomban, ami szélesebb értelemben vaszkuláris memóriának is nevezhető. ${ }^{103,104,105} \mathrm{Az}$ ADVANCE vizsgálat a gliclazid-alapú terápiával elért jobb anyagcserehelyzet vs. standard kezeléssel elért szerényebb glykaemiás kontroll hatását vizsgálta. ${ }^{106}$ Igazolható volt, hogy a jobb anyagcserehelyzet preveniálja a microangiopathiás szövődmények kialakulását, az ADVANCE-ON utánkövetés ${ }^{107}$ eredményeiből az is kiderült, hogy késői előnyös hatással lehet számolni a veseszövődmények alakulása terén (metabolikus memória effektus). Hasonló kedvező memória-hatást regisztráltak a szemészeti szövődmények terén az ACCORD vizsgálat ${ }^{108}$ utánkövetése során az ACCORDION vizsgálatban is. ${ }^{109}$

Kezelés nem-inzulintermészetű vércukorcsökkentőkkel 2-es típusú diabetesben

A 2-es típusú cukorbetegség vércukorcsökkentő kezelése szekvenciális természetű. Egymásra épülő kezelési lépésekből áll, amely mindkét irányban, a gyógyszerelés bővítése („felépítő” kezelés) és csökkentése („leépítő” kezelés) irányában is történhet. Korábbi gyakorlatunkban nem tettünk különbséget a tekintetben, hogy újonnan kezelésbe/gondozásba kerülő, avagy már kezelt/gondozott személy antidiabetikus terápiájának tervezése-e a feladat, ${ }^{4,28}$ e téren a hatályos nemzetközi útmutatások sem egységesek. ${ }^{5,30,31} \mathrm{~S}$ bár a kezelés alapelvei mindkét esetben lényegében azonosak, a széles gyógyszerválasztékot, valamint a felismeréstől kezdve célértékre történő kezelés jelentőségét szem előtt tartva, indokoltnak látszik a kezelési irányelveket e szempont szerint különválasztani.

A heveny anyagcsere-kisiklással járó esetek (5. táblázat) kivételével az újonnan felismert 2-es típusú cukorbetegség kezelésének első lépése a helyesen felépített életmódkezelés. ${ }^{4,5,28}$

\section{5. táblázat. A heveny anyagcsere-kisiklás formái 2-es típusú diabetesben}

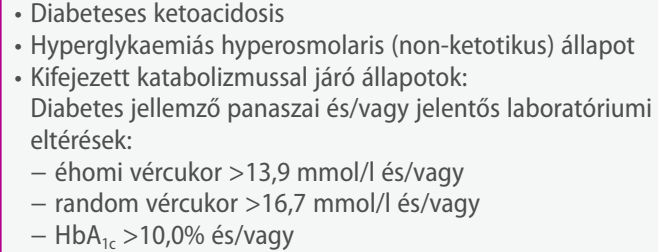

- ketonuria 
Ennek az orvosi táplálkozásterápia és életmódba épített - napi gyakoriságú - fizikai aktivitás mellett integráns része az érintett személy részletes tájékoztatása betegségéről, a kezelés sikeréhez szükséges együttműködése és önmenedzselése jelentőségéről, valamint lehetőségeiről (páciensedu- káció)., ${ }^{4,2}$ Amennyiben a glykaemiás célérték az életmódkezelés önmagában történő alkalmazásával 3 hónap elteltével sem teljesül, a $\mathrm{HbA}_{1 \mathrm{c}}$-értékkel jellemzett anyagcserekontroll függvényében orális monoterápia, kettős vagy hármas antidiabetikum-kombináció bevezetése szükséges (3. ábra).

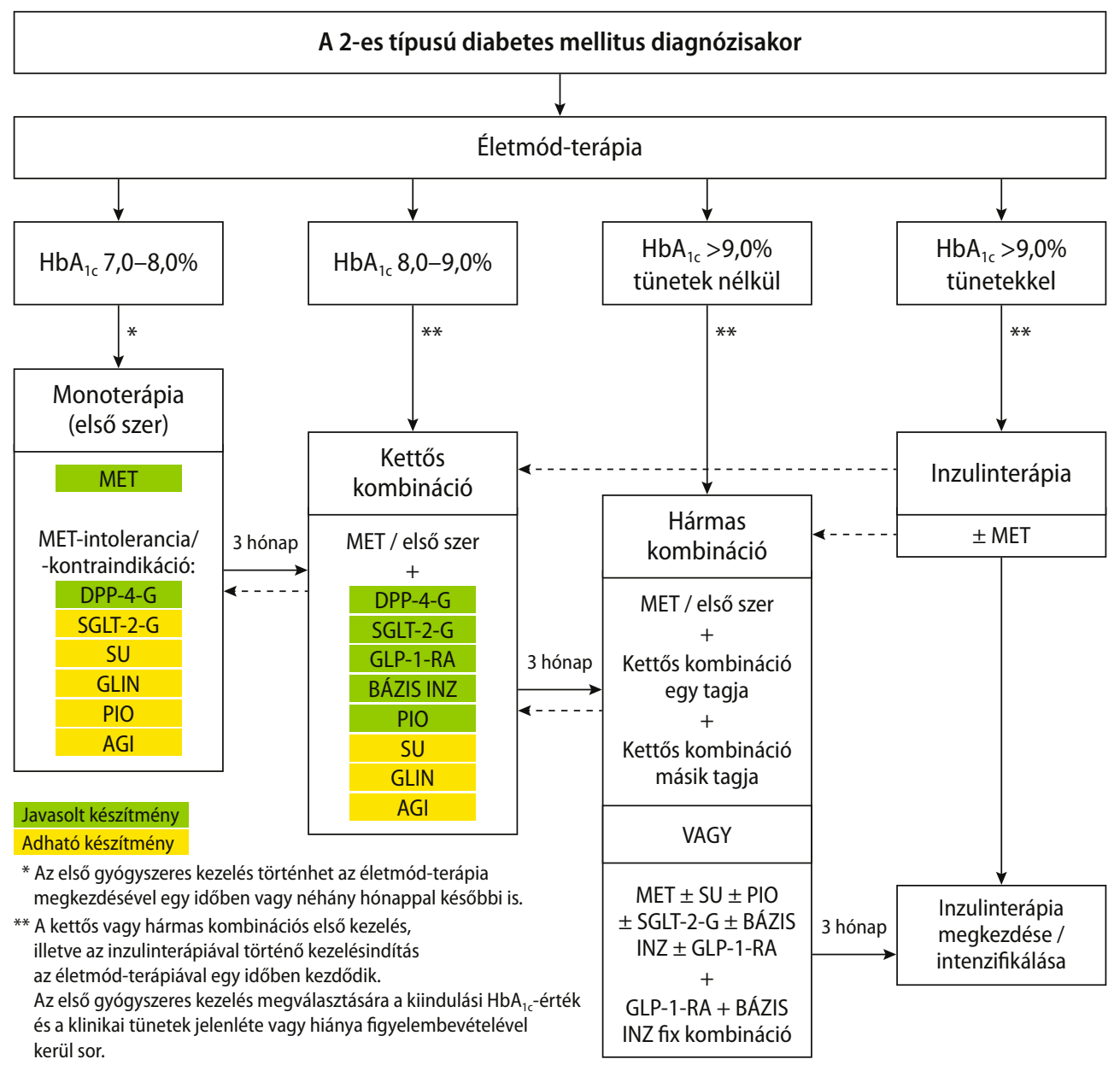

AGI: alfa-glukozidáz-inhibitor (akarbóz); BÁZIS INZ: bázisinzulin; DPP-4-G: dipeptidilpeptidáz-4-gátló; GLIN: glinid (prandialis glukózregulátor), GLP-1-RA: GLP-1-receptoragonista, MET: metformin, SU: szulfanilurea, PIO: pioglitazon, SGLT-2-G: nátrium-glukóz-kotranszporter-2-gátló

3. ábra. Szakmailag megalapozott terápiás lépések az újonnan felismert 2-es típusú diabetes mellitus kezelésekor A kezelési célérték általában $\mathrm{Hb} \mathrm{A}_{1 c}<7,0 \%$ (kezelési céltartomány 6,0-8,0\%). A következő kezelési lépcsőre való áttérést akkor kell megfontolni, ha a beteg az adott kezelés mellett nem érte el az egyénileg megállapított célértéket, általában 3 hónapig tartó kezelés során. A kezelési rendszerekben visszafelé is lehet haladni, ha azt klinikai körülmények indokolják.

GLP-1-RA és DPP-4-gátló együttadása kerülendő!

SU és GLIN együttadása kerülendő! 


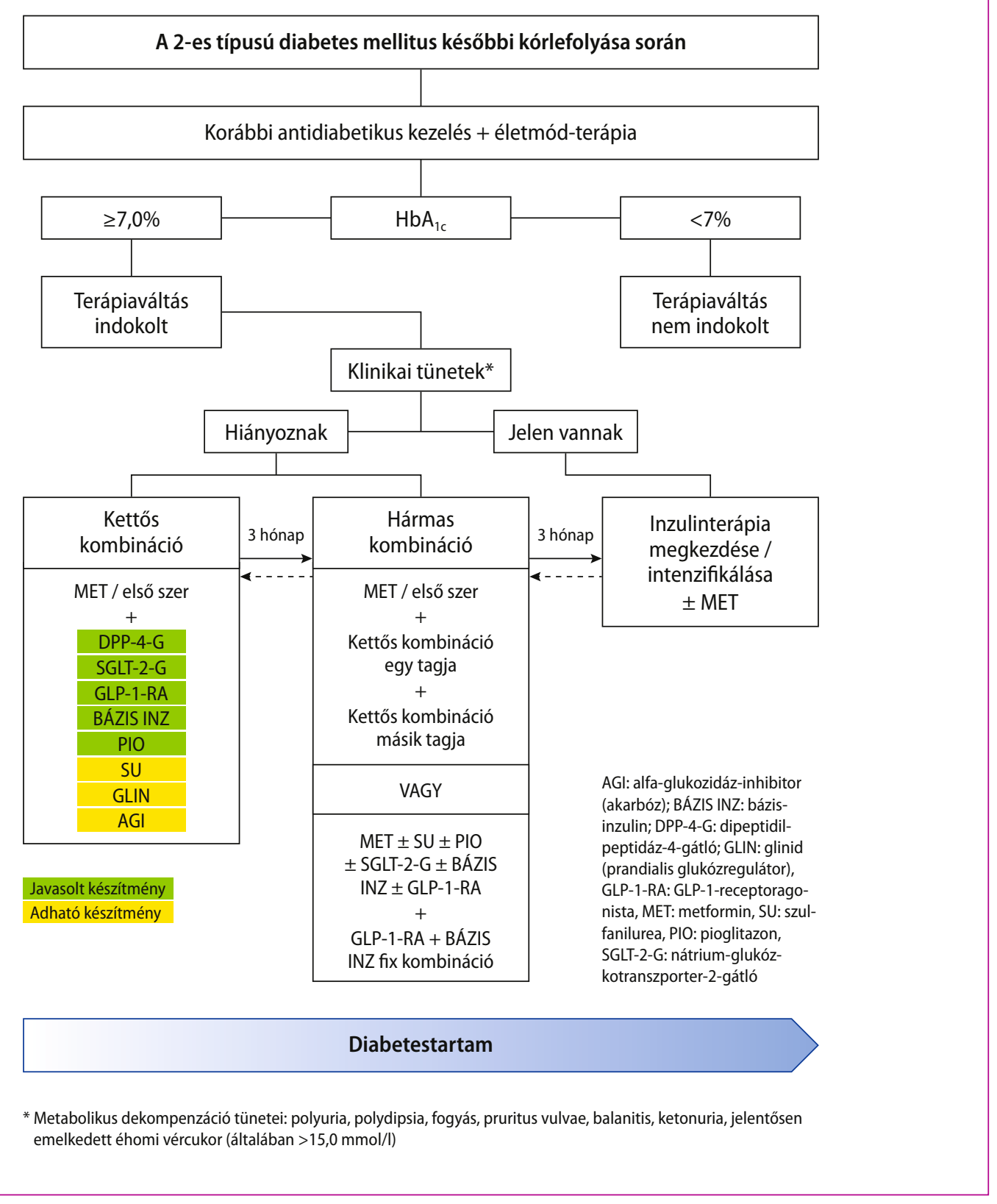

4. ábra. Szakmailag megalapozott terápiás lépések a 2-es típusú diabetes mellitus évekre elnyúló kórlefolyása során

A kezelési célérték általában $\mathrm{Hb}_{1 c}<7,0 \%$ (kezelési céltartomány 6,0-8,0\%). A következő kezelési lépcsőre való áttérést akkor kell megfontolni, ha a beteg az adott kezelés mellett nem érte el az egyénileg megállapított célértéket, általában 3 hónapig tartó kezelés során.

A kezelési rendszerekben visszafelé is lehet haladni, ha azt klinikai körülmények indokolják.

GLP-1-RA és DPP-4-gátló együttadása kerülendő!

SU és GLIN együttadása kerülendő! 
Nincs egységes nemzetközi gyakorlat a tekintetben, hogy a frissen felfedezett 2-es típusú cukorbetegségben életmódkezelés legyen-e az első lépés, avagy kerüljön sor egyidejüleg vércukorcsökkentő gyógyszer alkalmazására is. ${ }^{4,28}$ A korábbi hazai gyakorlat megengedhetőnek tartotta életmódkezelés önmagában történő alkalmazását első kezelési lépésként, ha a glykaemiás kontroll csak kis mértékben tér el a kívánttól $\left(\mathrm{HbA}_{1 \mathrm{c}}<8,0-8,5 \%\right)$, a diabetes valószínűsíthetően rövid ideje áll fenn (a rendelkezésre álló adatok szerint manifesztálódásától <1 év telt el), s nincs ismert diabeteses szövődmény. Ezekben az esetekben ugyanis az életmódkezelés elsajátítása kínálta edukációs előny nagyobb lehet, mint a szoros anyagcserekontroll időben elcsúszó kialakulása jelentette veszély. Ugyanakkor, ha az anyagcsere jelentősebb mértékben károsodott $\left(\mathrm{HbA}_{1 \mathrm{c}}>9,0 \%\right)$, de kife-

\section{6. táblázat. A metformin rendelésének biztonsági elöírásai}

Kerülendő metformin adása, ha

- az eGFR $<45 \mathrm{ml} / \mathrm{min} / 1,73 \mathrm{~m}^{2 *, * *}$

- májelégtelenség

- a napi szénhidrátbevitel - pl. fogyókúra céljából - <100 gramm

- hypoxia áll fenn, illetve annak ismételt előfordulásával kell számolni

Egyes források idesorolják a rendszeres alkoholizálást és az ismétlődő hasnyálmirigy-gyulladások előfordulását is.

* Az eGFR a becsült (estimated) glomerularis filtrációs rátát jelöli (CockroftGault-képlettel számolva)

** GFR 45-60 ml/min tartományban a metformin csak csökkentett dózisban (maximum napi $1500 \mathrm{mg}$ ) adható

7. táblázat. A 2-es típusú diabetes vércukorcsökkentő kezelésének választásakor mérlegelendő körülmények

\begin{tabular}{|c|c|}
\hline $\begin{array}{l}\text { Beteg meghatározta } \\
\text { szempontok }\end{array}$ & $\begin{array}{c}\text { Antidiabetikumtól függő } \\
\text { szempontok }\end{array}$ \\
\hline $\begin{array}{l}\text { - életkor, várható élettartam } \\
\text { - diabetes-tartam } \\
\text { - társuló (kardiovaszkuláris, } \\
\text { renalis, hepatikus) } \\
\text { betegségek } \\
\text { - túlsúly/elhízás } \\
\text { - hyperglykaemia mértéke } \\
\text { - hypoglykaemia kockázata } \\
\text { - szociális környezet } \\
\text { - a beteg preferenciája, anyagi } \\
\text { teherbíró képessége }\end{array}$ & $\begin{array}{l}\text { - glykaemiás hatékonyság és } \\
\text { annak tartóssága } \\
\text { - hypoglykaemizáló } \\
\text { tulajdonság } \\
\text { - testsúlyra gyakorolt hatás } \\
\text { - kardiovaszkuláris } \\
\text { biztonságosság/előny } \\
\text { - potenciális mellékhatások } \\
\text { - a kezelés költsége }\end{array}$ \\
\hline
\end{tabular}

jezett diabeteses tünetek nem álltak fenn, primer kombinált kezelés indítását javasolta az irányelv. ${ }^{28}$

Elsőként a Kanadai Diabetes Társaság (Canadian Diabetes Association: CDA) emelte követendő gyakorlattá az anyagcsere-állapothoz igazodó intenzitású vércukorcsökkentő kezelést, ${ }^{31}$ ezt követte az Amerikai Endokrinológiai Társaságok (American Association of Clinical Endocrinologists [AACE] és American College of Endocrinology [ACE]) hasonló közös állásfoglalása. ${ }^{30}$ E szemlélet klinikai előnyeit felismerve állította megújított ajánlása középpontjába a Magyar Diabetes Társaság (MDT) is ezt az elvet.

Anyagcsere-állapothoz igazodó intenzitású vércukorcsökkentő kezelés alkalmazandó a 2-es típusú diabetes későbbi kórlefolyása során is, a terápiaváltásnál a kezelési célérték $\left(\mathrm{HbA}_{1 \mathrm{c}}<7,0 \%\right.$, illetve egyéni terápiás cél $6,0-8,0 \%$ között), illetve $\geq 7,0 \%$ érték esetén diabetesre jellemző klinikai tünetek fennállása vagy hiánya lehet a mérlegelési tényező (4. ábra).

\section{Ajánlás 20}

A 2-es típusú diabetes elsőként választandó vércukorcsökkentő gyógyszereként metformint kell alkalmazni, ellenjavallat/intolerancia hiányában. („A”)

Metformin első antidiabetikumként történő választását a 2-es típusú diabetes alapvető patogenetikai tényezőit befolyásoló természete (csökkenti az inzulinrezisztenciát, a GLP-1-elválasztás serkentésével, közvetve javítja az inzulinelválasztást), keringési kockázatot csökkentő pleiotrop hatásspektruma, valamint az alkalmazásával kapcsolatos előírások (6. táblázat) betartása mellett biztonságos alkalmazása, kedvező ára indokolja.,28,110,111 Az első gyógyszeres kezelés bevezetése történhet az életmód-terápia megkezdésével egy időben vagy néhány hónappal később is.

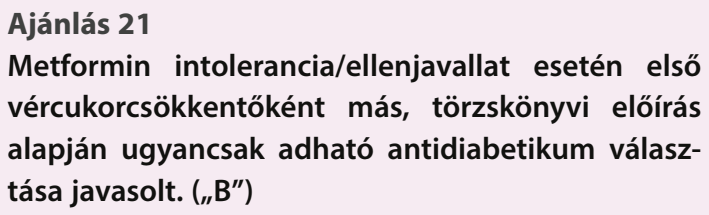

A 2-es típusú diabetes vércukorcsökkentő kezelésének tervezésekor, az adott esetben legmegfelelőbb gyógyszer megválasztásához beteg, illetve 
készítmény meghatározta szempontokat kell figyelembe venni (7. táblázat). ${ }^{4,5,28,31,112}$

Együttes mérlegelésük alapján, a hatályos törzskönyvi elöírások figyelembevételével választható ki a monoterápiásan is adható készítmény. A 3. ábrán zölddel jelölve szerepelnek a preferálandó, sárgával a megengedhetően választandó antidiabetikumok. Az egyes készítmények választásánál a javallatok és ellenjavallatok, az érintett személy diabetesének és egészségi állapotának, továbbá kéréseinek, egyéni igényeinek gondos mérlegelése kívánatos. Figyelembe kell venni azt is, hogy a mindenkori finanszírozási előírások eltérhetnek a szakmai ajánlástól, ezért a választásnál a finanszírozási szempontokat is figyelembe kell venni.

\section{Idős vagy nagyon idős cukorbetegek kezelésekor mérlegelendő szempontok}

Indokolt röviden összefoglalni azokat a szempontokat, amelyek mérlegelése különösen fontos idős vagy nagyon idős cukorbetegek kezelése során, miután ebben az életkori tartományban meglehetősen sok beteg szerepel.

A kórismézéskor fontos tudni, hogy a diagnosztikai kritériumok (2. táblázat) nem életkorfüggőek, azok tehát magas életkorban is érvényesek.

A kezelési célérték esetében a céltartomány felső része $\left(\mathrm{HbA}_{1 \mathrm{c}} 8,0 \%\right)$, olykor még e fölötti érték is nyugodtan elfogadható, hiszen egy esetleges rosszabb anyagcserekontrollnak késői szövődményeket előidéző hatására már nem kell számítani, a túl alacsony $\mathrm{Hb}_{1 \mathrm{c}}$-célérték viszont magában foglalja a hypoglykaemia fokozott kockázatát.

$\mathrm{Az}$ életmód-terápia ebben az életkori tartományban is fontos, természetesen a fizikai aktivitásnak igazodni kell a beteg általános állapotához. Magas életkorban a fizikai aktivitás leginkább sétálást, kertészkedést jelent a betegek többségében.

$\mathrm{Az}$ antidiabetikus terápia megválasztásakor a legfontosabb mérlegelési körülmény az, hogy olyan készítményeket kell választani, amelyek nem növelik a hypoglykaemia kockázatát. Időskorban a hypoglykaemia (olykor a fel nem ismert éjszakai hypoglykaemia) kognitív funkciózavart, szerencsétlen esetben maradandó cerebrális károsodást okozhat, de olykor fatális is lehet, miután a hypoglykaemia növelheti a kardiovaszkuláris események kockázatát is. Fontos mérlegelési körülmény a vesefunkció eset- leges károsodása, miután e betegek körében nem ritka a GFR csökkenése. A választott készítmény dózisának minden esetben illeszkednie kell a GFRértékhez. Idős betegek körében az inzulinterápia lehetőség szerint kerülendő, ha az mégis indokolt, akkor ebben a korban általában a BOT rendszer vagy a kétszeri adagolású előkevert (premix) inzulin elégséges szokott lenni, s az inzulinterápia intenzifikálására nincs szükség. Természetesen idős betegek körében mindig tekintettel kell lenni a szociális körülményekre, az anyagi teherbíró képességre is.

\section{Ajánlás 22}

Jelentősebb anyagcsere-károsodás fennállásakor $\left(\mathrm{HbA}_{1 \mathrm{c}}>\mathbf{8 , 0}-\mathbf{9}, 0 \%\right)$ nem-inzulintermészetű antidiabetikum-kombináció, >9,0\%-os $\mathrm{HbA}_{1 \mathrm{c}}$-érték esetén orális és/vagy parenterális vércukorcsökkentőket tartalmazó hármas kombináció és/vagy inzulin, kifejezett katabolikus tünetek egyidejü észlelésekor inzulinkezelés ( \pm metformin) választása célszerü. („C')

A 2-es típusú diabetesben az ellenjavallatok figyelembevételével minden vércukorcsökken-

\section{8. táblázat. Az antidiabetikumok hatástani felosztása}

$$
\begin{aligned}
& \text { Nem-inzulintermészetű vércukorcsökkentők } \\
& \text { 1. Inzulinfüggő hatásmechanizmusú szerek } \\
& \text { a) Orális antidiabetikumok } \\
& \text { • inzulinhatást erősítő szerek } \\
& \text { - metformin* } \\
& \text { - pioglitazon** } \\
& \text { - alfa-glukozidáz-gátlók*** } \\
& \text { - inzulinelválasztást serkentő készítménycsoportok } \\
& \text { - hagyományos szekretagóg szerek } \\
& \text { - szulfanilureák (gliclazid, glimepirid, gliquidon, } \\
& \text { glipizid, glibenclamid) } \\
& \text { - glinidek (nateglinid, repaglinid) } \\
& \text { - inkretin mechanizmusú szerek } \\
& \text { - DPP-4-gátlók (sita-, vilda-, lina-, saxa-, alogliptin) } \\
& \text { b) Parenterális antidiabetikumok } \\
& \text { - GLP-1-mimetikumok } \\
& \text { - rövid (prandialis) hatású készítmények (exenatid napi } \\
& 2 x \text {, lixisenatid) } \\
& \text { - hosszú hatású készítmények (exenatid heti 1×, lira-, } \\
& \text { dula-, albiglutid) } \\
& \text { 2. Inzulintól független hatásmechanizmusú szerek: } \\
& \text { - SGLT-2-gátlók (dapa-, empa-, canagliflozin) } \\
& \text { Inzulinok }
\end{aligned}
$$


tő készítménycsoport (8. táblázat) alkalmazása megengedett. ${ }^{4,5,28,31}$ Egymással való kombinációs lehetőségeiket a törzskönyvi előírások szabályozzák. A 3. és 4. ábrán zölddel jelöltek az általában előnyben részesítendő, sárgával a megengedett antidiabetikum-kombinációk. ${ }^{4,28,30,31}$

\section{Ajánlás 23}

A 2-es típusú diabetes már megkezdett antidiabetikus kezelésének folytatásakor vagy váltásakor a $\mathrm{HbA}_{1 \mathrm{c}}$-vel jellemzett anyagcsere-állapotot, valamint a katabolikus tünetek fennálltát vagy hiányát indokolt figyelembe venni. („E")

Már megkezdett vércukorcsökkentő kezelés folytatásakor az anyagcsere kívánttól elmaradó állapota esetén a 4. ábrán feltüntetettek szerint kettős vagy hármas antidiabetikum-kombináció adható. Előnyben részesítendők a testsúlyt kedvezően befolyásoló (testsúlycsökkentő vagy testsúlysemleges), alacsony hypoglykaemia-kockázattal járó, a keringési kockázatot csökkentő készítménycsoportok. ${ }^{4,5,28,31}$ A választáskor figyelembe kell venni a szénhidrát-anyagcsere aktuális jellemzőit is (éhomi, étkezés utáni vércukorszint).

\section{Ajánlás 24 \\ Az antidiabetikus kezelés megválasztásának beteg- központúnak kell lennie. („E”)}

A mérlegelési szempontok között a hatástani előnyöket, lehetséges mellékhatásokat, a kezelendő személy testsúlyát, keringési kockázatát, a kezelés várható eredményességét és költségkihatásait is indokolt figyelembe venni. Az egyes antidiabetikum-csoportok főbb jellemzőit a 9. táblázat, a beteg klinikai jellemzői alapján történő választási lehetôségeket a 10. táblázat foglalja össze.

$\mathrm{Az}$ inzulinszekréciót serkentő szerek közül glukózdependens vércukorcsökkentő, az alfa-sejtek működésére is ható, testsúlyt előnyösen befolyásoló (testsúlysemleges [DPP-4 gátlók], illetve testsúlycsökkentő [GLP-1-mimetikumok]) természetük, kedvező pleiotrop tulajdonságaik folytán előnyt élveznek az inkretinhatású csoportok. ${ }^{113}$ Inzulintól független hatásmechanizmusú, az inzulin-

9. táblázat. A 2-es típusú diabetes kezelésében használatos antidiabetikumok adásakor mérlegelendő körülmények

\begin{tabular}{|c|c|c|c|c|c|c|c|c|c|}
\hline & $\begin{array}{l}\text { Met- } \\
\text { formin }\end{array}$ & $\begin{array}{l}\text { DPP-4- } \\
\text { gátló }\end{array}$ & $\begin{array}{l}\text { SGLT-2- } \\
\text { gátló }\end{array}$ & $\begin{array}{l}\text { GLP-1- } \\
\text { receptor- } \\
\text { agonista }\end{array}$ & $\begin{array}{c}\text { Pio- } \\
\text { glitazon }\end{array}$ & $\begin{array}{c}\text { Szulfanil- } \\
\text { urea }\end{array}$ & Glinidek & $\begin{array}{l}\text { Alfa-glu- } \\
\text { kozidáz- } \\
\text { inhibitor }\end{array}$ & Inzulin \\
\hline $\begin{array}{c}\text { Antihyperglykaemiás } \\
\text { hatás }\end{array}$ & $\uparrow \uparrow-\uparrow \uparrow \uparrow$ & $\uparrow \uparrow$ & $\uparrow \uparrow-\uparrow \uparrow \uparrow$ & $\uparrow \uparrow \uparrow$ & $\uparrow \uparrow$ & $\uparrow \uparrow$ & $\uparrow \uparrow$ & $\uparrow$ & $\uparrow \uparrow \uparrow$ \\
\hline $\begin{array}{l}\text { Hypoglykaemia- } \\
\text { kockázat }\end{array}$ & $\begin{array}{c}\text { nem } \\
\text { változik }\end{array}$ & $\begin{array}{c}\text { nem } \\
\text { változik }\end{array}$ & $\begin{array}{c}\text { nem } \\
\text { változik }\end{array}$ & $\begin{array}{c}\text { nem } \\
\text { változik }\end{array}$ & $\begin{array}{c}\text { nem } \\
\text { változik }\end{array}$ & nő & nő & $\begin{array}{c}\text { nem } \\
\text { változik }\end{array}$ & nő \\
\hline Testsúly & $\begin{array}{l}\text { csökken } \\
\text { (mér- } \\
\text { sékelt) }\end{array}$ & $\begin{array}{l}\text { nem } \\
\text { változik }\end{array}$ & csökken & csökken & nő & nő & nő & $\begin{array}{c}\text { nem } \\
\text { változik }\end{array}$ & nő \\
\hline $\begin{array}{l}\text { Gastrointestinalis } \\
\text { mellékhatás }\end{array}$ & $\uparrow$ & $\leftrightarrow$ & $\leftrightarrow$ & $\uparrow$ & $\leftrightarrow$ & $\leftrightarrow$ & $\leftrightarrow$ & $\uparrow$ & $\leftrightarrow$ \\
\hline $\begin{array}{l}\text { Genitális fertőzés } \\
\text { előfordulása }\end{array}$ & $\leftrightarrow$ & $\leftrightarrow$ & $\uparrow$ & $\leftrightarrow$ & $\leftrightarrow$ & $\leftrightarrow$ & $\leftrightarrow$ & $\leftrightarrow$ & $\leftrightarrow$ \\
\hline $\begin{array}{l}\text { Kardiovaszkuláris } \\
\text { biztonságosság }\end{array}$ & elönyös & $\leftrightarrow$ & elönyös* & előnyös** & elönyös & $\leftrightarrow$ & $\leftrightarrow$ & $\leftrightarrow$ & $\leftrightarrow$ \\
\hline $\begin{array}{l}\text { Szívelégtelenség } \\
\text { kockázata }\end{array}$ & $\begin{array}{l}\text { nem } \\
\text { változik }\end{array}$ & nő*** & csökken* & $\begin{array}{c}\text { nem } \\
\text { változik }\end{array}$ & nő & $\leftrightarrow$ & $\leftrightarrow$ & $\leftrightarrow$ & $\leftrightarrow$ \\
\hline Csonttörés kockázata & $\leftrightarrow$ & $\leftrightarrow$ & $\leftrightarrow$ & $\leftrightarrow$ & $\uparrow$ & $\leftrightarrow$ & $\leftrightarrow$ & $\leftrightarrow$ & $\leftrightarrow$ \\
\hline $\begin{array}{l}\text { Beteget terhelő } \\
\text { kezelési költség }\end{array}$ & átlagos & jelentős & jelentős & kifejezett & jelentős & átlagos & jelentős & jelentős & átlagos \\
\hline
\end{tabular}

Hatás/mellékhatás: $\uparrow$ mérsékelt, $\uparrow \uparrow$ közepes erősségű, $\uparrow \uparrow \uparrow$ kifejezett, $\leftrightarrow$ semleges

* empagliflozin esetében igazolt

** liraglutid esetében igazolt

*** saxagliptin esetén figyelték meg 
10. táblázat. Preferálandó antidiabetikus terápia 2-es típusú diabetesben

\begin{tabular}{|c|c|}
\hline $\begin{array}{l}\text { Testsúlyfelesleg/ } \\
\text { elhízás esetén }\end{array}$ & $\begin{array}{l}\cdot \text { - MET } \\
\text { - MET + GLP-1-RA } \\
\text { - MET + SGLT-2-G } \\
\text { - Levemir (ha inzulinterápia szükséges) }\end{array}$ \\
\hline $\begin{array}{l}\text { Fokozott } \\
\text { hypoglykaemia- } \\
\text { kockázat esetén }\end{array}$ & $\begin{array}{l}\cdot \text { MET } \\
\cdot \text { MET + DPP-4-G } \\
\cdot \text { MET + SGLT-2-G } \\
\cdot \text { MET + PIO } \\
\cdot \text { MET + GLP-1-RA } \\
\cdot \text { Inzulinanalógok (ha inzulinterápia } \\
\text { szükséges) }\end{array}$ \\
\hline $\begin{array}{l}\text { Kardiovaszkuláris } \\
\text { esemény után }\end{array}$ & $\begin{array}{l}\cdot \text { MET } \\
\cdot M E T+S G L T-2-G^{*} \\
\cdot M E T+G L P-1-R A^{* *} \\
\end{array}$ \\
\hline $\begin{array}{l}\text { Hypertonia esetén } \\
\text { (de: a hypertoniát } \\
\text { antihypertensiv } \\
\text { szerrel kell kezelni) }\end{array}$ & $\begin{array}{l}\cdot \mathrm{MET} \\
\cdot \mathrm{MET}+\mathrm{SGLT}-2-\mathrm{G} \\
\cdot \mathrm{MET}+\mathrm{GLP}-1-\mathrm{RA}\end{array}$ \\
\hline $\begin{array}{l}\text { Vesefunkció- } \\
\text { károsodás esetén }\end{array}$ & $\begin{array}{l}\text { Az antidiabetikumok alkalmazhatósága } \\
\text { függ a vesefunkciótól (az eGFR-értéktől). } \\
\text { Az alkalmazási előírásokban rögzített } \\
\text { lehetőségeket az 5. ábra szemlélteti. }\end{array}$ \\
\hline $\begin{array}{l}\text { Financiális gondok } \\
\text { esetén }\end{array}$ & $\begin{array}{l}\cdot \mathrm{MET} \\
\cdot \mathrm{MET}+\mathrm{SU}\end{array}$ \\
\hline
\end{tabular}

* empagliflozin

** liraglutid

MET: metformin, SU: szulfanilurea, PIO: pioglitazon, DPP-4-G: DPP-4-gátló SGLT-2-G: SGLT-2-gátló, GLP-1-RA: GLP-1-receptoragonista

hatást és az inzulinelválasztást egyaránt javító, a keringési kockázati tényezőket előnyösen befolyásoló tulajdonságuk folytán preferálandó a gliflozinok kombinációs alkalmazása is. ${ }^{114} \mathrm{~A}$ kardiovaszkuláris kockázat alakulása fontos körülmény. ${ }^{115} \mathrm{~A}$ DPP-4-gátlók között a saxagliptin, az alogliptin és a sitagliptin kardiovaszkuláris biztonságossága dokumentált. ${ }^{115}$ Az EMPA-REG OUTCOME vizsgálat az empagliflozin keringési eseményeket csökkentő hatását, ${ }^{116}$ a LEADER vizsgálat a liraglutid kardiovaszkuláris előnyét dokumentálta. ${ }^{117} \mathrm{Az}$ ELIXA a lixisenatid kardiovaszkuláris biztonságosságát igazolta. ${ }^{115}$ A hagyományos inzulinszekretagóg csoportok (szulfanilureák, glinidek) választása vércukorszinttől független inzulinelválasztást fokozó és ezáltal fokozott hypoglykaemia-kockázattal járó, súlygyarapodást elősegítő természetük folytán kevéssé tanácsolható. ${ }^{4,28}$ A szulfanilurea-csoporton belül egyedi előnyei révén gliclazid választása célszerü. ${ }^{118}$ Kedvezőtlen keringési hatásoktól mentes a funkcionálisan pancreas-szelektív
11. táblázat. A két inkretinhatású gyógyszercsoport föbb, klinikai vonatkozású különbségei

\begin{tabular}{|c|c|c|}
\hline & DPP-4-gátlók & $\begin{array}{l}\text { GLP-1- } \\
\text { receptor- } \\
\text { agonisták }\end{array}$ \\
\hline Alkalmazás módja & per os & parenterális \\
\hline $\begin{array}{l}\text { Átlagos } \mathrm{HbA}_{1 \mathrm{c}} \text {-csökkenés } \\
\text { monoterápiás alkalmazásban }\end{array}$ & $0,6-1,4 \% *$ & $0,6-1,8 \%$ * \\
\hline Adagok száma & napi 1-2 & napi 2 - heti 1 \\
\hline Érvényesülő inkretinhatás & GLP-1, GIP & GLP-1 \\
\hline GLP-1-hatás & élettani & farmakológiai \\
\hline Inzulinelválasztás & $\uparrow$ & $\uparrow \uparrow$ \\
\hline Glukagonelválasztás & $\downarrow$ & $\downarrow$ \\
\hline Étvágycsökkenés & - & + \\
\hline Gyomorürülés lassulása & - & eltérő** \\
\hline Testsúly & $\begin{array}{l}\text { nem változik/ } \\
\text { csökken }\end{array}$ & csökken \\
\hline Mellékhatás & $\begin{array}{l}\text { megfázásszerü } \\
\text { tünetek }\end{array}$ & $\begin{array}{l}\text { émelygés, } \\
\text { hányinger*** }\end{array}$ \\
\hline Bevezetéskor dózistitrálás & - & $t^{* * * *}$ \\
\hline \multicolumn{3}{|c|}{$\begin{array}{l}\text { *Az adatok erősen szórnak } \\
{ }^{* *} \text { A rövid hatásúak esetében igazolható, a hosszú hatású változatok } \\
\text { esetében nem igazolható } \\
\text { *** Elsősorban a kezelés kezdetén } \\
\text { *** Napi } 1-2 \text { alkalommal adandó változatok esetében }\end{array}$} \\
\hline
\end{tabular}

természetű glimepirid is. ${ }^{118}$ Gliquidon választása nem-renalis eliminációja révén beszűkült veseműködés esetén képezheti mérlegelés tárgyát. ${ }^{118}$

A két inkretinhatású csoport (DPP-4 gátlók, illetve GLP-1-receptoragonisták) hatástani sajátságaiban mutatkozó főbb klinikai különbségeket a 11. táblázat szemlélteti. ${ }^{113}$ A GLP-1-receptoragonisták rövid és hosszú hatású változatainak hatástani eltéréseit a 12. táblázatban foglaljuk össze. Mivel a klinikai gyakorlat szempontjából ez utóbbiak között a gyomorürülést befolyásoló és ezzel összefüggésben, az étkezéseket követő vércukorszintet jobban/kevésbé mérséklő természetük a legjelentősebb, az irodalom újabb keletű elnevezéssel prandialis (rövid hatású) és nem-prandialis (hosszú hatású) alcsoportokat különböztet meg. ${ }^{119,120}$ A prandialis és nem-prandialis készítmények összevetését illetően ez idő szerint kevés az evidencia. Egy kis esetszámú, rövid vizsgálatban a prandialis hatású szer valamivel erőteljesebben csökkentette az étkezés utáni vércukorszintet a beadása utáni időben, a nap egészében azonban a hosszú hatású szer hatékonyabb vércukorcsökkenést eredményezett. 
12. táblázat. A rövid (prandialis) és hosszú hatású (nem-prandialis) GLP-1-receptoragonisták jellemzői

\begin{tabular}{|c|c|c|}
\hline & Rövid hatású készítmények & Hosszú hatású változatok \\
\hline Hatóanyagok & exenatid napi $2 \times$, lixisenatid & liraglutid, exenatid heti $1 \times$, dulaglutid, albiglutid* \\
\hline Félélet-idő & $2,0-4,3$ óra & 12 óra - néhány nap \\
\hline Éhomi vércukorszint & $\downarrow$ & $\downarrow \downarrow$ \\
\hline Étkezés utáni vércukorszint & $\downarrow$ & $\downarrow$ \\
\hline Szérum éhomi inzulin & $\uparrow$ & $\uparrow \uparrow$ \\
\hline Szérum étkezés utáni inzulin & $\downarrow$ & $\uparrow$ \\
\hline Szérum glukagon & $\downarrow$ & $\downarrow$ \\
\hline Gyomorürülés & lassul & nincs hatás \\
\hline Vérnyomás & $\downarrow$ & $\downarrow$ \\
\hline Szívfrekvencia & nem változik/^ (0-2 ütés/min) & $\uparrow(2-5$ ütés/min) \\
\hline Testsúlycsökkenés & $1-4 \mathrm{~kg}$ & $2-5 \mathrm{~kg}$ \\
\hline Adagok száma & $\begin{array}{l}\text { napi } 1 \times \text { : lixisenatid } \\
\text { napi } 2 \times \text { : exenatid }\end{array}$ & $\begin{array}{c}\text { napi } 1 \times \text { : liraglutid } \\
\text { heti } 1 \times \text { : exenatid, dulaglutid, albiglutid* }\end{array}$ \\
\hline
\end{tabular}

* Európában regisztrált, de ez idő szerint hazánkban nincs forgalomban

Forgalomba került az első, bázisinzulin-analóggal (degludek) fix összetételű GLP-1-receptoragonista (liraglutid) készítmény is. Bár elvben metformin után, második-harmadik szerként is adható (ez a kombináció valójában három-négy különböző vércukorcsökkentő adását jelenti), alkalmazása elsősorban GLP-1-receptoragonistát tartalmazó antidiabetikum-kombináció bázisinzulinnal történő kiegészítésekor, illetve BOT-kezelés GLP-1receptoragonistával történő kombinálásakor merül fel. ${ }^{113,121,122,123}$

Jelentősebb anyagcsere-eltérés esetén a kettős vagy hármas kombinációs első kezelés, illetve az inzulinterápiával történő kezelésindítás az életmód-terápiával egy időben kezdődik. ${ }^{30,31}$ A következő kezelési lépcsőre való áttérést akkor kell megfontolni, ha a beteg az adott kezelés mellett nem érte el az egyénileg megállapított célértéket, általában 3 hónapig tartó kezelés során. ${ }^{4,5,28,30,31}$

\section{Ajánlás 25 \\ Vércukorcsökkentő kombinációs terápia megvá- lasztásakor az összetevők egyedi sajátosságainak figyelembevétele kívánatos. (,C C )}

Fontos annak szem előtt tartása, hogy két vagy három vércukorcsökkentő készítmény együttes adása egymás hatását erősítheti (pl. metformin és GLP1-receptoragonista, metformin és DPP-4-gátló), de gyengítheti is (pl. pioglitazon és DPP-4-gátló kombinációjának testsúlyra gyakorolt hatása).
Ugyanígy, kombinálásukkor adásuk külön-külön ellenjavallatait is mérlegelni szükséges. A készítményválasztást több mérlegelési szempont együttes értékelése (a vércukorszint-emelkedés típusa [étkezés utáni és/vagy éhomi], a választandó készítmény inzulinhatást vagy inzulinelválasztást erősítő természete, experimentálisan, illetve humán közvetett adatok alapján igazolt béta-sejt-kímélő hatás fennállása vagy hiánya, az érintett személy tápláltsági állapota, életkora, társbetegségei, a választandó készítmény keringési kockázatot, atherogenesist befolyásoló tulajdonsága stb.) segíti. ${ }^{4,28,30,31}$ A 2-es típusú diabetest gyakrabban kísérő állapotok, társbetegségek esetén tanácsolható gyógyszer/gyógyszerkombináció-választást a 10 . táblázat, a veseműködés választást befolyásoló szerepét az 5. ábra foglalja össze.

$\mathrm{Az}$ előzőekben részben már érintett vércukorcsökkentő hatástani csoportok főbb jellegzetességei az alábbiak szerint foglalhatók össze.

\section{Metformin}

Az adásával kapcsolatos ellenjavallatokat/biztonsági előírásokat a 6. táblázat tartalmazza. A szer legsúlyosabb potenciális mellékhatása a tejsavacidózis, fellépése azonban ritka, 0,01-0,084/1000 betegév. Egyéb mellékhatásai között gastrointestinalis diszkomfort-panaszok, lágyabb széklet, hasmenés, igen ritkán $\mathrm{B}_{12}$-vitaminhiány - és annak klinikai következményeként hátsóköteg-károso- 


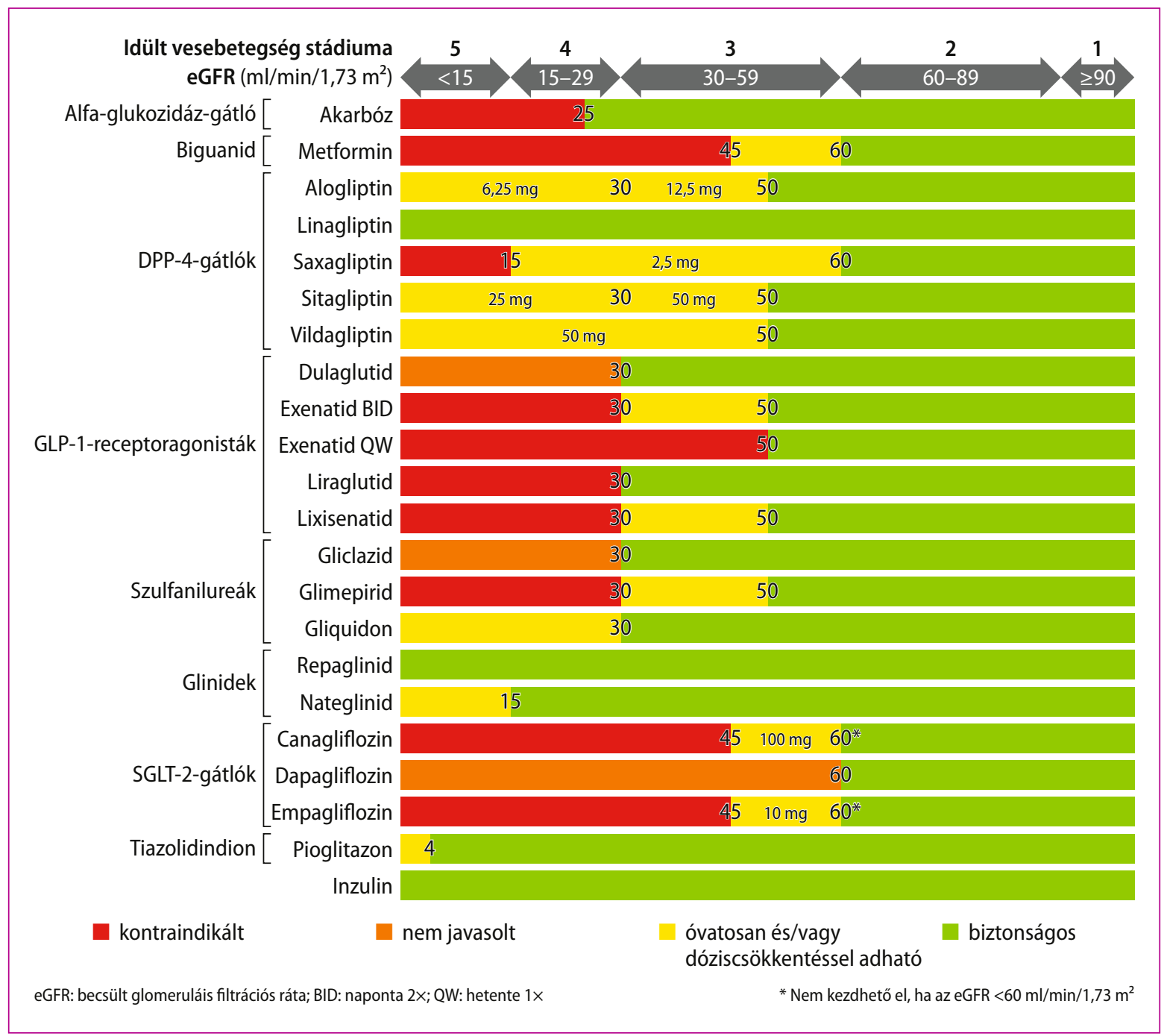

5. ábra. Antidiabetikumok alkalmazási lehetösége idült vesebetegség, csökkent vesefunkció esetén (Forrás: Canadian Diabetes Association Clinical Practice Guidelines Expert Committee: Can J Diabetes 2015; 39: 250-252.)

dás, funicularis myelosisra emlékeztető kép - fordulhatnak elő. A hasi panaszok kis kezdőadag (500 mg) alkalmazásával, s fokozatos dózisemeléssel nagyrészt elkerülhetők. Enyhe panaszok esetén kísérlet tehető napi egyszer, lefekvéskor egy adagban beveendő, elhúzódó hatóanyag-felszabadulást biztosító (extended release) készítményváltozattal. Önmagában adva - az ún. antihyperglykaemiás szerek más képviselőivel egyezően - hypoglykaemiát nem okoz. Maximális napi adagja $3000 \mathrm{mg}$, de 2000 mg napi adag felett a dózis-hatás görbe el- lapul. Jódos kontrasztanyaggal történő radiológiai vizsgálat előtt 48 órával a metformin elhagyandó, az újrakezdés a vizsgálat után 24-48 órával történhet. A metformin fenntartása - intolerancia, ellenjavallat hiányában - a 2-es típusú diabetes egész tartama alatt javasolt. Adása előnyeit és az óvatossági előírások betartása mellett történő adagolása biztonságos voltát szem előtt tartva a veseműködés adását korlátozó határértékét lejjebb szállították: $45 \mathrm{ml} / \mathrm{min} / 1,73 \mathrm{~m}^{2}$ eGFR-értékig adható, a 60-45 közötti tartományban azonban napi 
maximálisan 1500 mg-os adagban. ${ }^{110,111}$ E módosítás a hazai törzskönyvekben még csak néhány készítmény esetében jelent meg, több törzskönyvmódosítás azonban folyamatban van.

\section{Tiazolidindionok}

A hatástani csoport Európában jelenleg elérhető egyetlen képviselője a pioglitazon. Míg a metformin döntően a máj glukózkibocsátását csökkenti, a pioglitazon egy magreceptor, a peroxisoma proliferációt aktiváló receptor (PPAR)- $\gamma$ serkentésén keresztül elsősorban a zsír- és izomszövet glukózfelvételét javítja, de kis mértékben mérsékli a hepatikus glukóztermelést is. Adása ellenjavallt a hepatoparenchymás enzimek kétszeresnél nagyobb emelkedésével járó májműködési zavarban, keringési elégtelenség fennállásakor. Vesekárosodás esetén nem szükséges az adag módosítása, a készítmény $>4$ $\mathrm{ml} / \mathrm{min}$ kreatinin clearence esetén alkalmazható. A pioglitazon zsíranyagcsere-hatásai kedvezőek, amit a molekula parciális PPAR- $\alpha$ serkentő természete magyaráz. Feltehetően erre visszavezethetően kedvezőbbnek bizonyult a készítmény kardiovaszkuláris kimenetelre gyakorolt hatása is. A készitmény mellékhatásaként folyadékretenció, a zsírkompartmentek közötti eloszlás előnyös változásával kísért súlygyarapodás, dilutiós anaemia, macula oedema fordulhat elő, s fokozódhat az atípusos helyeken előforduló csonttörési gyakoriság is. A pioglitazon napi adagja $1 \times 15-45 \mathrm{mg}$. ${ }^{124}$

\section{Étkezési vércukor-szabályozók (prandialis glukózregulátorok, glinidek, meglitinidek)}

Az étkezésre bekövetkező inzulinelválasztás korai - első - fázisát serkentik, helyreállítva a 2-es típusú diabetes egyik legkorábbi patogenetikai vonását, e szekréciós fázis kiesését vagy késését, a bázisinzulin-szekréció befolyásolása nélkül. Hatásuk gyorsan kialakul és rövid tartamú - a hypoglykaemia fellépésének kockázata kicsi -, inzulinszekretagóg természetük azonban elmarad a szulfanilureákétól. $\mathrm{Az}$ éhomi vércukorszintet alig befolyásolják. Adásuk az étkezési utáni vércukorszintet ugyancsak hatékonyan csökkentő, de kedvezőbb sajátosságú DPP-4-gátlók forgalomba kerülésével ma már túlhaladottnak tekinthető, a hazai klinikai gyakorlatban egyébként sem terjedtek el.

\section{Szulfanilureák}

Az étkezésre bekövetkező inzulinelválasztás első vagy mindkét fázisát serkentik, de fokozzák a bázisinzulin termelődését is. E tulajdonságuk eredményezi a vércukorszint csökkenését, de potenciális mellékhatásukat, a vércukor esését (hypoglykaemiát) is. A szulfanilurea-receptorhoz való kötődésük alapján megkülönböztetünk pancreas-szelektív (gliclazid) és nem-szelektív - más szövetek, elsősorban a kardiovaszkuláris rendszer szulfanilurea-receptoraihoz (káliumcsatornáihoz) is kötődő - vegyületeket (az összes többi készítmény). Ez utóbbiak a glimepirid kivételével gátolják az ischaemiás prekondicionálás mechanizmusát. Választásuk (gliclazid, glimepirid; beszűkült veseműködés esetén gliquidon) elsősorban financiális gondok felmerülésekor jöhet szóba. ${ }^{118}$ A GUIDE vizsgálat adatai szerint a gliclazid MR a hypoglykaemia-kockázat szempontjából kedvezőbb, mint a glimepirid. ${ }^{125}$ A gliclazid (kivételes esetben a glibenclamid) adásának speciális területét képezheti a MODY típusú diabetes. ${ }^{28,126,127}$

\section{Inkretinhatású szerek}

Csoportjaikkal és azok hatástani sajátosságaival az előzőekben részletesen foglalkoztunk. A vércukorcsökkentés glukózfüggő mechanizmusa révén alkalmazásukkor a hagyományos inzulinszekretagóg szerekéhez képest alacsonyabb a hypoglykaemia fellépésének kockázata. A DPP-4-gátlók mindegyike adható monoterápiában is, más vércukorcsökkentőkkel való kombinálhatóságuk a törzskönyvi előírások függvényében változik. Beszűkült veseműködés mellett történő adagolhatóságukat az 5. ábra szemlélteti. A májműködés károsodása és annak mértéke adásukat eltérő mértékben befolyásolja, e tekintetben a törzskönyvi előírások az irányadók.

A GLP-1-receptoragonisták közül a rövid hatású változatok esetében dózistitrálás szükséges. A naponta kétszer adandó exenatid esetében a kezdő adag $2 \times 5 \mu \mathrm{g}$, ami panaszmentesség esetén két hét elteltével $2 \times 10 \mu \mathrm{g}$-ra emelhető. A lixisenatid kezdőadagja $1 \times 10 \mu \mathrm{g}$, amit ugyancsak két hét elteltével $1 \times 20 \mu$ g-ra kell emelni. A napi egyszer adagolandó liraglutid jóval hosszabb hatástartamú az előzőeknél, ezért a hosszú hatású származékok közé sorolják. Kezdőadagja $1 \times 0,6$ mg, ami két hét elteltével 
1×1,2 mg-ra emelhető. A kívánt hatás elmaradása esetén az adag egy hónap elteltével tovább növelhető $1 \times 1,8$ mg-ra. Más hosszú hatású változatok esetében nincs szükség dózistitrálásra. A heti egyszeri exenatid adagja heti $1 \times 2 \mathrm{mg}$, amelyet mindig a hét azonos napján kell beadni, folyamatos adagolás esetén a terápiás szint az 5-6. hétre alakul ki. A dulaglutid dózisa monoterápiás alkalmazás esetén heti $1 \times 0,75 \mathrm{mg}$, kombinációs alkalmazásakor heti $1 \times 1,5$ mg. Szerkezeti sajátosságai és eltérő szervezetbeli viselkedése révén a terápiás gyógyszerszint a heti egyszeri exenatidhoz viszonyítva valamivel előbb, már a 2-3. héten kialakul. ${ }^{113,119,120}$

\section{Alfa-glukozidáz-gátlók (akarbóz)}

Elsősorban az étkezés utáni vércukorszintet csökkentik, bár tartós alkalmazás mellett mérséklődik az éhomi vércukorérték is. Az akarbóz gastrointestinalis mellékhatásokat, haspuffadást, fokozott bélgázképződést okozhat, ami az adag fokozatos bevezetésével enyhíthető. Szűk sérvkapujú hasi sérvvel rendelkezőkön adása inkább kerülendő. Máj- és vesekárosodás fennállása esetén adása óvatosságot igényel, mert bár csak 3-4\%-a szívódik föl a bélből, a felszivódott rész teljes egészében a májban metabolizálódik, a metabolitok pedig részben a vesén át ürülnek. Néhány esetben megfigyelték - reverzibilis - májenzim-emelkedést okozó hatását. Egy nagy klinikai tanulmányban kedvezőnek bizonyult a kardiovaszkuláris szövődmények visszaszorítása terén, az adatok azonban még megerősítést igényelnek. Átlagos anyagcsere-javító hatása elmarad a metforminétől és a szulfanilureákétól, monoterápiában adva a $\mathrm{HbA}_{1 c}$-értéket $0,5-0,8 \%$-kal csökkentheti. Kezdőadagként este $25 \mathrm{mg}$ javasolt, ami 2-3 naponkénti emeléssel fokozatosan $3 \times 100 \mathrm{mg}$-ig emelhetö. ${ }^{28}$

\section{SGLT-2-gátlók}

A tablettás vércukorcsökkentő szerek új hatástani csoportja, az első regisztrált képviselő, a dapagliflozin után elérhetővé vált az empagliflozin és a canagliflozin is (utóbbit hazánkban nem forgalmazzák). ${ }^{114}$ Vércukorcsökkentő hatásuk független mind az inzulinelválasztástól, mind az inzulinhatástól, a vesék proximális tubulusainak S1 szegmentumában elhelyezkedő nátrium-glukóz kotranszpor- ter (SGLT)-2 reverzibilis gátlása útján fokozzák a glykosuriát. A szer rendszeres adása esetén napi 70 gramm glukóz ürülhet a szervezetből. Monoterápiában átlagos $\mathrm{HbA}_{1 \mathrm{c}}$-csökkentő természetét 0,6-0,8\%-osnak találták. Adható metforminnal, illetve szulfanilurea típusú szerrel kettes, sőt, hármas kombinációban is. Alkalmazási előírása megengedi inzulinnal együtt történő adását is. $\mathrm{Az}$ EMPA-REG OUTCOME vizsgálat az empagliflozin előnyös kardiovaszkuláris hatását támasztotta alá. ${ }^{116}$ A dapagliflozin napi adagja $1 \times 10 \mathrm{mg}$, az empaglifloziné $1 \times 10 \mathrm{mg}$ vagy $1 \times 25 \mathrm{mg}$. Mellékhatásként genitális infekciók gyakoribb voltát írták le.

Kezelés inzulinnal 2-es típusú diabetesben

Minden olyan esetben, amikor életmódkezelés + orális antidiabetikum megfelelő javallattal és adagban történő alkalmazása három hónap elteltével sem biztosítja a kívánt glykaemiás kontrollt ( $\mathrm{HbA}_{1 \mathrm{c}} 6,0-8,0 \%$ között), felmerül az inzulinkezelés bevezetésének szükségessége. Korábban általában két vagy három különböző hatóanyagcsoportba tartozó orális szer hatástalansága esetén került sor az inzulin alkalmazására. Napjainkban egyrészt az új irányelvek, az inzulin korai bevezetésének béta-sejt-kímélő és a rövid időn belül biztosítható jó anyagcsere-állapot szövődmény-megelőző hatását szem előtt tartva ezt már a kezelés korai fázisában, akár a metformin-monoterápia sikertelensége esetén - általában bázisinzulin-kezelés formájában - alternatív választási lehetőségként tekintik. Inzulin tehát 2-es típusú cukorbetegekben már a kezelés második lépcsőjeként alkalmazható. Ugyanakkor egyre több kedvező adat jelent meg a hármas antidiabetikum-kombinációk alkalmazásával kapcsolatban; e betegekben az inzulinkezelés bevezetésére csak e kombinációs kezelés elégtelensége esetén kerül sor.

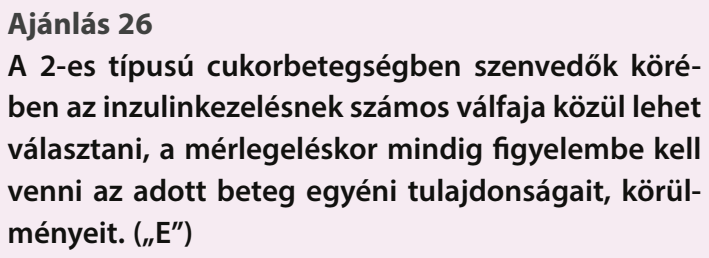

Mérlegelni kell az életkort, a várható életkilátásokat, a diabetes időtartamát, a hypoglykaemia- 
kórtörténetet és kockázatát, a mikro- és makrovaszkuláris diabeteses szövődmények, valamint társbetegségek fennállását, a várható testsúlygyarapodást, továbbá a beteg életvitelét, életkörülményeit és a glykaemiás kontroll megvalósíthatóságát. ${ }^{4} \mathrm{Az}$ idősebb betegek körében az orális antidiabetikum + bázisinzulin kombinációja (BOT-terápia: basal insulin supplemented oral treatment) népszerű, a stabil életvitelű betegek körében helye lehet a konvencionális inzulinterápiának, ill. a szemi-intenzív és prandialis premix rezsimeknek is. Nem szabad azonban megfeledkezni arról, hogy az inzulinterápia intenzifikálására a 2-es típusú diabetes hosszú kórlefolyása során az inzulinnal kezeltek jelentősebb hányadában sort kell keríteni. A bázisinzulinnal folytatott kezelés intenzifikálása sokáig csak a prandialis inzulinnal történő kombinációt, majd teljes bázis-bolus kezelési rendszer felépítését jelentette. Napjainkban azonban az új készítmények a klasszikus, inzulinnal történő intenzifikálásnak alternatív lehetőségeit is kínálják.

\section{Orális antidiabetikum + bázisinzulin kombinációja (BOT-terápia)}

A bázisinzulin-hatás biztosítására korábban csak intermedier hatástartamú, NPH-típusú humán inzulinkészítmények álltak rendelkezésre, amelyeket a kívánt éhomi vércukorszint elérése érdekében lefekvéskor (a magyar nyelvben is meghonosodott angol kifejezéssel „bedtime”) adagoltunk. A hoszszú hatású inzulinanalógok (glargin, detemir, majd degludek) forgalomba kerülése lehetővé tette a beadás más időpontra helyezését. Alkalmazásuk emellett nemcsak az éhomi, hanem az étkezések előtti (preprandialis) vércukorszintek kedvezőbb alakulását is elősegítheti. ${ }^{128,129}$

Ha a lefekvés előtt NPH-típusú inzulint alkalmazunk, akkor ennek kezdő adagja általában 8-12 NE, amely a szükséglethez igazodóan fokozatosan emelhető. A 40 NE meghaladása, a hajnali hypoglykaemia-kockázat fokozódása miatt nem célszerü. Ha glargin vagy bioszimiler glargin adagolását választjuk, ennek beadása a készítmény közel 24 órás hatásából adódóan bármely napszakban lehetséges, de fontos, hogy mindig közel azonos időpontban történjen. Orális antidiabetikus kezeléssel kombinált alkalmazása ese- tén kezdő adagja általában $10 \mathrm{NE}$, ami a reggeli vércukorértékek függvényében fokozatosan emelhető. Bevált egyszerű titrálási rendszer szerint amennyiben három egymást követő nap éhomi vércukorértékeinek átlaga $>6,0 \mathrm{mmol} / \mathrm{l}$ és éjszaka nem fordult elő megélt vércukoresés vagy $<4 \mathrm{mmol} / \mathrm{l}$ alatti mért vércukorszint, az adag 2 E-gel növelhető. Ez a séma folytatandó a fenti célérték (éhomi vércukorszint $<6,0 \mathrm{mmol} / \mathrm{l}$ ) eléréséig, de lehetőség szerint a dózis ne haladja meg a $0,5 \mathrm{E} / \mathrm{kg} / \mathrm{nap}$ értéket. ${ }^{130} \mathrm{Ha}$ az érték ennél alacsonyabb és/vagy éjszakai hypoglykaemia fordult elő, az adag 2 E-enkénti csökkentése szükséges. A detemirt 2-es típusú diabetesben orális antidiabetikus kezelés kiegészítéseként az esetek többségében napi egyszer elegendő alkalmazni. ${ }^{4}$ Adagolása történhet vacsorakor vagy lefekvés előtt. Ez utóbbi akkor jöhet szóba, ha a korábbi beadás a kívánt éhomi vércukorszintet nem biztosítja. Kezdő adagja és dózistitrálási mechanizmusa lényegében a glargin esetében leírtakkal egyező. Napi egyszeri adása esetén mérsékeltebb testsúlynövekedés várható. Glargin és detemir összehasonlítása során (metformin-kezelés kiegészítéseként, mindkét inzulint napi egyszer adva) mindkét készítmény a glykaemiás kontroll jelentős javulását eredményezte. $\mathrm{A} \mathrm{HbA}_{1 \mathrm{c}}$-csökkenés a glargin esetében volt jelentősebb, a detemir esetében kisebb volt a súlynövekedés és ritkábban fordult elő hypoglykaemia. ${ }^{131}$ A degludek alkalmazása mellett az éjszakai hypoglykaemia kockázata kisebb, mint glargin inzulin adása során.

Inzulinnal korábban nem kezelt betegekben a bázisinzulin tűnik a legkedvezőbb kezdeti kezelésnek. A kombinált kezelés (orális antidiabetikum + inzulin) annál eredményesebb, minél kedvezőbb anyagcserehelyzetben kerül sor bevezetésére. Amennyiben a fenti inzulinadagokkal sem sikerül biztosítani a reggeli normoglykaemiát, és/vagy napközben a vércukorszint meghaladja a $10 \mathrm{mmol} / \mathrm{l}-\mathrm{t}$, célszerü leállítani az esetleges szulfanilurea adását (a metformin megmaradhat) és javasolt áttérni a napjában kétszeri vagy többszöri inzulin adagolására. Megjegyzendő, hogy 10\% feletti kiindulási $\mathrm{HbA}_{1 \mathrm{c}}$ esetén célszerű azonnal inzulinkezelést alkalmazni napi többszöri inzulinadás formájában. A BOT-kezeléstől 8,5\%-os $\mathrm{HbA}_{1 \mathrm{c}}$-érték felett általában kevéssé várható hoszszú távú eredmény. 
Orális antidiabetikum + prandialis (humán reguláris, gyors hatású) inzulin kombinációja

Bár az esetek többségében orális antidiabetikus kezelés inzulinnal történő kiegészítésekor az inzulin adása a bázisinzulin-pótlást szolgálja, kifejezett étkezés(ek) utáni vércukor-emelkedéssel járó esetekben sor kerülhet a metformin + prandialis inzulin kombináció alkalmazására is. Ez a kombináció olyan esetekben választható, amikor az inzulinelválasztást serkentő antidiabetikum adása nem jön szóba, vagy metformin és inzulinszekretagóg hatású szer együttadása a kívánt postprandialis vércukorcsökkenést nem biztosítja, de az éhomi vércukorszint a beállított kezelés mellett elfogadható. Fenti meggondolás alapján metformin és étkezések előtt (prandialisan) alkalmazott gyors hatású inzulinanalóg együtt adása is szóba jöhet azon ritka esetekben, amikor a metformin a kívánt mértékű bázisinzulin-hatást biztosítja, de a postprandialis vércukor-emelkedés kifejezett és más módon biztonságosan nem csökkenthető.

Konvencionális inzulinkezelés humán inzulinnal 2-es típusú diabetes mellitusban

A 2-es típusú diabetesben szenvedő, általában idősebb betegek jelentős része jól kezelhető konvencionális inzulinterápiával, ami általában napjában kétszer adott, bifázisos (gyors és intermedier hatástartamú komponenst 25-30/75-70 arányban tartalmazó) humán inzulin adását jelenti. Ilyen esetekben a reggeli és esti inzulinadagok aránya 2:1 vagy 3:2 szokott lenni. E betegek életmódja, étrendje ugyanis eléggé stabil, a konvencionális kezelés viszonylag könnyen kivitelezhető, az esetek többségében az elért eredmény is megfelelő. ${ }^{97}$

\section{Bifázisos inzulinanalógok adása 2-es típusú diabetesben}

Az inzulinanalógot tartalmazó bifázisos inzulinkészítmények is jól alkalmazhatók a 2-es típusú diabetesesek kezelésére. Adásukra leginkább akkor kerül sor, ha humán inzulint tartalmazó bifázisos inzulinkészítmények adása mellett megfelelő anyagcserehelyzet nem biztosítható. Bár adhatók napjában kétszer, reggel, illetve az esti fóétkezés előtt, egyre inkább terjed a napi háromszori, a három fóét- kezéshez kapcsolódó alkalmazásuk. E kezelésformát intenzív keverékterápiaként (intensive mixture therapy: IMT) vagy prandialis premix kezelésként (prandial premix therapy: PPT) említik. A magas gyorskomponens-arányú változat adása akkor javasolt - általában reggel, az esetek egy részében ebéd előtt is -, ha az érintett személy nagyobb szénhidráttartalmú ételeket fogyaszt. Sok betegben azonban a kezelés bonyolultságának elkerülése érdekében mindhárom fő́tkezést megelőzően azonos összetételű keverék adása tűnik célszerűnek. ${ }^{132,133}$

Szemi-intenzív humán inzulinkezelés 2-es típusú diabetes mellitusban

A betegek egy részében régebben ún. szemi-intenzív kezelési formát választottunk, főleg akkor, ha az étkezések között inkább a vacsora a hangsúlyos. Ilyenkor reggeli előtt humán bifázisos inzulin, délután öt óra körül gyors hatású és lefekvéskor intermedier típusú humán inzulint választunk, amivel a vacsoratáji vércukor-emelkedés jól kivédhető, s a másnap reggeli, éhomi vércukorérték sem magas. Egy másik kezelési lehetőséget jelent a kétszer (reggel-este) adott bifázisos humán inzulin kiegészítése gyors hatású inzulinnal a déli órákban, az ebéd előtt (ha ez az étkezés jelentősebb). A bifázisos inzulinanalógok forgalomba kerülésével a szemi-intenzív humán inzulinkezelés sokat veszített jelentőségéből, alkalmazására ma egyre ritkábban kerül sor.

Intenzív konzervatív inzulinkezelés (ICT) 2-es típusú diabetes mellitusban - szekvenciális intenzifikálás prandialis inzulinanalóggal

A 2-es típusú diabetesben szenvedők esetében is helye van az intenzív konzervatív inzulinkezelésnek (ICT), főleg akkor, ha az adott beteg fiatalabb életkora, foglalkozása, életmódja ezt indokolttá teszi (ekkor érdemes rögtön ezzel a kezelési formával indítani), vagy ha a betegek esetében a korábban alkalmazott inzulinkezelés nem hozta meg a remélt eredményt.

Az inzulinkezelés intenzifikálása prandialis inzulinanalóggal (6. ábra) szekvenciálisan/lépcsőzetesen is megvalósítható, az azonnali teljes bázis-bólus rendszerhez hasonló hatékonysággal és biztonságossággal. Ez a megoldás a nemzetközi gyakorlat- 


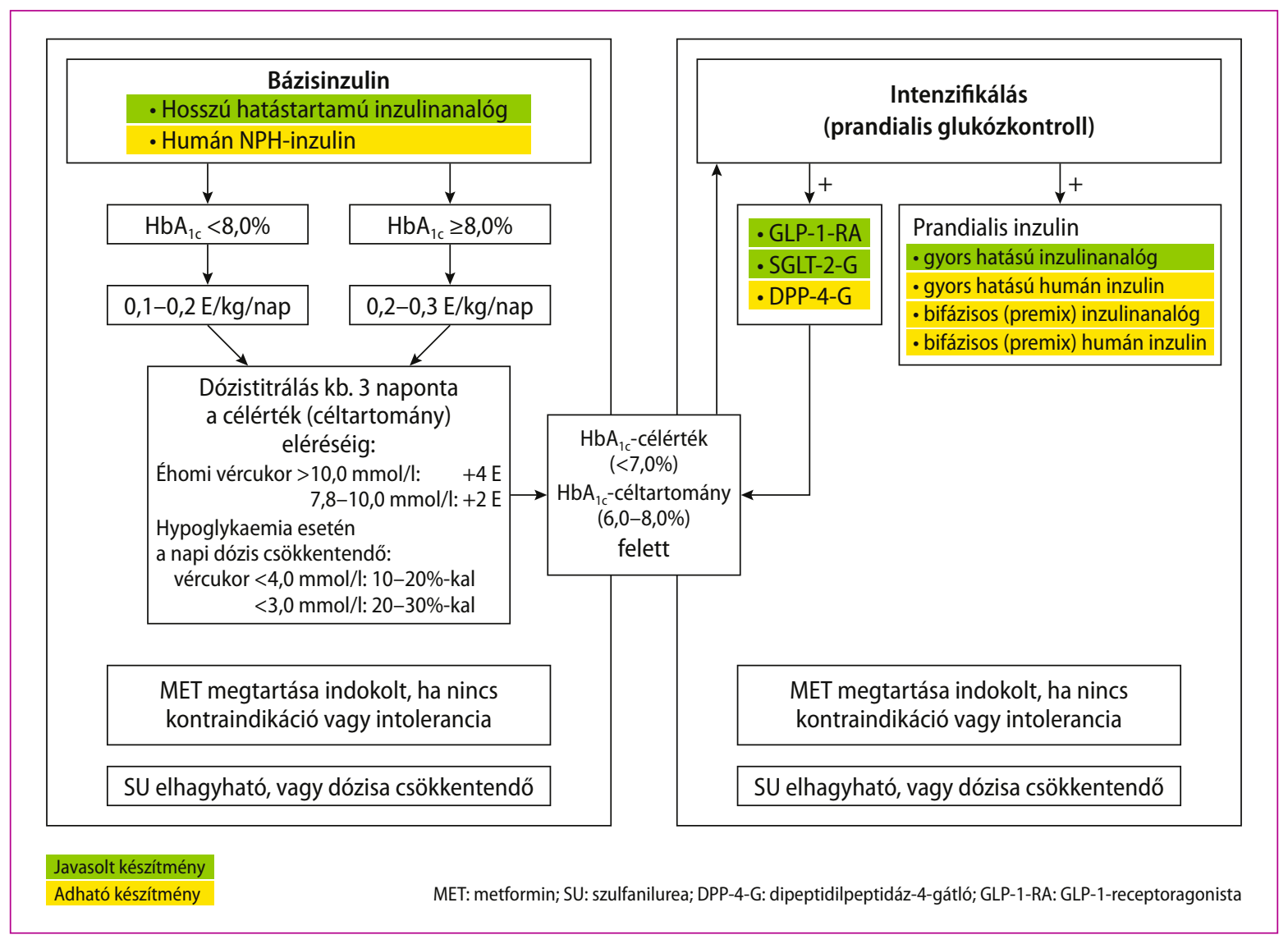

\section{6. ábra. Az inzulinterápia intenzifikálása 2-es típusú diabetesben (kiindulási helyzet: bázisinzulin-terápia)}

ban újabban széles körűen elfogadottá vált. Ilyen esetben az analóg BOT kezelés elégtelensége esetén a prandialis inzulinnal való kiegészítés úgy valósulhat meg, hogy első lépésben egy étkezési inzulininjekcióval egészül ki a bázisinzulin-kezelés, a legnagyobb szénhidráttartalmú étkezés vagy a legnagyobb postprandialis vércukor-emelkedéssel járó étkezés vagy egységesen a reggeli étkezés előtt (bázis plusz kezelésként is szokták említeni). Ha a glykaemiás kontroll nem megfelelő, hasonló módon történik a második és szükség esetén a harmadik étkezés elötti inzulininjekció bevezetése. ${ }^{4}$

\section{Bázisinzulin+ inkretintengelyen ható készítmények szabad kombinációja}

Napjaink egyik új kezelési lehetőségét a bázisinzulin mellett alkalmazott rövid vagy hosszú ha- tású GLP-1-agonisták, ill. DPP-4-gátlók jelentik. Ezek a kezelési rendszerek a bázisinzulin prandialis inzulinnal történő intenzifikálásának alternatíváját jelentik (6. ábra). E kombinált kezelési forma patogenetikai háttere, hogy a bázisinzulin jól kontrollálja az éhomi és étkezési előtti vércukorértékeket, a hozzá adott GLP-1-agonisták vagy DPP-4-gátlók pedig a postprandialis vércukorérték csökkentését biztosítják. ${ }^{134,135}$ A kombináláskor a mindenkori gyógyszer alkalmazási előírásában rögzítettek a mérvadók.

\section{Bázisinzulin+ GLP-1-RA fix kombinációja}

A degludek + liraglutid (bázisinzulin + GLP-1RA) fix kombinációja a bázisinzulin-kezeléshez képest kedvezőbb glykaemiás kontrollt, alacsonyabb hypoglykaemia kockázatot és kedvezőbb 
testsúlyprofilt biztosít. ${ }^{136}$ Kezdő adagja inzulin-naiv betegek esetében 10 adagolási egység, korábban bázisinzulint kapó betegek esetében 16 adagolási egység, mely a megelőző három nap éhomi vércukorérték átlagának megfelelően titrálandó tovább. Ez a kezelési rendszer hatékony alternatíváját jelentheti a bázisinzulin után felépítendő bázis-bolus terápiának 2-es típusú diabetesben $(6$. ábra).

\section{GLP-1-RA + prandialis gyors hatású inzulinanalóg szabad kombinációja}

Az analóg bázis-bólus kezelés alternatívájaként szignifikánsan kedvezőbb glykaemiás kontrollt eredményezve, kedvezőbb testsúlyhatás, kisebb napi teljes inzulinigény és alacsonyabb hypoglykaemia-kockázat mellett számoltak be dulaglutid és naponta többször adott prandialis lispro-inzulin együttes adásáról. ${ }^{137}$

\section{Inzulin + SGLT-2-gátló kombinációja}

Mind bázisinzulin, mind napi többszöri inzulinadás esetén kombinációs lehetőség az SGLT-2-gátló. A kombináció logikus, mivel az inzulin hatását jól kiegészíti az inzulintól független hatásmechanizmusú SGLT-2-gátló, a glykaemiás kontroll javulása a testtömeg és a vérnyomás csökkenésével társul, a hypoglykaemia-kockázat növekedése nélkül. Az empagliflozin estében mind a többszöri inzulinadással, mind a bázisinzulinnal való együttadás klinikai adatait tartalmazza az alkalmazási előírás. ${ }^{138,139}$ A dapagliflozin is adható inzulinnal együtt. ${ }^{140}$

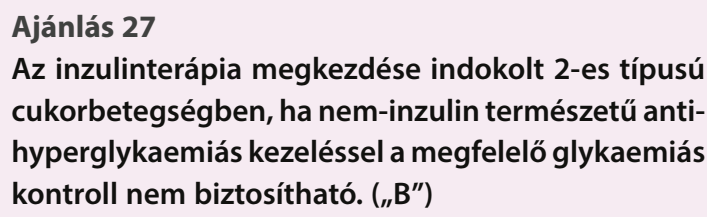

Az inzulinterápia megkezdésével való késlekedés szakmailag nem indokolható. Kétségtelen, hogy a betegek egy része nehezen tud megbarátkozni az inzulinadás gondolatával, de ilyen esetekben a páciensedukáció keretein belül a beteg félelmét el kell oszlatnunk. Több felmérés igazolta, hogy gyakran indokolatlanul hosszú idő telik el rossz glykaemiás helyzetben addig, amíg az inzulinterápia iniciálására sor kerül. A korai inzulinkezelés előnyös voltát újonnan felfedezett 2-es típusú cukorbetegekben is igazolták, ugyanis az alkalmazott átmeneti intenzív inzulinkezeléssel később hosszabb ideig tartó gyógyszermentesség volt elérhető. ${ }^{141,142}$

\section{Ajánlás 28}

A 2-es típusú cukorbetegek inzulinkezelési rendszerében az inzulinanalógokat előnyben kell részesíteni a humán inzulinokhoz viszonyítva. („A")

Az inzulinanalógok előnyét a megfelelő humán kezelési rendszerhez viszonyítva számos terápiás rezsim során igazolták 2-es típusú diabetesben. Gyors hatású inzulinanalógok adása mellett mind a postprandialis vércukorértékek, mind pedig a $\mathrm{HbA}_{1 \mathrm{c}}$ szignifikáns mértékü javulását figyelték meg. ${ }^{143,144}$ A BOT-terápia ma már klaszszikusan bázisinzulin-analóggal zajlik, miután a glarginnal, később a detemirrel folytatott vizsgálatok igazolták NPH-inzulinnal szemben az éjszakai hypoglykaemia-események csökkenését. ${ }^{145} \mathrm{~A}$ degludek előnyösebb volt, mint a glargin mind a BOT-terápiában, mind a bázis-bolus kezelési rendszerben. ${ }^{89,146,147}$ Glargin U300 adása esetén glargin alkalmazásával összevetve azonos glykaemiás kontroll mellett a napi hypoglykaemiás ráta relatív kockázata, valamint a kezelés 8 . hetétől az éjszakai hypoglykaemiák relatív kockázata szignifikánsan csökken. ${ }^{148,149,150,151}$ A glargin és a bioszimiler glargin előírt hasonlóságát megfelelő vizsgálatokkal igazolták. ${ }^{152,153}$ A glargin hosszú távú primer kardiovaszkuláris végpontú vizsgálatban kardiovaszkuláris szempontból biztonságosnak, malignitás szempontjából neutrálisnak bizonyult. ${ }^{154}$ A detemir a glargin inzulinhoz viszonyítva inzulin-naiv betegekben bizonyos fokú testsúlyelőnnyel rendelkezik. ${ }^{155}$

\subsection{Pancreas-és Langerhans-sziget-transz- plantáció}

Csak válogatott esetekben, 1-es típusú diabetesben szenvedők esetében jön szóba transzplantáció a szénhidrát-anyagcsere rendezése érdekében. Sikeres transzplantáció esetén tökéletes normoglykaemia érhető el. 
Ajánlás 29

Szimultán vese- és pancreas-transzplantáció jön szóba olyan 1-es típusú cukorbetegek esetében, akik végstádiumú veseelégtelenség állapotába jutottak és vese-transzplantációra várnak. (, $\left.A^{\prime \prime}\right)$

$\mathrm{Az}$ együttes vese- és pancreas-átültetés eredményei felülmúlják a „csak” pancreas-átültetés eredményeit, mind a graft-túlélés, mind az immunológiai „graft-failure” szempontjából. ${ }^{156} \mathrm{Si}$ keres kombinált vese- és pancreas-transzplantáció esetén megszűnik mind az uraemiás toxikózis, mind a szénhidrátanyagcsere-zavar, elhagyható az inzulin, a diéta és a menetrendszerű életmód, azaz a beteg életminősége és életkilátásai egyaránt jelentősen javulnak. ${ }^{157}$ A microangiopathiás szövődmények közül a nephropathia és a neuropathia javulását írták le, a retinopathia vonatkozásában ellentmondók az eredmények. A makrovaszkuláris szövődmények az esetek egy részében romolhatnak. Transzplantációt követően a beteg tartós - olykor mellékhatásokkal járó - immunszuppresszív kezelést igényel. A műtéti beavatkozás perioperatív mortalitása 3-4\%. ${ }^{156}$ Progressziv nephropathia diabetica esetén a kombinált transzplantáció már $30 \mathrm{ml} / \mathrm{min}$ GFR-érték alatt szóba jön. ${ }^{157}$

A világon eddig mintegy 50000 pancreas-átültetést végeztek, ebből az esetek $75 \%$-a volt szimultán vese- és pancreas-átültetés, $18 \%$-ban végezték a pancreas átültetését a vesetranszplantáció után és az esetek 7\%-ában szoliter pancreas-átültetés történt. ${ }^{156,158}$

Szoliter pancreas-átültetésre hazánkban alig került sor, a beavatkozást más országokban is csak kellően szelektált beteganyagon, szigorú feltételekhez kötötten végzik. Ilyen feltétel a gyakori, meg nem érzett, súlyos (általában tudatzavarral járó) hypoglykaemia (ún. hypoglycemia unawareness syndrome), a „brittle” diabetes, az intenzív inzulinkezelés ellenére is progrediáló proliferatív retinopathia, valamint az ismétlődő, ketoacidosishoz vezetô gastroparesis diabeticorum. ${ }^{157}$

Kontraindikált a pancreas-transzplantáció elvégzése minden pszichiátriai betegség, ill. bizonyított „,non-compliance”, kikezeletlen fertőzés vagy rosszindulatú daganatos elváltozás esetén. Ugyancsak kontraindikált az átültetés szignifikáns peri- fériás obliteratív artériás betegség vagy coronariasclerosis fennállásakor (de ha katéteres tágítással vagy helyreállító érműtéttel a stenosis megoldódott, akkor a transzplantáció elvégezhető). Kontraindikációt képez a jelentős obesitas és a dohányzás is. ${ }^{157}$

\section{Ajánlás 30}

Langerhans-sziget-transzplantáció mérlegelhető azoknál a labilis anyagcseréjü, 1-es típusú cukorbetegeknél, akik már egyéb szervtranszplantációban (pl. vesetranszplantációban) részesültek és immunszupresszív kezelés alatt állnak. („E")

A Langerhans-sziget-transzplantáció során az intervenciós radiológus képernyő alatt katétert vezet a portális vénába és lassú infúzióban bejuttatja az izolált szigeteket tartalmazó tápoldatot. A szövődmények elhanyagolhatók, a beavatkozás szükség esetén ismételhető. A transzplantációt követően tartós immunszuppresszív kezelés szükséges. Az inzulinadás csak a betegek egy hányadában válik tartósan elkerülhetővé. ${ }^{159,160}$ A sziget-graft müködése lényegesen rövidebb, mint a sebészileg átültetett pancreasé.

Langerhans-sziget-transzplantáció indikálásakor gondosan mérlegelni kell a várható előnyt és az elkerülhetetlen (döntően a tartós immunszuppresszív kezeléssel összefüggő) kockázatot.

Nem-immunszupprimált beteg esetében a Langerhans-sziget-transzplantáció indikációja ugyan az, mint a szoliter pancreas-transzplantáció esetén. A kétféle beavatkozás közül a Langerhans-sziget-transzplantáció előnyben részesítendő akkor, ha a beteg általános rossz állapota miatt a nagy hasi műtét túl kockázatosnak tűnik. ${ }^{160}$

\subsection{A súlytöbblet/elhízás kezelése cukorbetegségben}

A túlsúly/elhízás kezelése kiemelt jelentőségű a diabetest megelőző állapotokban és cukorbetegségben. Megszüntetése/mérséklése csökkenti a cukorbetegség előállapotainak diabetesbe történő átmenetelét, mérsékli az inzulinrezisztenciát, javítja a glykaemiás kontrollt, már kialakult diabetesben csökkent(het)i az alkalmazott vércukorcsökkentő gyógyszerek számát és adagját, továbbá mérsékli az ezen állapotokat kísérő keringési 
kockázatot. ${ }^{161,162}$ A kockázat annál nagyobb, minél nagyobb mértékű és minél hosszabb fennállású a súlytöbblet. Legveszélyeztetettebbek a „morbid elhízással” (BMI $\geq 40 \mathrm{~kg} / \mathrm{m}^{2}$ ) rendelkezők. ${ }^{163,164}$

A súlyleadás elősegíthető intenzív életmódkezelés - az étrendi energiatartalom megszorítása és életmódba emelt fizikai aktivitás - bevezetésével $^{165}$ (ld. a 3.1. és a 3.2 fejezetet), ennek kiegészítéseként étvágycsökkentő, illetve különböző tápanyagok felszívódását gátló gyógyszerek alkalmazásával, ${ }^{166}$ valamint manifeszt diabetesben az antidiabetikus kezelés megfelelő megválasztásával. ${ }^{161,162}$ Jelentős súlytöbblet (BMI > 35,0 $\mathrm{kg} / \mathrm{m}^{2}$ ) fennállása és a felsorolt lehetőségek kellő eredményességének elmaradása esetén mérlegelés tárgyát képezheti testsúlycsökkentő mütét, a bariátriai sebészet körébe tartozó eljárás végzése is. ${ }^{161,163,164}$

Bariátriai sebészeten a súlyleadást segítő műtétek összességét értjük. Az idesorolt beavatkozások egy része elsősorban a táplálékfelvételt korlátozza (ún. restrictiv mütét típusok: gyomorszűkítő, illetve megkisebbítő eljárások), más része a felszívó felületet hosszabb-rövidebb bélszakasz kiiktatásával csökkenti (ún. malabsorbtiv műtét típusok). A beavatkozások harmadik formáját a két eljárást kombináló beavatkozások (Roux-Y-gyomor bypass [RYGB], duodenum-szájaztatással [DS] összekötött biliopancreatikus duodenum reversio [BPD]) képezik. A hosszú távon legeredményesebbnek tartott megoldások ez utóbbi csoportba tartoznak. Az eljárások egy része reverzibilis beavatkozást jelent (pl. a laparoscoposan alkalmazható gyomorszűkítés [LAGB]), többségük azonban irreverzibilis változást eredményez. ${ }^{163,164}$

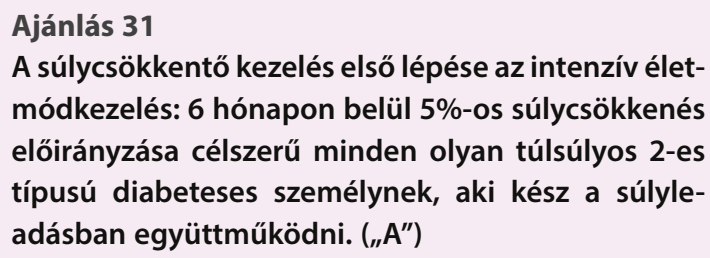

Cukorbetegek minden vizsgálata alakalmával elengedhetetlen a tápláltsági állapot felmérése és az adat betegdokumentációban történő rögzítése. A tápláltsági állapot és az érintett személy test- súlya két ellenőrzés közötti változásának ismerete jelentős orientáló tényező az antidiabetikus kezelés megválasztásában. ${ }^{4,5,161}$ Célszerű a haskörfogat rögzítése is, mivel ez a BMI-nél jobban tájékoztat a hasi zsírszövet nagyságára. A hasi zsírszövet nagysága szorosan korrelál az inzulinrezisztencia mértékével. ${ }^{167}$

A kezelés megtervezéséhez dietetikus igénybevétele szükséges, a súlyleadás ütemét pedig rendszeres ellenőrzésekkel kell követni. Elengedhetetlen feltétel a beteg motivációjának fenntartása, ami magatartásterápia alkalmazásával biztosítható. A kitűzött kezelési cél akkor teljesíthető, ha a napi energiabevitel a szükséglethez képest $500-750$ kcal-val kevesebb. ${ }^{161}$

Azon személyek esetében, akiknél a rövid távú súlyleadás teljesül, a súlycsökkentő kezelés hosszú ( $\geq 1$ év) tartamú folytatása javasolt. Az e programban részt vevők ellenőrzését is havi gyakorisággal kell folytatni. Az anyagcsere-mutatók követése mellett kívánatos a testsúly hetenkénti rögzítése is. A dietetikussal történő konzultációt szükség szerinti gyakorisággal ismételni kell. ${ }^{161}$

Rövid tartamú (3 hónapos) jelentős kalóriamegvonással válogatott betegcsoportban szoros ellenőrzés mellett $>5 \%$ súlycsökkenés is elérhető. A szükséglethez képest napi $\geq 800$ kcal-val csökkentett (ún. igen alacsony energiatartalmú étrend, intenzív életmódkezelés) alkalmazásával jelentős súlycsökkenés érhető el. Ilyen esetekben azonban fokozott ellenőrzés szükséges. A szoros étrend leállításakor nagyobb a visszahízás esélye a kevéssé intenzív programban részt vevőkön tapasztalthoz képest. ${ }^{161}$

Ha helyesen beállított életmód-terápia, a súlytöbbletet figyelembe vevő antidiabetikus kezelés és az elhízás kezelésére alkalmazott kiegészítő gyógyszeres terápia ellenére a kívánt súlyleadás elmarad, a kezelés felülvizsgálata szükséges. A diabetest kísérő betegségek/állapotok kezelésére alkalmazott gyógyszerek közül kiemelt figyelmet kell fordítani azon készítménycsoportokra, amelyek adását súlygyarapodás kísérheti (pl. atipikus antipszichotikumok [clozapin, olanzapin stb.], antidepresszánsok [szelektív szerotonin reuptake gátlók], monoamino-oxidáz-gátlók, glukokortikoidok, progesztineket tartalmazó orális fogamzásgátlók stb.). Egyéb tényezők kizárása esetén mérlegelni kell a súlyleadás elmaradásban felté- 
telezetten szerepet játszó készítmény felváltását is. ${ }^{161}$

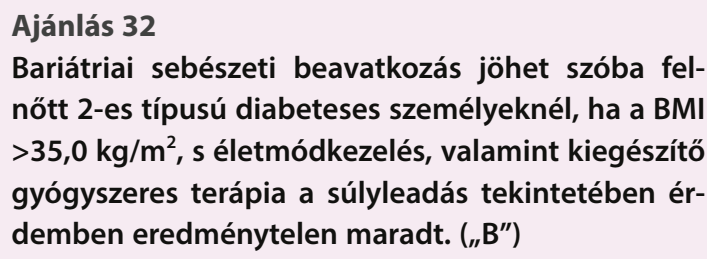

A beavatkozásból a legtöbbet a BMI $>40,0 \mathrm{~kg} / \mathrm{m}^{2}$ értékkel rendelkezők profitálnak, de a beavatkozás szóba jön a BMI $>35,0 \mathrm{~kg} / \mathrm{m}^{2}$ értékkel rendelkezők körében is. ${ }^{168}$

Megfigyelések szerint már a bariátriai műtéteket követő egy-két hét elteltével javul a glykaemiás kontroll, noha ebben az időben a testtömeg és vele együtt, a kedvezőtlen anyagcserehatások szempontjából meghatározó jelentőségű visceralis zsírszövet mennyisége - érdemben még nem változik. A kedvező hatás hétterében hormonális okot tételeznek fel: a GLP-1-elválasztás felerősödését és szekréciójának rövidebb időn belül történő fokozódását valószínűsítik. ${ }^{164,169}$ A glykaemiás kontroll javulása e műtéteken átesett és kiegészítő gyógyszeres kezelésben részesülő személyeknél a vizsgálatok túlnyomó többségében felülmúlta a csak gyógyszerrel kezeltekét. ${ }^{161}$ Számos esetben megfigyelték a diabetes remisszióját is, bár relapsus is előfordulhat. A diabetes remissziójával öszszefüggésben a mikrovaszkuláris szövődmények kialakulásának kockázata is csökken. ${ }^{170}$ Fiatalabb életkor, a 2-es típusú diabetes manifesztálódásától/felismerésétől eltelt rövidebb idő, a beavatkozás előtti alacsonyabb $\mathrm{HbA}_{1 \mathrm{c}}$-érték, magasabb szérum inzulintartalom, valamint inzulin nélküli antidiabetikus kezelés növeli a diabetes remiszsziójának esélyét. ${ }^{161,171}$ Prediabeteses személyeken végzett beavatkozások esetén szignifikáns mértékben csökkent az új diabetes-esetek előfordulása. ${ }^{171}$ A teljesség kedvéért meg kell jegyezni, hogy noha ismertek beszámolók a bariátriai műtétek anyagcsere-javító hatásáról morbid elhízással társult 1-es típusú diabetesben is, e diabetes-típusban elegendő számú és követési tapasztalat még nem áll rendelkezésre megfelelő következtetések levonásához. ${ }^{161}$

A bariátriai sebészeti beavatkozások költsége magas és van kockázatuk is van: laparoscopos eljárások 30 napos halálozása $0,2 \%$ (egyezik más laparoscopos műtétekével), nyílt mütétek esetében azonban 2,1\%. A beavatkozás eredményessége függ a műtét típusától (13. táblázat) és a sebész gyakorlottságától. ${ }^{161,164,172,173}$

Posztoperatív mellékhatásként émelygés, híg széklet, dumping szindróma, hypoglykaemia, hosszabb távon hypovitaminosis (A-, E-, $\mathrm{K}-, \mathrm{B}_{1^{-}}, \mathrm{B}_{12^{-}}$, folsav-, 1,25-dihidroxi-kolekalciferol hiány és következményeikként osteopenia, osteoporosis, paraesthesiák megjelenése, szürkületi homályos látás, hyperparathyreosis, hyperhomocysteinaemia) fordulhat elő. Az enteralis oxalátfelszívódás fokozódása hyperoxaluriát, oxalátkövek kialakulását segítheti elő. Fokozód-

13. táblázat. Az elhízás konzervatív kezelése és a súlyleadást segítő mütétek kimeneti mutatói több vizsgálat ${ }^{4,14,15,16}$ adatai alapján

\begin{tabular}{|c|c|c|c|c|}
\hline & $\begin{array}{c}\text { Életmódkezelés } \\
\text { és gyógyszeres } \\
\text { terápia }\end{array}$ & $\begin{array}{c}\text { Laparoscopos } \\
\text { gyomorszükítés* }\end{array}$ & $\begin{array}{c}\text { Roux-Y gyomor } \\
\text { bypass** }\end{array}$ & $\begin{array}{c}\text { Duodenum- } \\
\text { szájaztatással összekötött } \\
\text { biliopancreatikus } \\
\text { duodenum diversio** }\end{array}$ \\
\hline Súlyvesztés a többletsúly százalékában & $\approx 4-5^{* * *}$ & $50-69$ & 68 & 72 \\
\hline Kétéves súlytartás (\%) & $\approx 0-6^{* * * *}$ & 48 & 62 & 70 \\
\hline 2-es típusú diabetes remissziója (\%) & $\approx 0-13$ & $48-68$ & 84 & 98 \\
\hline Hypertonia rendeződése (\%) & nincs pontos adat & $38-73$ & 75 & 100 \\
\hline Dyslipidaemia javulása (\%) & nincs pontos adat & $71-81$ & 94 & 1,1 \\
\hline Mútéti halálozás (\%) & & 0,1 & 0,5 & 100 \\
\hline
\end{tabular}

* restrictiv beavatkozás

** kombinált, restrictiv és malabsorbtiv műtét

*** a kiindulási súly százalékában

**** becsült adat 
hat az epe lithogenitása, ami epekövesség gyakoribb előfordulását eredményezheti. Egyes vizsgálatok alkoholizmus és drogfogyasztás gyakoribbá válását figyelték meg az e műtéteken átesettek körében. ${ }^{161}$

A bariátriai mütéten átesett 2-es típusú diabeteses személyek életen át tartó követést és legalább évenkénti orvosi ellenőrzéseket igényelnek. A beavatkozások túlnyomó többsége irreverzibilis anatómiai változásokat eredményez. A kívánt anyagcsere-javulás és súlyleadás elmaradása vagy kisebb mértéke, továbbá a műtétet követő mellékhatások tartós előfordulása ezért az érintett személy számára fokozott pszichés megterhelést jelenthet. Éppen ezért kiemelt jelentőségű az alkalmas személyek kiválasztása. A beavatkozások mérlegelésének sebészi szempontjait a 14. táblázat foglalja össze. ${ }^{164,174}$

Bár több kisebb vizsgálat igazolta bariátriai mütétek kedvező glykaemiás és keringési kockázat csökkentő hatását 30,0-35,0 kg/m² közötti BMIértékkel rendelkező 2-es típusú diabeteses személyeken is, jelenleg kevés a bizonyíték arra, hogy e beavatkozások $\leq 35,0 \mathrm{~kg} / \mathrm{m}^{2}$ BMI esetében is biztonsággal ajánlhatók legyenek.

\subsection{Diabetes és várandósság}

A diabetes mellitus a terhességhez társuló egyik leggyakoribb kóros állapot. Irodalmi adatok szerint a fogamzóképes korú nők 0,3\%-a cukorbeteg. $\mathrm{Az}$ esetek egy részében a diabetes már a terhességet megelőzően is fennáll. Ez az ún. pregesztációs diabetes képezi az összes esetek mintegy $10 \%$-át. A nagyobb hányadot - 90\%-ot - a gesztációs diabetes mellitus (GDM) képezi, azaz a cukorbetegség felismerésére a terhesség idején kerül sor. Ez utóbbi állapot a szülést követően reklasszifikációt igényel: az esetek egy részében a szénhidrát-anyagcsere normalizálódik, más részében IGT, ritkábban manifeszt diabetes mellitus marad vissza. Tekintettel arra, hogy az aktuálisan rendezett anyagcserehelyzetű asszonyok is egy következő terhesség szempontjából, illetve - ettől függetlenül - életük egész tartama során diabetesre fokozottan veszélyeztetettnek tekintendők, követésük és szénhidrát-anyagcseréjük időszakos ellenőrzése elengedhetetlen követelmény.
14. táblázat. Bariátriai mütétre való alkalmasság sebészi szempontjai ${ }^{164,174}$

- BMI $>35,0 \mathrm{~kg} / \mathrm{m}^{2 *}$

- Életkor 16-65 év

- Konzervatív fogyókúrás eljárások dokumentált

eredménytelensége

- Vállalható mútéti kockázat

- Stabil pszichéjú személy

- Kellő informáltság és a tartós súlyleadás iránti motiváció megléte

- Elkötelezettség az életmódváltás iránt

- Támogató családi/szociális háttér

- Együttműködési készség a hosszú távú követés vonatkozásában

- Aktív stádiumú skizofrénia és kezelést igénylő depresszió hiánya

* Az eredeti ajánlásban $B M I>40,0 \mathrm{~kg} / \mathrm{m}^{2}$, vagy $>35,0 \mathrm{~kg} / \mathrm{m}^{2}$ és keringési szövődmények fennállása szerepelt, újabb összeállitások a BMI >35,0 kg/m² értéket adják meg

Prekoncepcionális gondozás, pregesztációs diabetes

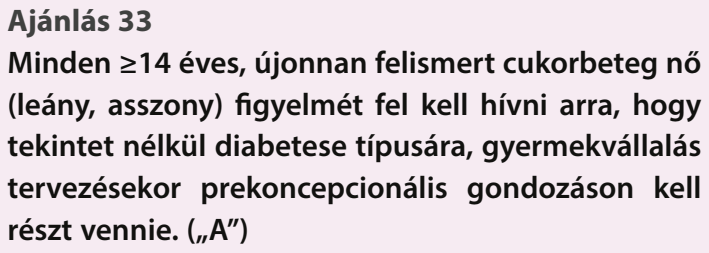

A prekoncepcionális gondozás célja a leendő anya és a születendő gyermek lehető legjobb egészségi állapotának biztosítása, a terhesség anyai és magzati szövődményeinek - elsősorban a fejlődési rendellenességek kialakulásának - megelőzése. A beteg ezzel kapcsolatos felvilágosítása az őt először észlelő vagy gondozó orvos feladata. Az érintett személlyel rendszeres kapcsolatot tartó orvos - háziorvos, gyermekorvos, belgyógyász - feladata a megfelelő gondozóhelyre történő irányítás is. A prekoncepcionális gondozást a kívánt terhességet megelőző fél-egy évvel korábban kell elkezdeni. A gondozást minden esetben e téren jártassággal és megfelelő interdiszciplináris szakmai háttérrel rendelkező centrumban kell végezni. ${ }^{28,175}$ Generatív korú, gyermeket aktuálisan nem kívánó cukorbeteg nő számára tanácsolni kell biztonságos fogamzásgátlás alkalmazását.

Minden pregesztációs, gyermeket kívánó vagy várandóssá vált diabeteses nő figyelmét fel kell 


\section{7. táblázat. A várandósság szakmai szempontok alapján nem tanácsolt cukorbetegségben}

- Kezelésre nem reagáló, látást veszélyeztető proliferatív
retinopathia
- A vesefunkció csökkenését eredményező előrehaladott
nephropathia
- Panaszokat okozó gastroparesis
- Súlyos ischaemiás szívbetegség
- Magas glikált hemoglobinszint a koraterhességben $\left(\mathrm{HbA}_{1 \mathrm{c}}>10 \%\right)$
- Diabeteses ketoacidosis a koraterhességben
- 38 évesnél idősebb cukorbeteg nő, 2 gyermekkel
- Tinédzser diabetika nem tervezett terhessége

ségügyi ellátórendszer feladata a legoptimálisabb gondozás biztosítása.

\section{Gesztációs diabetes mellitus (GDM)}

A terhesség alatt felismeretlenül maradó emelkedett vércukorszint az anyát és magzatot egyaránt veszélyezteti. Anyai oldalról gyakrabban alakul ki preeclampsia-toxaemia, intrauterin elhalás, koraszülés, magzati oldalról születési időre számított nagy súly (large for gestational age: LGA), szülési trauma, újszülött kori hypoglykaemia, hypocalcaemia, respiratorikus distress szindróma, hyperbilirubinaemia. ${ }^{177}$ GDM után 10 évvel közel $50 \%$ a diabetes kialakulásának kockázata. ${ }^{178}$ GDM-es anyák gyermekeinél nő a fiatalkori elhízás, az IGT és a diabetes rizikója is. ${ }^{176,177}$ Mindezen okok folytán a terhesség alatti szénhidrátanyagcsere-zavarok időben történő felismerése alapvető jelentőségü.

\section{Ajánlás 34 \\ A gesztációs diabetes mellitus (GDM) időben törté- nő felismerése céljából teljes körű terhességi diabe- tes-szürést kell végezni. („A")}

A jelenleg hatályos nemzeti és nemzetközi ajánlások egységesek a teljes körű terhességi diabetes-szűrés tekintetében, de részben különböznek az alkalmazandó módszert illetően. Számos tudományos társaság - új irodalmi adatok ${ }^{179}$ nyomán kifejtette álláspontját, ${ }^{1,2,180,181,182,183,184,185,186} \mathrm{e}$ helyen az MDT által elfogadott (de egy év múlva felülvizsgálni javasolt) állásfoglalást ${ }^{177}$ ismertetjük.

A szűrés ajánlott menetét, a GDM-re utaló vércukor-határértékeket a 18. táblázat mutatja be. A diabetes tekintetben fokozott kockázatot jelző ál-
18. táblázat. Gesztációs diabetes mellitus (GDM) szürése (az MDT Terhesdiabetológiai Munkacsoportja hatályos állásfoglalása ${ }^{177}$ )

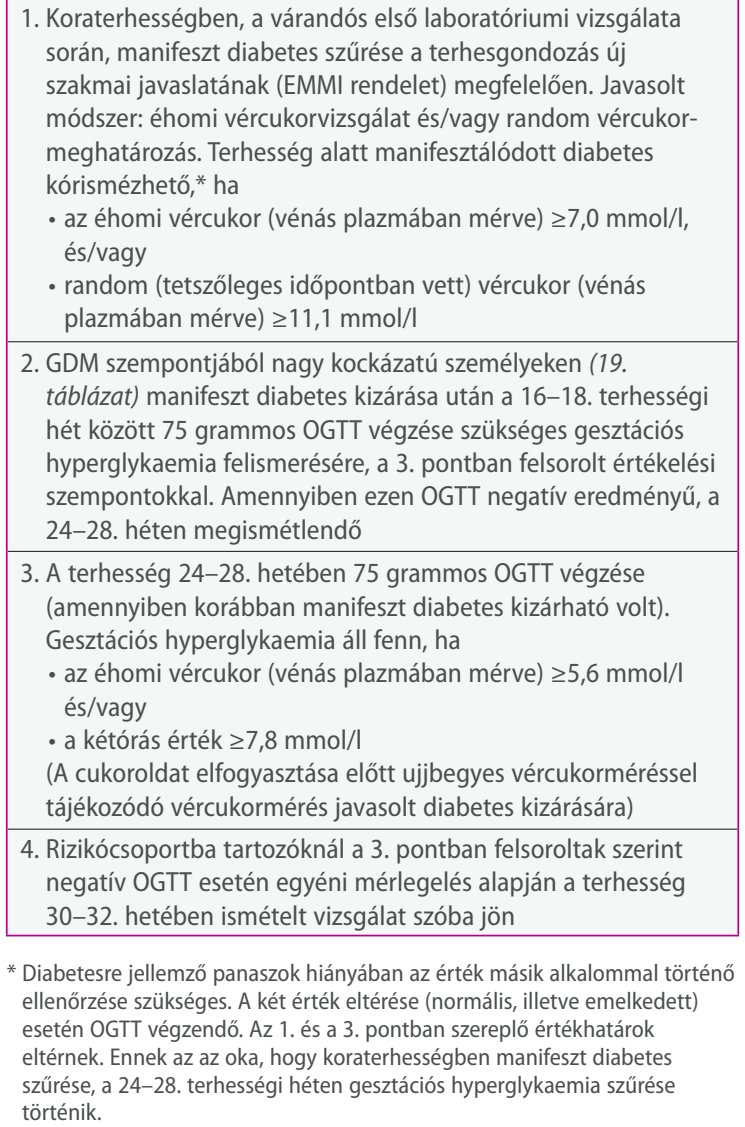

1. Koraterhességben, a várandós első laboratóriumi vizsgálata során, manifeszt diabetes szürése a terhesgondozás új szakmai javaslatának (EMMI rendelet) megfelelően. Javasolt módszer: éhomi vércukorvizsgálat és/vagy random vércukormeghatározás. Terhesség alatt manifesztálódott diabetes kórismézhető, ${ }^{*}$ ha

- az éhomi vércukor (vénás plazmában mérve) $\geq 7,0 \mathrm{mmol} / \mathrm{l}$, és/vagy

- random (tetszőleges időpontban vett) vércukor (vénás plazmában mérve) $\geq 11,1 \mathrm{mmol} / \mathrm{l}$

2. GDM szempontjából nagy kockázatú személyeken (19. táblázat) manifeszt diabetes kizárása után a 16-18. terhességi hét között 75 grammos OGTT végzése szükséges gesztációs hyperglykaemia felismerésére, a 3. pontban felsorolt értékelési szempontokkal. Amennyiben ezen OGTT negatív eredményű, a 24-28. héten megismétlendő

3. A terhesség 24-28. hetében 75 grammos OGTT végzése (amennyiben korábban manifeszt diabetes kizárható volt). Gesztációs hyperglykaemia áll fenn, ha

- az éhomi vércukor (vénás plazmában mérve) 25,6 mmol/l és/vagy

- a kétórás érték $\geq 7,8 \mathrm{mmol} / \mathrm{l}$

(A cukoroldat elfogyasztása előtt ujjbegyes vércukorméréssel tájékozódó vércukormérés javasolt diabetes kizárására)

4. Rizikócsoportba tartozóknál a 3. pontban felsoroltak szerint negatív OGTT esetén egyéni mérlegelés alapján a terhesség 30-32. hetében ismételt vizsgálat szóba jön

* Diabetesre jellemző panaszok hiányában az érték másik alkalommal történő ellenőrzése szükséges. A két érték eltérése (normális, illetve emelkedett) esetén OGTT végzendő. Az 1. és a 3. pontban szereplő értékhatárok eltérnek. Ennek az az oka, hogy koraterhességben manifeszt diabetes szűrése, a 24-28. terhességi héten gesztációs hyperglykaemia szűrése történik.

19. táblázat. Gesztációs diabetes mellitus (GDM) szempontjából fokozott kockázatú egyének

- Anyai életkor $>35$ év

- BMI $>30 \mathrm{~kg} / \mathrm{m}^{2}$

- Diabetes előfordulása az első fokú rokonok között

- Anamnézisben korábbi szénhidrátanyagcsere-zavar

- Terhelő szülészeti anamnézis (halvaszülés, koraszülés, méhen belüli elhalás, fejlődési Rendellenességgel világra hozott gyermek, >4000 g-os, illetve terhességi korra számított nagy magzat világrahozatala)

- Ikerterhesség hordozása

- Asszisztált reprodukcióval létrejött terhesség

lapotokat - ahol már koraterhességben is indokolt OGTT végzése - a 19. táblázat foglalja össze. 
Ajánlás 35

A gesztációs diabetes mellitus (GDM) vércukorcsökkentő kezelésének első lépéseként megfelelő étrend és életmód kialakítását (életmódkezelést) kell tanácsolni. („A")

A GDM-es esetek többségében életmódkezelés kvantált, szénhidrát- és energiatartalmában meghatározott, napi 5-6 alkalomra elosztott étrend, valamint a terhelhetőséghez/edzettséghez igazodó napi gyakoriságú fizikai aktivitás, a testsúly kontrollja - elegendő a kívánt glykaemiás állapot eléréséhez és fenntartásához (16. táblázat). A megfelelő étrend célja az anya és a magzat számára szükséges tápanyagok biztosítása, normoglykaemia fenntartása mellett. A ketonuria/ketonaemia elkerülése érdekében az első trimesterben testsúlytól függően napi 140-160 gramm szénhidrát, kb. 1500-1600 kcal (6300-6720 kJ) energia bevitele szükséges. Bár a szokásos napi energiafelvételt 22-35 kcal/testsúlykg között tartják optimálisnak, a GDM-es terhesek gyakori túlsúlyára tekintettel az esetek jelentős részében ennél kisebb energiabevitel, a terhesség előtti testsúly függvényében akár $12 \mathrm{kcal} /$ testsúlykg-ig terjedő megszorítás lehet szükséges. A második trimestertől kezdve a naponta beviendő energia szükséglete 250-300 kcal-val (1050-1260 kJ) nő. Az étrend ajánlott öszszetétele nem különbözik a nem-terhes cukorbetegek részére is tanácsolttól. ${ }^{28,176}$

A gyakori, alkalmanként kis szénhidráttartalmú étkezések az étkezés utáni vércukorcsúcs mérséklését szolgálják. A reggeli és a tízórai szénhidrátelosztása a nem-terhesek számára ajánlottól eltér: itt reggelire valamivel kevesebb, tízóraira a reggelivel azonos mennyiségű, vagy valamivel több szénhidrát fogyasztása ajánlott. Cél, hogy a terhesség alatti testsúly növekedése ne legyen több 8 kg-nál. A teherbíró képességhez igazodó fizikai tevékenység GDM-ben is kifejezetten ajánlott. Javítja az anyagcserehelyzetet, csökkenti a macrosomia elöfordulását, de nem igazolták a császármetszések számát csökkentő hatását. ${ }^{28}$

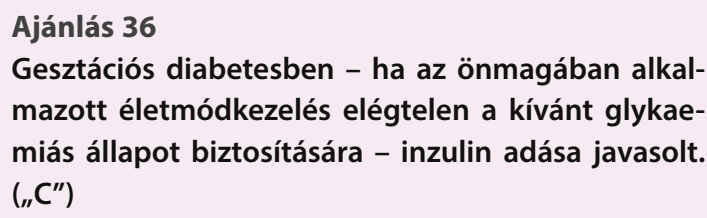

Bár a tengerentúli ajánlások megengedik GDMben metformin (terhességi B osztály), illetve glibenclamid (terhességi B osztály) adását is, ${ }^{175}$ a hazai gyakorlat nem támogatja vércukorcsökkentő tablettás kezelés alkalmazását terhességben. ${ }^{28,176}$ Mindkét említett szer ugyanis átjut a placentán, a metformin megjelenik az anyatejben is. Terhességben történő adásukkal hosszú távú biztonságossági adatok ez idő szerint nem állnak rendelkezésre. ${ }^{175}$

Mivel a GDM-es esetek többségében közel normális éhomi vércukorszint mellett kifejezett az étkezést követő vércukorszint emelkedése, ha az életmódkezelés nem biztosítja a kívánt glykaemiás kontrollt, napi 1-3, főétkezések előtt (prandialisan) adandó humán gyors hatású inzulin bevezetése javasolt. (Előfordulhat, hogy csak reggel, máskor reggel és a vacsorához szorulunk inzulin adására.) Ha az éhomi vércukorszint is emelkedett, szükség lehet bázisinzulin, elsősorban humán NPH készítmény adagolására is. Ez utóbbi kezdőadagjaként 4-8 E adása javasolt. Két, reggel és lefekvéskor adott „bázis”-inzulin adása az inzulinhatások potenciális interferenciája folytán nem ajánlott. Inzulinkezelés esetén a normoglykaemia eléréséhez szükséges inzulinadag napi 6-7 vércukorméréssel titrálható ki, a napi inzulinigény még túlsúlyos várandósokon sem nagy (átlagosan 12-24 E). GDM-ben csak elvétve kényszerülünk az 1-es típusú diabetesben nem ritka napi 5-7-szeri humán gyors hatású inzulin alkalmazására (ilyen esetekben feltehetően az 1-es típusú diabetes késői manifesztálódásáról van valójában Szó). ${ }^{176}$

Inzulinanalógok adása terhességben általában nem tanácsolható. A kifejezett, étkezést követő vércukor-emelkedési tendencia miatt ugyanis kívánatos minél gyakoribb étkezések alkalmazása. Az analóg inzulinokkal végzett kezelési rendszerekben a napi étkezések szokásos száma három, ami esetenként jelentős postprandialis vércukor-emelkedést okozhat. Az analóg prandialis inzulinok közül az aszpart és a lispro az FDA terhességi „B”, a glulisin terhességi „C”, az analóg bázisinzulinok közül a levemir terhességi „B”, a glargin terhességi „C” kategóriájú. ${ }^{187}$ Inzulinpumpa-kezelés alkalmazását GDM-ben semmilyen megfontolás nem támogatja. Önmagában a terhesség nem indikáció a pumpakezelés megkezdésére pregesztációs cukorbetegségben sem, de inzulinpumpán lévő pre- 
gesztációs cukorbetegek pumpakezelése rendezett anyagcsere-állapot esetén folytatható. ${ }^{28,176}$

\section{Ajánlás 37}

Gesztációs diabetes esetén a szülést követően - leghamarabb a szülés után 6-12 héttel - az anyagcsere ismételt vizsgálata szükséges (reklasszifikáció). („A")

A GDM későbbi diabetes fokozott kockázatát jelző állapot. Fontos az anyagcsere tisztázása már a szülést követően. A reklasszifikáció eszköze az OGTT, amelyet két időpontban, a 0 . és a 120 . percben vett minta vércukorszintjének meghatározásával kell végezni. ${ }^{28,176} \mathrm{Az}$ értékelés a nem-terhes állapotban szokásos határértékekkel történik. Tekintettel arra, hogy a vörösvértestek turnovere még a szülést követő időszakban is fokozott, a $\mathrm{HbA}_{1 c}$-érték megtévesztően alacsony lehet, ezért ilyenkor a szénhidrát-anyagcsere megítélésére nem alkalmas. ${ }^{28}$

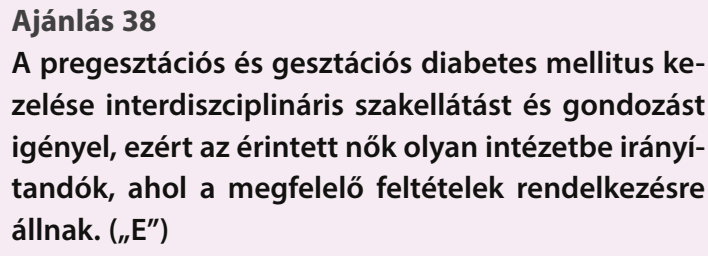

A pregesztációs és gesztációs diabetes mellitus kezelése team-munkát igényel, ami során az előzőekben említetteken túlmenően az alábbi körülményekre is figyelemmel kell lenni.

\section{Vérnyomás}

Normotensiv személyeken terhességben a vérnyomás kis mértékben csökken a nem-terhes állapothoz képest. Terhesség során felismert, illetve krónikus hypertoniás személyek kezelési célértéke 110-129 Hgmm-es systolés, illetve 65-79 Hgmm-es diastolés érték. Az ennél alacsonyabb érték az uteroplacentaris keringést veszélyeztetheti. ${ }^{175}$ Terhességben a vérnyomás kezelésére elsősorban methyldopa választandó, ennek kiegészítésére adható labetalol, diltiazem, clonidin és prazozin is. Diuretikumok rendszeres adása kerülendő, mert csökkenti az anyai plazmavolument és károsíthatja az uteroplacentaris perfusiót. ${ }^{175,188}$ A potenciálisan teratogén ACE-gátlók és ARB csoportú szerek nem alkalmazhatók terhesség alatt.

\section{Lipidértékek}

A terhesség LDL-koleszterin és trigliceridszint emelkedéssel jár, utóbbi azonban 11,0 mmol/l-es értékéig gyógyszeres kezelést nem igényel. Familiaris hypercholesterinaemia fennállásakor legfeljebb epesav-kötő gyanták adása engedhető meg a koleszterinszint gyógyszeres csökkentéseként. A $>11,0 \mathrm{mmol} / \mathrm{l}-\mathrm{t}$ meghaladó trigliceridszintel járó állapotok gyógyszeres kezelése azonos a nem-terhes állapotban követendővel. ${ }^{188}$ Bár több, változó esetszámú kohorsz vizsgálatban az első trimesterben adott statinok teratogén hatása nem volt megerősíthető, prospektív-randomizált vizsgálatok hiányában e gyógyszercsoport adása terhességben ellenjavallt. ${ }^{188,189}$

Vércukormérés, $\mathrm{HbA}_{1 c}$-mérés

Mind pregesztációs, mind gesztációs diabetesben az éhomi, a pre- és a postprandialis vércukorértékek szoros követése kívánatos. Rendszeres időközönként javasolt a hosszabb távú anyagcserehelyzet ellenőrzése is. $\mathrm{A} \mathrm{HbA}_{1 \mathrm{c}}$-érték tekintetében - a hypoglykaemia-kockázat csökkentése érdekében - a 6,0-6,5\% közötti tartomány elérésére célszerű törekedni. Megengedhető a <6,0\%-os érték célul kitűzése, ha a nem kívánt vércukoresés biztosan elkerülhető és a várandós szoros ellenőrzése biztosított. Indokolt esetben $<7,0 \%$-os $\mathrm{HbA}_{1 \mathrm{c}}$-érték is elfogadható, ha az ennél szorosabb célérték esetén hypoglykaemiák fordulnak elő. ${ }^{175}$ Miután terhességben a vörösvérsejtek turnovere felgyorsult (az alacsonyabb félélet-idő miatt a $\mathrm{HbA}_{1 c}$-érték alacsonyabb lehet a nem-terhes állapothoz képest), a $\mathrm{HbA}_{1 \mathrm{c}}$-érték helyett a megelőző 2-3 hét átlagos vércukorszintjét tükröző szérum fruktózamin mérése javasolt. ${ }^{28,175}$

\subsection{Vércukor-önellenőrzés cukorbetegségben}

A vércukor-önellenőrzés (angol nyelvű irodalomban SMBG: self-monitoring of blood glucose) jelentősen segíti a cukorbeteget és kezelőorvosát, miután az

- az aktuális vércukorértékről tájékoztat késedelem nélkül,

- lehetővé teszi az éhomi (étkezés előtti) és postprandialis vércukor meghatározását, 
20. táblázat. A vércukor-önellenörzés céljai 1-es és 2-es típusú diabetesben ${ }^{35}$

\begin{tabular}{|c|c|c|}
\hline Speciális célok & 1-es típusú diabetes & 2-es típusú diabetes \\
\hline $\begin{array}{l}\text { Éhomi/étkezés előtti és postprandialis } \\
\text { vércukor mérése }\end{array}$ & $\checkmark$ & $\checkmark$ \\
\hline Inzulindózis változtatása & $\checkmark$ & $\checkmark$ inzulinnal kezeltek körében \\
\hline Hypoglykaemia megelőzése & $\checkmark$ & $\begin{array}{c}\checkmark \text { inzulinnal vagy szulfanilureával kezeltek } \\
\text { körében }\end{array}$ \\
\hline $\begin{array}{l}\text { Fokozottabb ellenőrzés fizikai aktivitás, } \\
\text { interkurrens betegség esetén }\end{array}$ & $\checkmark$ & $\checkmark$ \\
\hline Silent hypoglykaemia felismerése & $\checkmark$ hypoglykaemia-érzéketlenség esetén & - \\
\hline $\begin{array}{c}\text { Vércukor hirtelen változásának felismerése, } \\
\text { annak gyanúja esetén }\end{array}$ & $\checkmark$ & $\checkmark$ \\
\hline
\end{tabular}

- növeli a kezelés biztonságát a hypoglykaemia felismerése révén,

- segítséget jelent az antidiabetikus kezelés szükség szerinti módosításának eldöntésében, ill. annak elfogadásában,

- rendszeres használat eredményeként hozzájárulhat az anyagcserehelyzet javulásához és a késői szövődmények mérsékléséhez.

A vércukor-önellenőrzés céljait 1-es és 2-es típusú diabetesben a 20. táblázat foglalja össze. ${ }^{35}$

A rendszeres vércukor-önellenőrzést végzők gondozását tovább segíti az internetalapú, telemedicinális rendszer, amely átlagok, tendenciák, mérési naplók, grafikonok, statisztikai adatok megjelenítésével támogatja a minél jobb glykaemiás kontroll elérését. ${ }^{190,191}$

\section{Ajánlás 39 \\ A vércukor-önellenőrzés minden cukorbeteg szá- mára ajánlott a diabetes-gondozás keretén belül. $($ („E")}

A vércukor-önellenőrzés lehetőségének kifejlesztését és fokozatos térnyerését követően csak néhány évnek kellett eltelnie ahhoz, hogy a módszer hazánkban is a cukorbeteg-gondozás szerves részévé váljon. ${ }^{192}$ A vércukor-önellenőrzés segíti mind az 1-es típusú, mind a 2-es típusú diabetesben szenvedőket a hypoglykaemiás epizód felismerésében, a hyperglykaemiás anyagcsere-kisiklás időben történő azonosításában, az antidiabetikus terápia aktuális élethelyzethez történő igazításában. A vércukor-önellenőrzés alapvető fontosságú gesztációs diabetes esetén is (ld. 3.6. fejezet). Széles körű szakmai vita után ma úgy látjuk, hogy a rendszeres vércukor-önellenőrzés 1-es típusú és inzulinnal kezelt 2-es típusú diabetesben jobb anyagcserehelyzetet eredményez, ami a szövődmények visszaszorításához vezethet. Inzulinnal nem kezelt 2-es típusú diabetesben a szervezett, ún. strukturált vércukor-önellenőrzés - a betegoktatás részeként - szintén jobb anyagcserehelyzetet eredményezhet. ${ }^{193,194,195,196}$ Mindezek miatt a vércukor-önellenőrzést a cukorbetegek egyre szélesebb köre, gyakorlatilag minden cukorbeteg számára ajánljuk. ${ }^{28}$

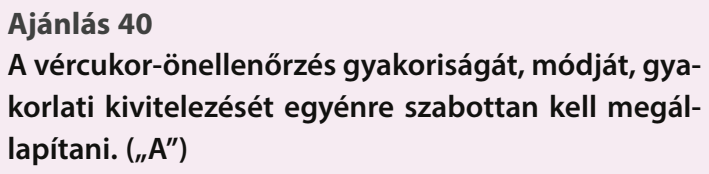

A vércukor-önellenőrzés gyakorlati ajánlása igazodik a diabetes típusához és a választott terápiához. ${ }^{35,36}$ Fontos mérlegelendő körülmény, hogy az adott terápia növeli-e a hypoglykaemia kockázatát vagy sem. Cukorbetegek gondozása során alapvető körülmény az egyéni tulajdonságokat figyelembe vevő kezelési elv, amely a vércukor-önellenőrzés egyénre szabott voltát is jelenti.

\section{1-es típusú diabetes}

Alaphelyzetben naponta indokolt a mérés éhomra, étkezések előtt, étkezések után és lefekvéskor. További mérés indokolttá válhat inzulinpumpa használatakor, hypoglykaemia-érzéketlenség esetén, gépjárművezetéskor, fizikai aktivitás, interkurrens betegség, terhesség esetén, ill. a napi szokásos életmód megváltozásakor. ${ }^{35}$ 


\section{2-es típusú diabetes, inzulinterápia}

- Bázis-bolus kezelési rendszer: az elv azonos az 1-es típusú diabetesnél leírtakkal.

- Premix inzulin: alaphelyzetben éhomi mérés naponta, egy további mérés lépcsőzetesen változó időpontban. További mérések indokolttá válnak szulfanilurea-terápia, hypoglykaemia tünetei, gépjárművezetés, fizikai aktivitás, terhesség, napi szokásos életmód megváltozása, ill. magas $\mathrm{HbA}_{1 \mathrm{c}}$-érték esetén.

- Bázisinzulin: alaphelyzetben éhomi vércukor naponta, egy étkezés utáni vércukor naponta, lefekvés előtti mérés hetente. További mérések indokolttá válnak szulfanilurea-terápia, hypoglykaemia tünetei, gépjárművezetés, fizikai aktivitás, terhesség, napi szokásos életmód megváltozása, ill. magas $\mathrm{HbA}_{1 c}$-érték esetén.

\section{2-es típusú diabetes, inzulinterápia nélkül}

- Monoterápiás vagy kombinációs kezelés, amelyben szulfanilurea vagy glinid szerepel: alaphelyzetben napi egyszeri mérés és heti egyszeri rövid profil. További mérések indokolttá válnak hypoglykaemia tünetei, gépjárművezetés, fizikai aktivitás, terhesség, napi szokásos életmód megváltozása, ill. magas $\mathrm{HbA}_{1 \mathrm{c}}$-érték esetén.

- Monoterápiás vagy kombinációs kezelés szulfanilurea vagy glinid nélkül: alaphelyzetben heti egyszeri rövid profil. További mérések indokolttá válnak hypoglykaemia tünetei, fizikai aktivitás, terhesség, ill. magas $\mathrm{HbA}_{1 c}$-érték esetén.

- Életmód-terápia: alaphelyzetben havonta egy rövid profil. További mérések indokolttá válnak hypoglykaemia tünetei, fizikai aktivitás, interkurrens betegség, terhesség esetén.

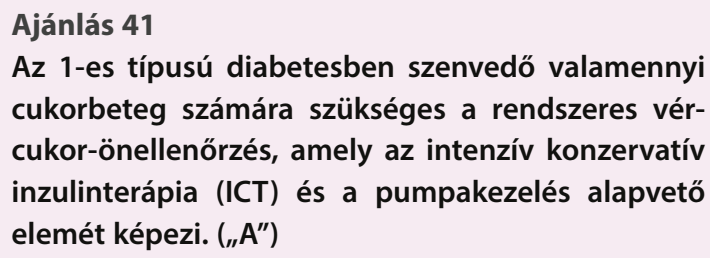

A DCCT volt az első tanulmány, amely felhívta a figyelmet arra, hogy 1-es típusú cukorbetegségben szenvedők körében az intenzív konzerva- tív inzulinterápia (ICT) vagy a pumpakezelés (vs. konvencionális inzulinkezelés) számottevően jobb anyagcserehelyzetet biztosít, hozzájárulva az idült szövődmények kialakulásának megakadályozásához, ill. progressziójuk lassításához. ${ }^{75}$ A kezelésnek szerves részét képezte a szisztematikusan kivitelezett vércukor-önellenőrzés és a talált értékek alapján történt inzulindózis-adaptálás. Az eredmények megismerése (1993) óta minden 1-es típusú cukorbeteg számára egyértelműen ajánlott a vércukor-önellenőrzés, amely megteremtette a betegek számára az önmenedzselés lehetőségét is.

\section{Ajánlás 42}

A 2-es típusú diabetesben szenvedő, inzulinnal kezelt cukorbetegek számára ajánlott a rendszeres vércukor-önellenőrzés. („B”)

A 2-es típusú diabetesben alkalmazandó vércukor-önellenőrzés klinikai hasznosságát több vizsgálat, köztük Cochrane-adatok elemzése során tanulmányozták. ${ }^{197,198,199} \mathrm{Az}$ irodalomban az ilyen vizsgálatokban elkülönítve analizálják az inzulinnal kezelt és nem kezelt 2-es típusú cukorbetegeket. Egyértelmü, hogy az inzulinnal kezelt 2-es típusú cukorbetegek profitálnak a vércukor-önellenőrzésből, mert jobb anyagcserehelyzet és a késői szövődmények visszaszorítása érhető el a rendszeres vércukor-önellenőrzést végző (vs. nem végző), inzulinnal kezelt 2-es típusú cukorbetegek körében. ${ }^{200,201}$

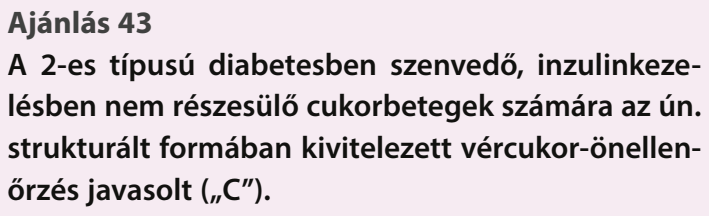

$\mathrm{Az}$ inzulinkezelésben nem részesülő 2-es típusú cukorbetegek körében végzett vércukor-önellenőrzés klinikai hasznosságáról az irodalmi állásfoglalás kevésbé egyöntetű. ${ }^{35,36}$ Találhatók a vércukor-önellenőrzés hasznosságát támogató és azt kétségbe vonó tanulmányok is, a támogató tanulmányok $^{202,203,204,205}$ többségben vannak. Ugyanakkor egyértelmủ az állásfoglalás a tekintetben, hogy a vércukor-önellenőrzés hasznossága (anyagcserekontroll javulása és/vagy a hypoglykaemia-kockázat csökkenése) csak a strukturált betegoktatás keretén belül valósulhat meg. ${ }^{35} \mathrm{Ez}$ azt jelenti, 
hogy minden esetben meg kell találni azt a módot, amellyel a mért értékek jelentősége a betegek számára kommunikálható. Csak így remélhető, hogy a rendszeres vércukor-önellenőrzés nem a mért adatok gyüjtését, hanem azok hatékony felhasználását jelenti a jobb anyagcserehelyzet elérése, a hypoglykaemia elkerülése érdekében. Az irodalomban vitatott, hogy ebben a betegcsoportban a vércukor-önellenőrzés hozzájárul-e az idült szövődmények megelőzéséhez, vagy sem.

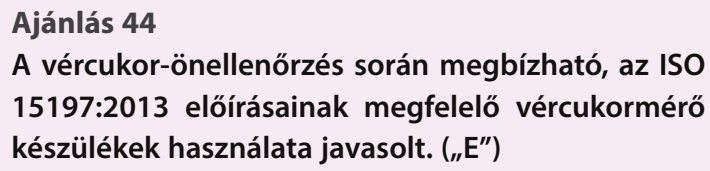

A vércukor-önellenőrzésre használt készülékek pontossága, megbízhatósága nagy jelentőségü. A legújabb, 2013-ben publikált ISO kritériumok szigorodtak a korábbi, 2003-ban kelt változathoz képest. ${ }^{206,207}$ Ma a vércukormérő készülékek pontosságának megállapításához az ISO 15197:2013 kritériumait kell használni. A kérdést azért kell komolyan venni, mert több országban elterjedőben vannak olyan készülékek, amelyeknek eredete bizonytalan, pontossága kétséges, ezek használata nyilvánvalóan nem preferálható. A szakirodalomban 2010-2014 között legalább 6 tanulmány foglalkozott az elérhető vércukormérő készülékek pontosságával, de a vizsgált készülékeknek csupán 14-67\%-a felelt meg az ISO 15197:2013 előírásainak. ${ }^{36} \mathrm{~A}$ legújabb, hazánkban forgalmazott vércukormérők pontosságát már az ISO 15197:2013 kritériumai szerint állapítják meg. ${ }^{208}$

Itt jegyezzük meg, hogy noha a vércukor-önellenőrzésre használt vércukormérő-készülékek mérési megbízhatósága napjainkban sokkal jobb, mint egy-két évtizeddel ezelőtt, a jelenleg érvényes szakmai állásfoglalás szerint a glukométer mérési eredménye a cukorbetegség kórismézésére nem alkalmas, e célra a glukométerek használata nem ajánlott.

\subsection{Folyamatos szövetiglukóz-monitorozási rendszer (CGMS: continuous glucose monitoring system)}

A folyamatos szövetiglukóz-monitorozási rendszer (CGMS: continuous glucose monitoring sys- tem) információt szolgáltat a vércukorváltozások irányáról, amplitúdójáról, időtartamáról, frekvenciájáról és a fluktuáció okairól is. Ezen rendszerek segítenek a betegnek abban, hogy megismerje a diéta, a mozgás, egyéb betegségek, a stressz, a gyógyszerek vércukorszintre kifejtett hatását. Az adatok segítenek abban is, hogy a beteg felismerje a hypo- és hyperglykaemiás epizódokat, megteremtve a megelőzés és a kezelés lehetőségét. A glukózmonitorozásra alkalmas első, engedélyezett eszköz a Minimed által kifejlesztett CGMS volt, melyet 1999-ben engedélyeztek az Egyesült Államokban.

A glukózoxidáz-alapú szenzor az extracelluláris folyadék glukóztartalmát méri. A kapilláris glukózmeghatározással, a kalibrálással együtt a CGMS által mért értékek megfelelően tükrözik a vércukorszintet. A szenzor glukózoxidáz-alapú platinaelektróda. A glukózoxidáz katalizálja a glukóz oxidációját az interstitialis folyadékban és ez elektromos áramot generál. Ezt az elektromos változást (áramot) kábel vezette az első monitorokba, amelyek 10 másodpercenként analizálták az adatokat, és az átlagértékek alapján ötpercenként megadták a glukózkoncentrációt. Ez napi 288 mérést jelentett, ezek megfelelő pontosságát a beteg glukométer által mért kapilláris vércukorszinttel történő napi négy kalibrálása biztosította. Az első eszközöket 72 óráig lehetett használni. A mai szenzorok már minimálisan 168 órás időtartamig alkalmasak mérésre. Az eszközök, a szenzorok mérete jelentősen csökkent, a szenzorok pontossága lényegesen javult. A használat során minimális számban fordul elő enyhe szövődmény (fertőzés a beszúrás helyén, vérzés, kontakt dermatitis). ${ }^{75,209}$

$\mathrm{Az}$ első rendszerek nem adtak lehetőséget arra, hogy a CGMS által aktuálisan mért értéket megtekintse a beteg. A Guardian volt az első, engedélyezett, megfelelő pontosságú, az aktuális vércukorértéket tükröző „real-time” monitor-rendszer (RT-CGMS). A Guardian alkotóelemei: a szenzor, a rádiófrekvenciás transzmitter és a monitor. Az interstitialis folyadék glukóztartalmát mérő eszköz transzmittere rádiófrekvenciás jelként továbbítja az információkat a monitorhoz, amely ötpercenként ad meg glukózértéket (24 óra alatt 288 mérés történik). Az eszköz kényelmesebb a beteg számára, mert 
nem köti össze kábel a szenzort a monitorral. A Guardian már lehetőséget nyújt arra, hogy a beteg azonnal láthassa a monitor által mért értéket. A riasztófunkció lehetővé teszi a beteg által nem észlelt, meg nem érzett hypoglykaemia felismerését, kezelését és a hyperglykaemia észlelését. Igaz ugyanakkor, hogy a készülék nem a vércukorértéket méri, hanem az interstitialis folyadék azt tükröző glukózkoncentrációját - azaz késlekedéssel, eltolódással jelzi a glykaemiás állapotban bekövetkező változásokat. Ez a fiziológiás - 10-20 perces - eltolódás („,lag fázis”) minden ilyen jellegü rendszert jellemzi. A rendszer alapkövetelménye a megfelelő betegoktatás, a beteg általi kalibrálás, amely a kapilláris glukózérték meghatározásával történik. A hyperglykaemia miatti bolus inzulin beadását, a hypoglykaemia miatti szénhidrátbevitelt nem a szenzor adatai, hanem a kapilláris vércukorértékek ismeretében szükséges elvégezni. A CGMS és RTCGMS nemcsak diagnosztikus, hanem edukációs eszköz is lehet. A rendszerek különösen alkalmasak a korábban ki nem mutatott, meg nem érzett hypoglykaemiák detektálására és a későbbiekben ezek megelőzésére. ${ }^{75,209}$

Egyes pumpák szenzor felhelyezése esetén már képesek a hypoglykaemia-tendenciák felismerésére, ekkor az inzulinadagolás felfüggesztésére, így a hypoglykaemiák száma csökkenthető. 2011től elérhető az ún. iPRO CGMS, amelyet „professzionálisnak" is neveznek. Ez a rendszer elsősorban diagnosztikus jellegű, a beteg nem látja az eszköz által mért értékeket, nem korrigál feleslegesen.

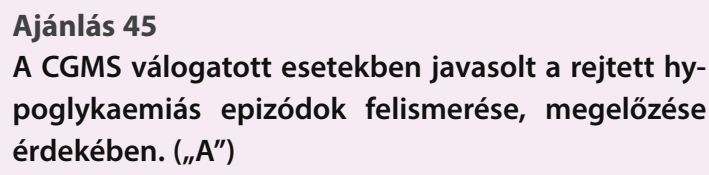

A Continuous Glucose Study Group Trial volt az első vizsgálat, amely bizonyította 1-es típusú cukorbetegnél a CGMS előnyeit. Azóta számos vizsgálat kellő evidenciával alátámasztotta a CGMS használatát. ${ }^{210,211,212}$

Hypoglykaemia-érzet hiánya és/vagy gyakori hypoglykaemiás periódusok esetében a vércukor-önellenőrzés mellett a CGMS segít a hypoglykaemiás epizódok azonosításában, megszüntetésében
(„A”). A CGMS használata javasolt a 25 évesnél idősebb, 1-es típusú cukorbetegek ICT kezelése során, a módszer hozzájárul a $\mathrm{HbA}_{1 \mathrm{c}}$-értékek csökkentéséhez („A”). Fiatalabb betegeknél (gyermekeknél, tinédzsereknél, fiatal felnőtteknél) ez az összefüggés nem ilyen erős, a siker mértéke korrelál az eszköz folyamatos használatával, az adherenciával. Ebben a betegcsoportban kevesebb evidencia áll rendelkezésre a $\mathrm{HbA}_{1 c}$ csökkentésére vonatkozóan („B”). Amennyiben a betegek már sikeresen használták a CGMS-t, akkor az eszköz további használata javasolható 65 éves kor felett is („E”).

A betegek túlnyomó többségének ma is a glukométerekkel történő vércukor-önellenőrzés a realitás. A legtöbb betegnél elégséges is ez a módszer, de a CGMS számos betegnél javíthatja az eredményeket, segít a másképp fel nem ismert hypoglykaemiák detektálásában és megelőzésében. A CGMS használata előtt részletes oktatás és gyakorlás szükséges. Az eredmények értékeléséhez a beteget az egészségügyi dolgozóknak folyamatosan edukálni, oktatni szükséges. Magyarországon a CGMS társadalombiztosítási támogatásban jelenleg nem részesül, ez is az oka annak, hogy hazánkban a módszer nem terjedt el eddig megfelelő mértékben.

\subsection{Gondozás, betegoktatás cukorbetegségben}

A 2-es típusú cukorbetegségben szenvedők gondozása a komplex háziorvosi ellátás keretében valósulhat meg a legeredményesebben, a szakorvosi ellátórendszernek konzultáció céljából elérhetőnek kell lennie. Helyes, ha inzulinkezelésben részesülő, ill. szövődménnyel terhelt 2-es típusú cukorbetegek, valamint az 1-es típusú cukorbetegek, ill. a terhes diabetikák diabetes-szakambulancián állnak gondozás alatt, szorosan együttműködve a háziorvossal.

A cukorbetegségben szenvedő felnőtt egyének ellátásával kapcsolatos háziorvosi feladatokat és kompetenciákat összefoglaló közlemény (A háziorvos feladatai és kompetenciái a diabetes mellitus kórismézéséről, a cukorbetegek antihyperglykaemiás kezeléséről és gondozásáról felnőttkorban - összeállította Dr. Oláh Ilona) a Diabetologia Hungarica 2017. évi 1. szám része- 
ként, a jelenlegi szakmai irányelvhez csatlakozóan jelenik meg.

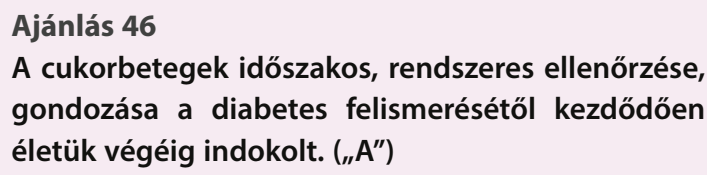

A sok időt és egyéni törődést igénylő feladat feltételezi a jól képzett, önállóan (is) dolgozó diabetológiai szakápoló, ill. dietetikus jelenlétét a szakgondozást végző munkacsoportban, ${ }^{213,214}$ ezt egyébként a hazai minimumfeltétel-rendszer rendelete elő is írja.

A cukorbeteg-gondozás célja:

- az akut tünetek megszüntetése;

- a glykaemiás kontroll javítása;

- a beteg önmenedzselési képességének segítése;

- a jó életminőség tartós biztosítása;

- a szövődmények kialakulásának megelőzése;

- a fennálló szövődmények kezelése.

A cukorbeteg-gondozás keretében megvalósítandó feladatok attól függnek, hogy a beteget első alkalommal látjuk-e, vagy ismételten jelenik meg a szakrendelésen.

A diabetes felismerésekor, illetve a beteg első megjelenésekor tisztázandó körülmények, ill. elvégzendő feladatok:

- anamnézis (családi is, nőknél szülészeti események), táplálkozási és életmódi szokások, foglalkozás, fizikai aktivitás, iskolai végzettség, korábbi gyógyszeres kezelés tisztázása;

- teljes körű fizikális vizsgálat: testsúly, testmagasság, haskörfogat, vérnyomás mérése, a láb vizsgálata (talp, deformitások, gombásodás, perifériás artériák tapintása, neuropathia ellenőrzése hangvillával), EKG készítése, BMI meghatározása;

- szemfenék (gyakorlott szemész általi) vizsgálata, tágított pupillák mellett;

- laboratóriumi vizsgálatok: $\mathrm{HbA}_{1 c}$; vércukor éhomra és postprandialisan, szérum össz-koleszterin, HDL-koleszterin, LDL-koleszterin (mérve vagy becsülve), triglicerid, kreatinin, eGFR, vizeletcukor és -aceton, üledék, szükség esetén vizelettenyésztés, kvantitatív albuminürítés (microalbuminuria)

- a betegoktatás megkezdése;
- dietetikai tanácsadás;

- az orális antidiabetikumok alkalmazásának elmagyarázása (ha aktuális);

- az inzulinterápia beállítása (ha szükséges), az ehhez szükséges injekciózási technika megtanítása;

- vércukor-önellenőrzés jelentőségének elmagyarázása (ha aktuális: megtanítása);

- dohányzással kapcsolatos tanácsadás;

- a rendszeres fogorvosi ellenőrzés fontosságának hangsúlyozása.

A beteg ellenőrzésének (gondozásának) gyakoriságát a betegség típusa, a kezelés módja, valamint az esetleges szövődmények jelenléte határozza meg. 1-es típusú betegek esetében általában évi 4-6, 2-es típusú (nem inzulinnal kezelt) beteg gondozása során évi 2-4 alkalommal javasolt az ellenőrzés.

Minden orvos-beteg találkozáskor elvégzendő:

- az oktatás folytatása,

- testsúly és haskörfogat mérése, BMI meghatározása,

- vérnyomásmérés,

- éhomi és postprandialis vércukormérés, önellenőrzést végző betegnél a kezelési napló alapján az anyagcsere-vezetés megbeszélése,

- terápiahűség értékelése, erősítése.

Évente legalább egy alkalommal elvégzendő:

- teljes körű vizsgálat (mint első alkalommal), különös tekintettel a láb vizsgálatára,

- a szemfenék ellenőrzése,

- teljes körű laboratóriumi vizsgálat (mint első alkalommal),

- a kezelés áttekintése,

- az önellenőrzési technika ellenőrzése,

- az étrendi és táplálkozási ismeretek áttekintése.

A $\mathrm{HbA}_{1 c}$ vizsgálata (laboratóriumi méréssel) évi 3-4 alkalommal javasolt, a kezelési célértéket egyénileg kell a beteg számára meghatározni. A szérum lipidek vizsgálata általában évente egy alkalommal szükséges. Kóros vérzsírszintű és/vagy antilipaemiás kezelésben részesülő egyének esetében ennél gyakoribb vizsgálat indokolt. A vérkép vizsgálata évente 2-3 alkalommal indokolt.

\section{Ajánlás 47}

Minden cukorbeteget a diabetes felismerésétől kezdve rendszeres és strukturált edukációban kell részesíteni. („B”) 
A páciensedukáció a cukorbeteg-gondozás nélkülözhetetlen eleme. A diabetes önmenedzselését segítő edukáció (diabetes self-management education - DSME) és támogatás (diabetes self-management support - DSMS) hatékonyságát a diabetesszel kapcsolatos készségek javulását, a szénhidrát-anyagcsere paramétereinek változását a gondozási folyamat részeként kell értékelni. ${ }^{4,215,216,217} \mathrm{Az}$ edukáció betegcentrikus legyen, figyelembe kell venni a páciens igényeit, szocio-kulturális helyzetet, iskolázottságát. Mivel az edukáció az anyagcserehelyzet javulását eredményezi, hosszabb távon a szövődmények kialakulásának kockázatát csökkenti, indokolt, hogy e tevékenységet a betegellátást finanszírozó intézmény (biztosító) a támogatott tevékenységi körbe bevonja.

\subsection{A diabetes megelőzésének lehetőségei}

A két alapvető diabetes-típus megelőzési lehetőségei élesen eltérnek egymástól.

\section{Az 1-es típusú diabetes megelőzése}

Noha a családi anamnézisben szereplő 1-es típusú diabetes, az autoantitest (ICA, GADA, IA-2) pozitivitása és az intravénás glukózra bekövetkező első, gyors fázisú inzulinválasz kiesése előrejelzik az 1-es típusú diabetes kialakulását, jelenleg az orvostudomány nem ismer olyan megelőzési módszert, amely hatékonyan, biztonságosan és mellékhatástól mentesen biztosítaná az 1-es típusú diabetes megelőzését. Napjainkban - bár ismereteink egyre bővülnek - az 1-es típusú diabetes megelőzése nem megoldott, azaz a klinikai gyakorlatban az 1-es típusú diabetes prevenciója jelenleg nem tekinthető realitásnak. ${ }^{218,219}$

\section{A 2-es típusú diabetes megelőzése}

A 2-es típusú diabetest ma a szakirodalom megelőzhető betegségnek tartja. ${ }^{20,221}$ A megelőzésének leghatékonyabb eszköze az életmód-terápia: megfelelő táplálkozással a kívánatos testsúly elérése és/vagy megtartása, valamint a rendszeres fizikai aktivitás. ${ }^{222}$ A prevenciós tevékenység a cukorbetegség kialakulása vonatkozásában nagy koc- kázattal rendelkező személyek felkutatására, szűrésére és adott esetben kezelésére irányul. A 2-es típusú diabetes és kórmegelőző állapotai vonatkozásában fokozott kockázatot jelentő állapotokat a 21. táblázat összegzi.

\section{Ajánlás 48}

A 2-es típusú diabetes és kórmegelőző állapotai felkutatása céljából kockázatalapú szűrés javasolt. $\left(\right.$, $\left.A^{\prime \prime}\right)$

A kockázatalapú szűrés azt jelenti, hogy első lépcsőben egy egyszerű kérdőívvel azonosítjuk a fokozott kockázatú egyéneket és laboratóriumi vércukor-meghatározást csak a fokozott kockázatúak körében végzünk. Költséghatékonysága, egyszerűsége és nemzetközileg validált jellege miatt első lépésként a FINDRISC kérdőív (szabadon letölthető: www.diabet.hu) használata ajánlott, amely jól használható a háziorvosi gyakorlatban, az alapellátás szintjén is. ${ }^{37}$ A FINDRISC kérdőiv alapján nagy kockázattal rendelkező személyek (összpontszám >12) esetében 75 g glukózzal előírás szerinti OGTT végzendő. ${ }^{15}$ Kardiovaszkuláris betegség gyanúja esetén a szív- és érrendszer állapota a szükséges vizsgálatok elvégzésével tisztázandó. A testtömeg-index meghatározása mellett a haskörfogat mérése, a vérnyomás, a lipidértékek ellenőrzésével együtt fontos a dohányzás, táplálkozási szokások és életmódi tényezők regisztrálása is.

\section{1. táblázat. A diabetes/prediabetes vonatkozásá- ban fokozott kockázatot jelentő állapotok}

\footnotetext{
- Súlytöbblet/elhízás (túlsúly: BMI 25,0-29,9 kg/m², elhízás: BMI $\geq 30 \mathrm{~kg} / \mathrm{m}^{2}$; a centrális obesitas könnyen mérhető a haskörfogat meghatározásával - az európai népességben férfiaknál $\geq 94 \mathrm{~cm}$, nőknél $\geq 80 \mathrm{~cm}$ minősül kórosnak)

- Pozitív családi kórelőzmény (cukorbetegség előfordulása a közeli vagy távolabbi rokonok között)

- Életkor ( $\geq 45$ év az európai népességben nagyobb kockázatot jelent)

- Hypertonia vagy szív- és érrendszeri betegség a

kórelőzményben

- Mozgásszegény életmód

- Gesztációs diabetes vagy $4000 \mathrm{~g}$ feletti magzat szülése a

kórelőzményben

- Bizonyos gyógyszerek (glucocorticoidok, tiazid-típusú diuretikumok, antipszichotikumok, interferon-alfa stb.) szedése
} 
A diabetes-szűrés gyakorisága a mindenkor hatályos vonatkozó jogszabályhoz igazodik.

A gesztációs diabetesben szenvedők szülés utáni időszakos ellenőrzése, diabetes-szűrése indokolt, a részletek a 3.6. fejezetben lelhetők fel.

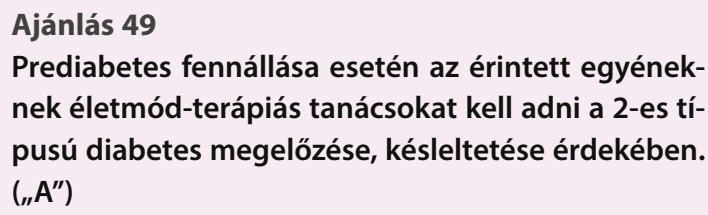

Kellően kivitelezett, randomizált, kontrollált klinikai tanulmányok különböző népcsoportokban (Kína, Finnország, Egyesült Államok) igazolták, hogy életmód-terápiával (diétával és fokozott fizikai aktivitással) IGT-s, testsúlyfelesleggel rendelkező egyének körében a 2-es típusú diabetes kialakulása számottevően visszaszorítható. $223,224,225 \mathrm{Az}$ intervenció (életmód-terápia) előnye hosszú időn keresztül, a randomizált tanulmány zárása utáni periódusban is észlelhető. $226,227,228$

\begin{abstract}
Ajánlás 50
Életmód-terápia mellett a metformin adása megfontolandó prediabetesben a 2-es típusú diabetes visszaszorítása érdekében. („E”)
\end{abstract}

$\mathrm{Az}$ irodalomban számos gyógyszerrel folyt prevenciós tanulmány. IGT stádiumában lévő testsúlyfelesleggel rendelkező egyének esetében a 2-es típusú diabetes kialakulásának kockázata visszaszoríthatónak bizonyult akarbóz, ${ }^{229}$ valsar$\tan { }^{230}$ orlistat $^{231}$ adásával, gesztációs diabetesben szenvedők körében a pioglitazon bizonyult hatékonynak. ${ }^{232}$ IFG vagy IGT stádiumában lévő egyének esetében glargin adásával csökkenthető volt a 2-es típusú diabetes kialakulása. ${ }^{154}$ Hazánkban - az alkalmazási elöírás alapján - egyedül a metformin adható prediabetesben. Adása megfontolandó (életmód-terápia mellett) elsősorban akkor, ha a BMI $>35,0 \mathrm{~kg} / \mathrm{m}^{2}$, ha a kor $<60$ év, és nőknél, ha az anamnézisben GDM szerepel. A várható eredményességet (a 2-es típusú diabetes kialakulásának kockázatcsökkenését) nagy klinikai tanulmány igazolta. ${ }^{225}$

\section{Javaslatok az ajánlások alkalmazásához}

\section{Az alkalmazás feltételei a hazai gyakorlatban}

A cukorbeteg-ellátás, a cukorbeteg-gondozás a háziorvosi tevékenység egyik alapeleme. Konzultációt igénylő esetekben a háziorvos munkáját a diabetológiai szakellátó-rendszer segíti. A cukorbetegek ellátásában speciális helyzetben (pl. diabetes és terhesség), ill. szövődmények (szemészeti, renalis, angiológiai, kardiológiai, neurológiai szövődmények) esetén a társszakmák képviselői szerepet kapnak.

A 2-es típusú diabetes megelőzhető betegség. A prevenció megvalósítása csak társadalmi összefogással valósulhat meg, önmagában az egészségügy szereplői ezzel a feladattal nem tudnak megbirkózni a siker reményében.

Az MDT 2011-ben kidolgozta és megjelentette a Nemzeti Diabetesprogramot, ${ }^{233}$ azt a hatóság képviselőinek bemutatta. A Nemzeti Diabetes- program javaslatot tett az ellátás korszerűsítésére, a megelőzés gyakorlati kivitelezésére. A hatóság a Nemzeti Diabetesprogrammal egyetértett, de anyagi erőforrást nem állt módjában mellé rendelni. A program sorsát ez az alapvető körülmény meghatározta.

A Nemzeti Diabetesprogram 2011 célkitűzései az alábbiak voltak:

- a nagyfokú kockázattal rendelkező egyének felismerése, s körükben a diabetes és a kardiovaszkuláris kockázat csökkentésének elérése;

- a diabetes és kockázati tényezőinek tudatosítása a lakosság körében;

- a megfelelő terápia időben történő biztosítása a szűrés során diabetesesnek bizonyult betegek számára;

- a cukorbeteg-gondozás szakmai és szervezeti színvonalának fejlesztése;

- a cukorbetegséggel kapcsolatos kutatás támogatása. 
A cukorbeteg-gondozás szakmai és szervezeti színvonalának fejlesztése terén az alábbi célokat tűzték ki:

- a diabetológiai minősítés jogi helyzetének rendezése - megoldódott a diabetológiai licencvizsga bevezetésével;

- a cukorbeteg-ellátás finanszírozásának felülvizsgálata - permanens gond, hogy a cukorbeteg-gondozás során elszámolható tevékenységek alacsony finanszírozásban részesülnek, ennek következtében önállóan működő diabetológiai szakellátó helyek csak veszteségesek lehetnek (s ezért bezárnak), a kórházi osztályok mellett működő ambulanciák veszteségét az osztályok működése kompenzálja, de az áldatlan helyzet napi nézeteltérés forrása a legtöbb intézetben;

- a diabetológiai szakápoló-képzés folytonosságának biztosítása - az MDT ezt továbbra is végzi, szép sikerrel;

- a podiáter-képzés elindítása - 2015-ben Miskolcon elindult az első évfolyam;

- a diabetes szakellátó-rendszer további építése - háziorvosi szinten feltehetően a csoportpraxis kiépítése jelenthet megoldást;

- dietetikusok diabetológiai továbbképzése - az MDT több tanfolyamot szervezett;

- diabetológiai szakápolók folyamatos továbbképzése - az MDT ebben szerepet vállalt több továbbképzés keretén belül;

- a páciensedukáció szervezeti körülményeinek és finanszírozási feltételeinek felülvizsgálata - az egyik legsúlyosabb gond, hogy a páciensedukáció (ami a betegség felismerésekor alapvető jelentőségü, szerepe azonban az életre szóló betegség lefolyásának egyes periódusaiban ismételten komoly hangsúlyokat kap) nem részesül finanszírozásban (ami példátlan Európa más országaihoz viszonyítva) - az egészségügyi szakápolók, orvosok ezen a téren kifejtett tevékenysége nem alapulhat önkéntes lelkesedésen;

- a gesztációs diabetes szűrésének teljes körűvé tétele, a diabeteses terhesek felkészült centrumban történő ellátásának biztosítása - ez gyakorlatilag megvalósult;

- az idült szövődmények szűrését biztosító diagnosztikai eszköztár bővítése (nonmidriatikus fundusfotó telemetrikus értékelése) - szemész kollégákkal együttműködve elindult hazánkban;

- minőségbiztosítás meghonosítása - háziorvosi praxisokban a hatóság bevezette, de a módszernek számos hátulütője van;

- a cukorbetegek esélyegyenlőségi elvének folyamatosan hangsúlyozása - ezt hirdetjük, de miután hirdetni kell, nyilvánvaló, hogy nem valósul meg teljes körủen;

- az MDT központi oktató, továbbképző és betegellátó centrumának létrehozása - ez még várat magára.

\subsection{Ellátók kompetenciája (pl. licence, akkreditáció stb.), kapacitása}

A cukorbeteg-ellátás helyzete 2016-ban Magyarországon

A 2-es típusú diabetes mellitus gondozása alapesetben a háziorvos önálló betegellátási feladatkörébe tartozik, szakorvosi javaslatot igénylő terápiaváltás szükségessége esetén konzílium keretében kéri meg a javaslatot. A háziorvosok munkáját alapvetően nehezíti, hogy erős leterheléssel dolgoznak, a betegre fordított rendelési idő minimális, általánosságban csak egy kisegítő egészségügyi dolgozót tudnak foglalkoztatni. Így az újonnan felismert 2-es típusú diabetesben oly fontos dietetikai ismeretek átadására megfelelő módon alig szokott sor kerülni. Az antidiabetikumok egyre bővülő tárházából mindössze metformin és szulfanilurea felírását kezdeményezhetik, a korszerűbb készítmények inicializálásához szakorvosi javaslatot kell kérniük a szakellátó hálózattól.

Helyes, ha az 1-es típusú diabetesben szenvedők gondozását alapvetően a szakellátó hálózat végzi, a háziorvosokkal együttműködve. Indokolt, hogy előrehaladott szövődményben szenvedő betegek kezelése-gondozása terén a specialisták (nefrológusok előrehaladott veseszövődmény, angiológusok érszövődmény, kardiológusok akut kardiológiai események, szemészek előrehaladott szemészeti szövődmények esetén) érdemben bekapcsolódjanak a cukorbeteg-ellátásba. Ebben a stádiumban a diabetológiai gondozás helyesen már a szakellátó helyeken történik. A terhes diabetikák diabetológiai gondozása ezzel a feladattal foglalkozó szakellátó helyeken történhet csak. 


\subsection{Speciális tárgyi feltételek, szervezési kérdések (gátló és elősegítő tényezők, és azok megoldása)}

\section{A diabetológiai szakellátó helyek rendszere 2016-ban Magyarországon}

Az előzményekhez tartozik, hogy az MDT saját kezdeményezés nyomán 1996-ban létrehozta a diabetológiai minősítést, és nyilvántartásba kezdte venni (akkreditálta) a diabetológiai szakellátó helyeket. Közel 500 kolléga (döntő többségben belgyógyászok, kisebb hányadban gyermekgyógyászok és más társszakmák képviselői) szereztek minősítést. A nyilvántartott diabetológiai szakellátó-helyek száma országosan 200-210 közötti volt.

Jelentős változás következett be 2014-ben, amikor a hatóság megteremtette a diabetológiai licenc törvényi feltételeit. A korábban diabetológiai minősítést szerzettek szinte kivétel nélkül (mintegy 500 fő) megszerezték a diabetológiai licencet (ezzel egy időben az MDT diabetológus minősítési képzése, vizsgáztatása megszűnt).

A diabetológiai szakellátó helyek minimumfeltételét a hatóság rendeletben írta elő mintegy 4-5 évvel ezelőtt. A szakellátó helyek nyilvántartását, akkreditálását az MDT továbbra is végzi.

A jövőben a diabetológiai licenchez kötött tevékenységek meghatározása az egyik szakmai feladat.

\subsection{Az ellátottak egészségügyi tájékozottsága, szociális és kulturális körülményei, egyéni elvárásai}

A cukorbetegség sikeres vagy kevésbé eredményes ellátása nagyban függ az érintett betegek életkorától, iskolai végzettségétől, szociális körülményeitől. Önmagában az életmód-terápiának (diéta, rendszeres mozgás, sportolás, fizikai aktivitás) is van anyagi vetülete, a kezelésben használatos gyógyszerek árai (támogatottság mellett is) néha gondot jelentenek az érintett betegek számára. Az egyénre szabott kezelés elvének megfelelően ezeket a körülményeket mindig mérlegre kell tenni.

\subsection{Egyéb feltételek}

Nincs.

\section{Alkalmazást segítő dokumentumok listája}

L. a XI. Mellékletet!

\section{A gyakorlati alkalmazás mutatói, auditkritériumok}

Diabetesben a végkimeneteli mutatók a diabetes mikro- és makrovaszkuláris szövődményeinek végállapotát jelentik (végstádiumú veseelégtelenség, vakság, alsó végtagi amputáció, szívinfarctus, stroke). Miután kialakulásuk általában többéves folyamat következménye, elemzésük csak hosszú távon célszerü.

A köztes kimeneteli mutatók a diabetes-specifikus végállapotokat megelőző patológiás elváltozásokat jelentik, ezek közé tartoznak a szemen észlelhető eltérések (retinopathia súlyossági foka), a lábon megjelenő elváltozások (pl. talpi fekély), ill. kóros neurológiai vizsgálati leletek, a micro- vagy macroalbuminuria és a szérum kreatininérték. Köztes kimeneteli mutatóként értékelik az anyagcserekontroll fokát ( $\mathrm{HbA}_{1 \mathrm{c}}$-érték), a hypoglykaemia és ketoacidosis előfordulási gyakoriságát, ill. a makrovaszkuláris kockázati tényezők (szérum lipidek, vérnyomás, testtömeg-index, haskörfogat, carotis-falvastagság) alakulását.

Az előzőekben említett vég- és köztes kimeneteli mutatók nem alkalmazhatók az ellátás minőségi indikátoraikként, miután azok alakulásában az egészségügyi ellátás minősége csak egy a sok tényező közül, s a kimenetelre több olyan körülmény is hat, amelynek befolyásolására az egészségügy szereplőinek nincs hatása. Az ellátás minőségi indikátoraként ezért csak azok a tevékenységek vehetők számba, amelyek elvégzése vagy mellőzése kihat a vég- és köztes kimeneteli mutatók alakulására.

Az alábbi indikátorok használata jön szóba:

- $\mathrm{HbA}_{1 \mathrm{c}}$-meghatározás évenkénti száma (kívánalom inzulinnal kezeltek körében évente 4, inzulinnal nem kezeltek körében évente 2 mérés);

- inzulinnal kezeltek körében a vércukor-önellenőrzést végzők aránya (kívánalom: 90\%);

- teljes körű laboratóriumi ellenőrzés (beleértve az eGFR és a microalbuminuria meghatározását is) évente egyszer (kívánalom: 100\%); 
- szemfenék-vizsgálat évente egyszer (kívánalom: $90 \%$ );

- neuropathia-vizsgálat (hangvilla) a láb megtekintése évente egyszer (kívánalom: $100 \%)$
- EKG-vizsgálat évente egyszer (kívánalom: $90 \%)$

- fizikális vizsgálat (antropometriai paraméterek), vérnyomásmérés évente egyszer (kívánalom: $100 \%$ ).

\section{Irányelv felülvizsgálatának terve}

A z egészségügyi

szakmai

irányelvvel kapcsolatos aktuális szakirodakövetéséért, a változások azonosításáért és az aktualizálás elvégzéséért (ha szükséges) a Belgyógyászat, Endokrinológia, Diabetes és Anyagcserebetegségek Szakmai Kollégium tagozata/tanácsa felel.

\section{Irodalom}

1. WHO: Definition, diagnosis and classification of diabetes mellitus and its complications. Report of a WHO consultation. Part 1: Diagnosis and classification of diabetes mellitus. Geneva, 1999. Magyar nyelvű szöveghű fordítása: Diabetologia Hungarica 2000; 8(Suppl 2): 1-29.

2. World Health Organization: Definition and diagnosis of diabetes mellitus and intermediate hyperglycaemia. Report of a WHO consultation. WHO, Geneva, 2006.

3. Inzucchi SE, Bergenstal RM, Buse JB, Diamant M, Ferrannini E, Nauck M, et al.: Management of hyperglycaemia in type 2 diabetes: a patient-centered approach. Position statement of the American Diabetes Association (ADA) and the European Association for the Study of Diabetes (EASD). Diabetes Care 2012; 35: 1364-1379. doi:10.2337/dc12-0413

4. Inzucchi SE, Bergenstal RM, Buse JB, Diamant M, Ferrannini E, Nauck M, et al.: Management of hyperglycemia in type 2 diabetes, 2015: A patientcentered approach: Update to a position statement of the American Diabetes Association and the European Association for the Study of Diabetes. Diabetes Care 2015; 38: 140-149. doi:10.2337/dc14-2441
Tervezett felülvizsgálat: a szakmai irányelv érvényességének lejártakor.

Soron kívüli felülvizsgálat: a szakmai irányelv érvényességén belül bármikor, ha a szakmai irodalomban vagy az ellátói környezetben olyan mértékű változás következne be, amely indokolná azt, hogy a felülvizsgálatra a tervezett felülvizsgálat időpontjánál korábban kerüljön sor.

5. American Diabetes Association: Standards of medical care in diabetes - 2016. Diabetes Care 2016; 39(Suppl 1): S1-S112.

6. Decsi T: A bizonyítékokon alapuló orvoslás (egyetemi tankönyv). Medicina Kiadó, Budapest, 2011.

7. Jermendy Gy: Evidence-based medicine: az első tizenöt év tapasztalatai. LAM 2007; 17: 154-159.

8. Jermendy Gy: Tényeken alapuló orvostudomány: fény- és árnyoldalak a diabetológiában. Diabetologia Hungarica 2013; 21: 135-144.

9. International Diabetes Federation: IDF Diabetes, 7th ed. Brussels, Belgium: International Diabetes Federation, 2015. http://www.diabetesatlas.org Letöltés: 2016. szept. 1.

10. International Diabetes Federation: IDF Diabetes, 5th ed. Brussels, Belgium: International Diabetes Federation, 2011. www.IDF.org/Diabetes Atlas 5th ed.

11. Jermendy G, Nádas J, Szigethy E, Széles G, Nagy A, Hídvégi T, et al.: Prevalence rate of diabetes mellitus and impaired fasting glycemia in Hungary - crosssectional study on nationally representative sample of people aged 20-69 years. Croat Med J 2010; 51: 151156. doi:10.3325/cmj.2010.51.151 
12. IDF Atlas 6 ed. 2014. www.idf.org/sites/default/files/DAregional-factsheets-2014_FINAL.pdf letöltés: 2016. júl 24.

13. Jermendy Gy, Kempler P, Abonyi-Tóth Zs, Rokszin Gy, Wittmann I.: A cukorbeteg-ellátás mutatóinak alakulása Magyarországon 2001-2014 között: az Országos Egészségügyi Pénztár adatbázis-elemzésének célja és módszertana. Orv Hetil 2016; 157: 1259-1265. doi:10.1556/650.2016.30519

14. Kempler P, Putz Zs, Kiss Z, Wittmann I, AbonyiTóth Zs, Rokszin Gy, Jermendy Gy: A 2-es típusú diabetes előfordulása és költségterheinek alakulása Magyarországon 2001-2014 között - az Országos Egészségbiztosítási Pénztár adatbázis-elemzésének eredményei. Diabetologia Hungarica 2016; 24: 177 188.

15. Winkler G, Hidvégi T, Vándorfi Gy, Balogh $\mathrm{S}$, Jermendy Gy: Kockázatalapú diabetesszűrés háziorvosi praxisokban, felnőtt egyének körében. Diabetologia Hungarica 2011; 19: 111-122.

16. NCD Risk Factor Collaboration (NCD-RisC): Worldwide trends in diabetes since 1980: a pooled analysis of 751 population-based studies with 4.4 million participants. Lancet 2016; 387: 1513-1530. doi:10.1016/S0140-6736(16)00618-8

17. Jansson SP, Fall K, Brus O, Magnuson A, Wändell P, Östgren CJ, et al.: O: Prevalence and incidence of diabetes mellitus: a nationwide population-based pharmaco-epidemiological study in Sweden. Diabet Med 2015; 32: 1319-1328. doi:10.1111/dme.12716

18. Józan P: Fordulat a halandóságban és azéletkilátásokban, epidemiológiai korszakváltás Magyarországon? Orv Hetil 2003; 144: 451-460.

19. Józan P: Rendszerváltozás és epidemiológiai korszakváltás Magyarországon. Orv Hetil 2012; 153: 662-677. doi:10.1556/OH.2012.29344

20. Alberti G, Zimmet P, Shaw J, Bloomgarden Z, Kaufman F, Silink M: Type 2 diabetes in the young: the evolving epidemic: the International Diabetes Federation consensus workshop. Diabetes Care 2004; 27: 1798-1811.

21. Körner A, Madácsy L: Rising tide of type 2 diabetes mellitus and impaired glucose tolerance among Hungarian children and adolescents. Diabetologia Hungarica 2002; 10(Suppl 2): 22-27.

22. Gyűrűs É, Soltész Gy: Az 1-es típusú diabetes mellitus incidenciája Európában, a EURODIAB adatai alapján. LAM 2004; 14: 399-404.
23. Gyürüs É, Patterson CC, Soltész Gy és a Magyar Gyermekdiabetes Epidemiológiai Munkacsoport: „Folyamatosan emelkedő vagy csúcsok és fennsíkok?” A gyermekkori 1-es típusú diabetes incidenciája Magyarországon. Orv Hetil 2011; 152: 1989-2009.

24. Gyűrűs EK, Patterson C, Soltész G; Hungarian Childhood Diabetes Epidemiology Group: Twentyone years of prospective incidence of childhood type 1 diabetes in Hungary - the rising trend continues (or peaks and highlands?). Pediatr Diabetes 2012; 13: 2125. doi:10.1111/j.1399-5448.2011.00826.x

25. Pánczél P, Külkey O, Luczay A, Bornemisza B, Illyés Gy, Halmos T, et al.: Hasnyálmirigy-szigetsejt elleni antitestek vizsgálata a klinikai gyakorlatban. Orv Hetil 1999; 140: 2695-2701.

26. Hosszúfalusi N, Vatay A, Rajczy K, Prohászka Z, Pozsonyi E, Horváth L, et al.: Similar genetic features and different islet cell autoantibody pattern of latent autoimmune diabetes in adults (LADA) compared with adult-onset type 1 diabetes with rapid progression. Diabetes Care 2003; 26: 452-457. doi:10.2337/diacare.26.2.452

27. A diabetes mellitus kórismézése, a cukorbetegek kezelése és gondozása felnőttkorban. A Magyar Diabetes Társaság szakmai irányelve, 2011 (szerk: Jermendy Gy, írta: Gaál Zs, Gerő L, Hidvégi T, Jermendy Gy, Kempler P, Winkler G). Diabetologia Hungarica 2011; 19(Suppl 1): 5-72.

28. A diabetes mellitus kórismézése, a cukorbetegek kezelése és gondozása felnőttkorban. A Magyar Diabetes Társaság szakmai irányelve, 2014 (szerk: Jermendy Gy, írta: Gaál Zs, Gerő L, Hidvégi T, Jermendy Gy, Kempler P, Winkler G, Wittmann I). Diabetologia Hungarica 2014; 22(Suppl 1): 2-84.

29. Az Egészségügyi Minisztérium szakmai irányelve a diabetes mellitus kórismézéséről, a cukorbetegek kezeléséről és gondozásáról a felnőttkorban. Készítette a Belgyógyászati Szakmai Kollégium és a Magyar Diabetes Társaság. Egészségügyi Közlöny LIX. ovf. 21. szám. 2935-2990. oldal. http://www.kozlonyok. hu/kozlonyok/Kozlonyok/6/PDF/2009/21.pdf Letöltés: 2016. aug. 24.

30. Garber AJ, Abrahamson MJ, Barzilay JI, Blonde L, Bloomgarden ZT, Bush MA, et al.: Consensus statement by the American Association of Clinical Endocrinologists and American College of Endocrinology on the comprehensive type 2 diabetes management algorithm - 2016 executive summary. Endocr Pract 2016; 22: 84113. doi:10.4158/EP151126.CS 
31. Canadian Diabetes Association Clinical Practice Guidelines Expert Committee, Harper W, Clement M, Goldenberg R, Hanna A, Main A, Retnakaran $\mathrm{R}$, et al: Pharmacologic management of type 2 diabetes. Can J Diabetes 2013; 37(Suppl 1): S61-S68. doi:10.1016/j.jcjd.2013.01.021

32. Canadian Diabetes Association Clinical Practice Guidelines Expert Committee, Harper W, Clement M, Goldenberg R, Hanna A, Main A, Retnakaran $\mathrm{R}$, et al.; Steering Committee for Canadian Diabetes Association 2013 Clinical Practice Guidelines for Prevention and Management of Diabetes in Canada: Policies, Guidelines and Consensus Statements: Pharmacologic Management of Type 2 Diabetes-2015 Interim Update. Can J Diabetes 2015; 39: 250-252.

33. Canadian Diabetes Association Clinical Practice Guidelines Expert Committee: Pharmacologic Management of Type 2 Diabetes: 2016 Interim Update. Can J Diabetes 2016; 40: 193-195. doi:10.1016/j.jcjd.2016.02.006

34. Rydén L, Grant PJ, Anker SD, Berne C, Cosentino F, Danchin N, et al.: ESC Guidelines on diabetes, prediabetes, and cardiovascular diseases developed in collaboration with the EASD: the Task Force on diabetes, pre-diabetes, and cardiovascular diseases of the European Society of Cardiology (ESC) and developed in collaboration with the European Association for the Study of Diabetes (EASD). Eur Heart J 2013; 34: 30353087. doi:10.1093/eurheartj/eht108

35. Czupryniak L, Barkai L, Bolgarska S, Bronisz A, Broz J, Cypryk K, et al.: Self-monitoring of blood glucose in diabetes: from evidence to clinical reality in Central and Eastern Europe - Recommendations from the International Central-Eastern European Expert Group. Diabetes Technol Ther 2014; 6: 460475. doi:10.1089/dia.2013.0302

36. Bailey TS, Grunberger G, Bode BW, Handelsman Y, Hirsch IB, Jovanovič L, et al.: American Association of Clinical Endocrinologists and American College of Endocrinology: 2016 Outpatient Glucose Monitoring Consensus Statement. Endocr Pract 2016; 22: 231-261. doi:10.4158/EP151124.CS

37. Lindström J, Tuomilehto J: The diabetes risk score. A practical tool to predict diabetes risk. Diabetes Care 2003; 26: 725-731. doi:10.2337/diacare.26.3.725

38. Jermendy Gy, Hidvégi T, Vándorfi Gy, Winkler G: A 2-es típusú diabetes és előállapotainak szűrése módszertani megfontolások, hazai lehetőségek. Orv Hetil 2010; 151: 689-695.
39. Li J, Bergmann A, Reimann M, Bornstein SR, Schwarz PEH: A more simplified Finnish diabetes risk score for opportunistic screening of undiagnosed Type 2 diabetes in a German population with a family history of the metabolic syndrome. Horm Metab Res 2009; 41: 98103. doi:10.1055/s-0028-1087191

40. International Expert Committee: International Expert Committee report on the role of the A1C assay in the diagnosis of diabetes. Diabetes Care 2009; 32: 1327-1334. doi:10.2337/dc09-9033

41. Report of a World Health Organization Consultation. Use of glycated haemoglobin $\left(\mathrm{HbA}_{1 \mathrm{c}}\right)$ in the diagnosis of diabetes mellitus. Diabetes Res Clin Pract 2011; 93: 299-309. doi:10.1016/j.diabres.2011.03.012

42. Sherwani SI, Khan HA, Ekhzaimy A, Masood A, Sakharkar MK: Significance of $\mathrm{HbA}_{1 \mathrm{c}}$ test in diagnosis and prognosis of diabetic patients. Biomark Insight 2016; 11: 95-104. doi:10.4137/BMI.S38440

43. Vásárhelyi B: Hemoglobin-A1c-szint-mérés: analitikai vonatkozások és ezek jelentősége a klinikai döntéshozatalban. Orv Hetil 2016; 157: 753-757. doi:10.1556/650.2016.30442

44. Nathan DM, Davidson MB, DeFronzo RA, Heine RJ, Henry RR, Pratley R, et al.: American Diabetes Association: Impaired fasting glucose and impaired glucose tolerance: implications for care. Diabetes Care 2007; 30: 753-759. doi:10.2337/dc07-9920

45. Jermendy Gy: A praediabetes klinikai jelentősége. Magyar Belorv Arch 2009; 62: 435-444.

46. Tabák AG, Herder C, Rathmann W, Brunner EJ, Kivimäki M: Prediabetes: a high-risk state for diabetes development. Lancet 2012; 379: 2279-2290. doi:10.1016/S0140-6736\%2812\%2960283-9

47. Reaven GM: Banting lecture 1988. Role of insulin resistance in human disease. Diabetes 1988; 37: 15951607. doi:10.2337/diab.37.12.1595

48. Després JP, Lemieux I: Abdominal obesity and metabolic syndrome. Nature 2006; 444: 881-887. doi:10.1038/nature05488

49. Halmos T, Kautzky L, Suba I: Mítosz vagy valóság? A metabolikus szindróma legújabb szemlélete. Tudomány Kiadó, Budapest, 2011.

50. Reaven GM: The metabolic syndrome: is this diagnosis necessary? Am J Clin Nutr 2006; 83: 1237-1247.

51. Grundy MS: Does the metabolic syndrome exist? Diabetes Care 2006; 29: 1689-1692. doi:10.2337/dc05-2307 
52. Kahn R, Buse J, Ferrannini E, Stern M: The metabolic syndrome: time for a critical appraisal. Joint statement from the American Diabetes Association and the European Association for the Study of Diabetes. Diabetologia 2005; 48: 1684-1699. doi:10.1007/s00125-005-1876-2

53. Simmons RK, Alberti KG, Gale EA, Colagiuri S, Tuomilehto J, Qiao Q, et al.: The metabolic syndrome: useful concept or clinical tool? Report of a WHO Expert Consultation. Diabetologia 2010; 53: 600-605. doi:10.1007/s00125-009-1620-4

54. Borch-Johnsen K, Wareham N: The rise and fall of the metabolic syndrome. Diabetologia 2010; 53: 597-599. doi:10.1007/s00125-010-1659-2

55. A metabolikus szindróma klinikai jelentősége 2011ben. A Magyar Diabetes Társaság Metabolikus Munkacsoportjának állásfoglalása (szerk: Jermendy Gy, írta: Barkai L, Halmos T, Hidvégi T, Jermendy Gy, Korányi L, Madácsy L, Pados Gy, Winkler G). Diabetologia Hungarica 2011; 19: 161-172.

56. American Diabetes Association (ADA): Diagnosis and classification of diabetes mellitus. Diabetes Care 2011; 34: S62-69. doi:10.2337/dc11-S062

57. Rubio-Cabezas O, Hattersley AT, Njølstad PR, Mlynarski W, White N, et al.; International Society for Pediatric and Adolescent Diabetes: The diagnosis and management of monogenic diabetes in children and adolescents. Pediatric Diabetes 2014; 15(Suppl 20): 47 64. doi:10.1111/pedi.12192

58. Hattersley A, Bruining J, Shields J, Njolstad P, Donaghue KC: The diagnosis and management of monogenic diabetes in children and adolascents. Pediatr Diabetes 2009; 10(Suppl 12): 33-42. doi:10.1111/j.1399-5448.2009.00571.x

59. Pánczél P, Hosszúfalusi N, Vatay Á, Horváth L, Karczagi V, Horváth R, et al.: Mitochondrialis génmutációhoz társuló diabetes mellitus: az első magyarországi család leírása. Diabetologia Hungarica 2004; 12: 199-206.

60. Pearson ER, Flechtner I, Njølstad PR, Malecki MT, Flanagan SE, Larkin B, et al.; Neonatal Diabetes International Collaborative Group: Switching from insulin to oral sulfonylureas in patients with diabetes due to Kir6.2 mutations. N Engl J Med 2006; 355: 467 477. doi:10.1056/NEJMoa061759

61. Gaál Z, Bakó B, Gárdus D, Gaál B, Spisák N, Balogh I: Neonatalis diabetes hátterének felnőttkori identifikálása. Diabetologia Hungarica 2013; 21: 7-14.
62. Gaal Z, Klupa T, Kantor I, Mlynarsky W, Albert L, Tolloczko J, et al.: Sulfonylurea use during entire pregnancy in diabetes because KCNJ11 mutation: A report of two cases. Diabetes Care 2012; 35: e1. doi:10.2337/dc12-0163

63. Iván G, Balogh I, Gaal Z, Mosonyi J, Szajbert T: Három évtizedes inzulinkezelés után diagnosztizált HNF1A-MODY (MODY3) esete - hogyan tovább? Diabetologia Hungarica 2016; 24: 48-52.

64. Jermendy G, Balogh I, Gaál Z: HNF-4- $\alpha$-mutáció okozta monogénes diabetes mellitus (MODY1) első hazai esete. Orv Hetil 2016; 157: 469-473. doi:10.1556/650.2016.30399

65. Shields BM, McDonald TJ, Ellard S, Campbell MJ, Hyde C, Hattersley AT: The development and validation of a clinical prediction model to determine the probability of MODY in patients with youngonset diabetes. Diabetologia 2012; 55: 1265-1272. doi:10.1007/s00125-011-2418-8

66. American Diabetes Association: Foundations of care and comprehensive medical evaluation. Diabetes Care 2016; 39(Suppl 1): S23-S35. doi:10.2337/dc16-S006

67. Evert AB, Boucher JL, Cypress M, Dunbar SA, Franz MJ, Mayer-Davis EJ, et al.: Nutrition therapy recommendations for the management of adults with diabetes. Diabetes Care 2013; 36: 3821-3842. doi:10.2337/dc13-2042

68. American Diabetes Association: Obesity management for the treatment of type 2 diabetes. Diabetes Care 2016; 39(Suppl. 1): S47-S51. doi:10.2337/dc16-S009

69. Kelly T, Dyson P (eds): Evidence-based nutrition guidelines for the prevention and management of diabetes. Diabetes UK 2011 May

70. https://www.diabetes.org.uk/Documents/Reports/ nutritional-guidelines-2013-amendment-0413.pdf

71. Manjunath CN, Rawal JR, Irani PM, Madhu K: Atherogenic dyslipidemia. Ind $\mathrm{J}$ Endocrinol Metab 2013; 17: 969-976. doi:10.4103\%2F2230-8210.122600

72. American Diabetes Association: Nutrition recommendations and interventions for diabetes. A position statement of the American Diabetes Association 2008; 31(Suppl. 1): S61-S78. doi:10.2337/dc08-S061

73. Gerő L, Hidvégi T, Winkler G: Édesítőszerek a cukorbetegek diétájában - mit és mennyit fogyaszthat a beteg? Diabetologia Hungarica 2016; 24: 7-14.

74. Horváth M: Fizikai aktivitás (in: Winkler G, Baranyi É /szerk./: Gyakorlati diabetológia 2010., Melánia Kiadó, Budapest, 2010.) pp. 73-85. 
75. Reiner M, Niermann C, Jekauc D, Will A: Long-term health benefits of physical activity - a systematic review of longitudinal studies. BMC Public Health. 2013 Sep 8; 13: 813. doi:10.1186/1471-2458-13-813

76. The Diabetes Control and Complications Trial Research Group: The effect of intensive treatment of diabetes on the development and progression of long-term complications in insulin-dependent diabetes mellitus. N Engl J Med 1993; 329: 977-986. doi:10.1056/NEJM199309303291401

77. Nathan DM, Cleary PA, Backlund JY, Genuth SM, Lachin JM, Orchard TJ, et al.; Diabetes Control and Complications Trial/Epidemiology of Diabetes Interventions and Complications (DCCT/EDIC) Research Group: Intensive treatment and cardiovascular disease in patients with type 1 diabetes. N Engl J Med 2005; 353: 2643-2653. doi:10.1056/NEJMoa052187

78. Diabetes Control and Complications Trial (DCCT)/ Epidemiology of Diabetes Interventions and Complications (EDIC) Study Research Group. Intensive Diabetes Treatment and Cardiovascular Outcomes in Type 1 Diabetes: The DCCT/EDIC Study 30-Year Follow-up. Diabetes Care 2016; 39: 686-693. doi:10.2337/dc15-1990

79. Ihnat MA, Thorpe JE, Ceriello A: Hypothesis: the "metabolic memory", the new challenge of diabetes. Diabet Med 2007; 24: 582-586. doi:10.1111/j.1464-5491.2007.02138.x

80. Jermendy Gy: Metabolikus memória diabetes mellitusban. Magyar Belorv Arch 2008; 61: 361-367.

81. Nádas J, Putz Zs, Fövényi J, Gaál Zs, Gyimesi A, Hidvégi T, et al.: Cardiovascular risk factors characteristic for the metabolic syndrome in adult patients with type 1 diabetes. Exp Clin Endocrinol Diabetes 2009; 117: 107112. doi:10.1055/s-0028-1082068

82. Rabasa-Lhoret Y, Burelle F, Ducros J, Bourque C, Lavoie D, Massicotte F, et al.: Use of an $\alpha$-glucosidase inhibitor to maintain glucose homeostasis during postprandial exercise in intensively treated type 1 diabetic subjects. Diabetic Medicine 2001; 18: 739-744. doi:10.1046/j.0742-3071.2001.00563.x

83. Pfustner A, Kustner E, Forst T, Schulze-Schleppinghoff B, Trautmann ME, Haslbeck M, et al, on the behalf of the German Insulin Lispro/IDDM study group: Intensive insulin therapy with insulin lispro in patients with type 1 diabetes reduces the frequency of hypoglycemic episodes. Exp Clin Endocrinol Diabetes 1996; 104: 23-30.
84. Ratner RR, Hirsch IB, Neifing J, Garg S, Mecca T, Wilson CA, for the U.S. Study Group of insulin glargine in type 1 diabetes: Less hypoglycemia with insulin glargine in intensive insulin therapy for type 1 diabetes. Diabetes Care 2000; 23: 639-643. doi:10.2337/diacare.23.5.639

85. Vague P, Selam J-L, Skeie S, De Leeuw I, Elte JW, Haahr $\mathrm{H}$, al: Insulin detemir is associated with more predictable glycemic control and reduced risk of hypoglycemia than NPH insulin in patients with type 1 diabetes on a basal-bolus regimen with premeal aspart. Diabetes Care 2003; 26: 590-596. doi:10.2337/diacare.26.3.590

86. Hermansen K, Fontaine P, Kukolja KK, Peterkova V, Leth G, Gall MA: Insulin analogues (insulin detemir and insulin aspart) vs. traditional human insulins (NPH insulin and regular human insulin) in basal-bolus therapy for patients with type 1 diabetes. Diabetologia 2004; 47: 622-629. doi:10.1007/s00125-004-1365-z

87. Home P, Bartley P, Russell-Jones D, Hanaire-Broutin H, Heeg JE, Abrams P, et al.; Study to Evaluate the Administration of Detemir Insulin Efficacy, Safety and Suitability (STEADINESS) Study Group: Insulin detemir offers improved glycemic control compared with NPH insulin in people with type 1 diabetes: a randomized clinical trial. Diabetes Care 2004; 27: 10811087. doi:10.2337/diacare.27.5.1081

88. Rosenstock J, Dailey G, Massi-Benedetti M, Fritsche A, Lin Z, Salzman A: Reduced hypoglycemia risk with insulin glargine: a meta-analysis comparing insulin glargine with human NPH insulin in type 2 diabetes. Diabetes Care 2005; 28: 950-955. doi:10.2337/diacare.28.4.950

89. Bartley PC, Bogoev M, Larsen J, Philotheou A: Longterm efficacy and safety of insulin detemir compared to neutral protamine Hagedorn insulin in patients with type 1 diabetes using a treat-to-target basalbolus regimen with insulin aspart at meals: a 2-year, randomized, controlled trial. Diabet Med 2008; 25: 442-449. doi:10.1111/j.1464-5491.2007.02407.x

90. Vora J, Christensen T, Rana A, Bain SC: Insulin degludec vs. insulin glargine in type 1 and type 2 diabetes mellitus: a meta-analysis of endpoints in phase 3a trials. Diabetes Ther 2014; 5: 435-446. doi:10.1007/s13300-014-0076-9

91. Heise T, Hermanski L, Nosek L, Feldman A, Rasmussen S, Haahr H: Insulin degludec: four times lower pharmacodynamic variability than insulin glargine under steady-state conditions in type 1 diabetes. Diabetes Obes Metab 2012; 14: 859-864. doi:10.1111/j.1463-1326.2012.01627.x 
92. Riddle MC, Bolli GB, Home PD, Bergenstal RM, Ziemen M, Muehlen-Bartmer I, et al.: Efficacy and safety of flexible vs. fixed dosing intervals of insulin glargine $300 \mathrm{U} / \mathrm{mL}$ in people with type 2 diabetes. Diabetes Technol Ther 2016; 18: 252-257. doi:10.1089/dia.2015.0290

93. Home PD, Bergenstal RM, Bolli GB, Ziemen M, Rojeski M, Espinasse M, et al.: New insulin glargine 300 units/mL vs. glargine 100 units/mL in people with type 1 diabetes: a randomized, phase $3 \mathrm{a}$, open-label clinical trial (EDITION 4). Diabetes Care 2015; 38: 2217-2225. doi:10.2337/dc15-0249

94. Jinnouchi H, Koyama M, Amano A, Takahashi Y, Yoshida A, Hieshima K, et al.: Continuous glucose monitoring during basal-bolus therapy using insulin glargine $300 \mathrm{U} \mathrm{mL}(-1)$ and glargine $100 \mathrm{U} \mathrm{mL}(-1)$ in Japanese people with type 1 diabetes mellitus: a crossover pilot study. Diabetes Ther 2015; 6: 143-152. doi:10.1007\%2Fs13300-015-0115-1

95. Hadjiyianni I, Dahl D, Lacaya LB, Pollom RK, Chang CL, Ilag LL: Efficacy and safety of LY2963016 insulin glargine in patients with type 1 and type 2 diabetes previously treated with insulin glargine. Diabetes Obes Metab 2016; 18: 425-429. doi:10.1111/dom.12628

96. Blevins TC, Dahl D, Rosenstock J, Ilag LL, Huster WJ, Zielonka JS, et al.: Efficacy and safety of LY2963016 insulin glargine compared with insulin glargine (Lantus) in patients with type 1 diabetes in a randomized controlled trial: the ELEMENT 1 study. Diabetes Obes Metab 2015; 17: 726-733. doi:10.1111/dom.12496

97. Raslova K: An update on the treatment of type 1 and type 2 diabetes mellitus: focus on insulin detemir, a long-acting human insulin analog. Vascular Health and Risk Management 2010; 6: 399-410. doi:10.2147/VHRM.S10397

98. Gyimesi A: A konzervatív inzulinkezelés. Diabetologia Hungarica 2004; 12(Suppl 2): 28-32.

99. Kautzky L: Inzulinpumpa (CSII) a diabetes kezelésének „gold standrad-ja. Diabetologia Hungarica 2004; 12(Suppl 2): 42-48.

100. Van Bon AC, Bode BW, Sert-Langeron C, DeVries $\mathrm{JH}$, Charpentier G: Insulin glulisine compared to insulin aspart and to insulin lispro administered by continuous subcutaneous insulin infusion in patients with type 1 diabetes: a randomized controlled trial. Diabetes Technol Ther 2011; 13: 607-614. doi:10.1089/dia.2010.0224
101. Tamborlane WV, Renard E, Wadwa RP, Blevins T, Jacober SJ, Liu R, et al.: Glycemic control after 6 days of insulin pump reservoir use in type 1 diabetes: results of double-blind and open-label cross-over trials of insulin lispro and insulin aspart. J Diabetes 2015; 7 : 270-278. doi:10.1111/1753-0407.12162

102. Ewald N, Hardt PD: Diagnosis and treatment of diabetes mellitus in chronic pancreatitis. World J Gastroenterol 2013; 19: 7276-7281. doi:10.3748/wjg.v19.i42.7276

103. Prospective Diabetes Study Group (UKPDS 33). Intensive blood glucose control with sulfonylureas or insulin compared with conventional treatment and risk of complication in patients with type 2 diabetes (UKPDS 33). Lancet 1998; 352: 837-853. doi:10.1016/S0140-6736\%2898\%2907019-6

104. Holman RR, Paul SK, Bethel MA, Matthews DR, Neil HA: 10-year follow-up of intensive glucose control in type 2 diabetes. N Engl J Med 2008; 359: 1577-1589. doi:10.1056/NEJMoa0806470

105. LeRoith D, Fonseca V, Vinik A: Metabolic memory in diabetes - focus on insulin. Diab Metab Res Rew 2005; 21: 85-90. doi:10.1002/dmrr.530

106. Jermendy G: Vascular memory - can we broaden the concept of the metabolic memory? Cardiovasc Diabetol 2012; 11: 44. doi:10.1186/1475-2840-11-44

107. ADVANCE Collaborative Group: Intensive blood glucose control and vascular outcomes in patients with type 2 diabetes. N Engl J Med 2008; 358: 2560-2572. doi:10.1056/NEJMoa0802987

108. Zoungas S, Chalmers J, Neal B, Billot L, Li Q, Hirakawa Y, et al.; ADVANCE-ON Collaborative Group: Follow-up of blood-pressure lowering and glucose control in type 2 diabetes. N Engl J Med 2014; 371: 1392-406. doi:10.1056/NEJMoa1407963

109. The Action to Control Cardiovascular Risk in Diabetes Study Group: Effects of intensive glucose lowering in type 2 diabetes. N Engl J Med 2008; 358: 2545-2559. doi:10.1056/NEJMoa0802743

110. Action to Control Cardiovascular Risk in Diabetes Follow-On (ACCORDION**) Eye Study Group and the Action to Control Cardiovascular Risk in Diabetes Follow-On (ACCORDION**) Study Group: Persistent effects of intensive glycemic control on retinopathy in type 2 diabetes in the action to control cardiovascular risk in diabetes (ACCORD*) follow-on study. Diabetes Care 2016; 39: 1089-1100. doi:10.2337/dc16-0024

111. Aguayo Rojas LB, Gomes MB: Metformin - an old but still the best treatment for type 2 diabetes. Diabetol Metab Syndr 2013; 5: 6. doi:10.1186/1758-5996-5-6 
112. Winkler G: Metformin - újabb adatok egy megbízható és hatékony „régi” vércukor-csökkentő készítményről. Orv Hetil 2016; 157: 883-892. doi:10.1556/650.2016.30485

113. Winkler G: DPP-4-gátlók: azonosságok és különbségek, a terápiaválasztás lehetséges szempontjai. Metabolizmus 2016; 14: 128-135.

114. Jermendy Gy, Winkler G: Inkretintengelyen ható terápia a diabetológiai gyakorlatban. Medicina Könyvkiadó, Budapest, 2016, pp. 1-250.

115. Winkler G: A dapagliflozin potenciális helye a 2-es típusú diabetes vércukorcsökkentő kezelésében. Diabetologia Hungarica 2015; 23: 25-31.

116. Jermendy Gy: Az inkretintengelyen ható antidiabetikumokkal végzett kardiovaszkuláris biztonságossági tanulmányok eddigi tapasztalatai. Orv Hetil 2016; 157: 603-610. doi:10.1556/650.2016.30416

117. Zinman B, Wanner C, Lachin JM, Bluhmki E, Hantel S, Mattheus M, et al for the EMPA-REG OUTCOME investigators: Empagliflozin, cardiovascular outcomes and mortality in type 2 diabetes. N Engl J Med 2015; 373: 2117-2128. doi:10.1056/NEJMoa1504720

118. Marso SP, Daniels GH, Brown-Frandsen K, Kristensen P, Mann JF, Nauck MA, et al.; LEADER Steering Committee on behalf of the LEADER Trial Investigators: Liraglutide and cardiovascular outcomes in type 2 diabetes. $\mathrm{N}$ Engl J Med 2016; 375: 311-322. doi:10.1056/NEJMoa1603827

119. Winkler G: Szulfanilureák napjaink vércukorcsökkentő kezelésében. Újabb adatok egy régi gyógyszercsoport előnyeiről és korlátairól. Orv Hetil 2015; 156 (13): 511515. doi:10.1556/OH.2015.30114

120. Winkler G: A hosszú és rövid hatású GLP-1-receptoragonisták áttekintése. A heti egyszeri adagolású GLP1-receptor-agonista dulaglutid (TRULICITYÒ) helye a 2-es típusú diabetes kezelésében. Diabetologia Hungarica 2016; 24: 101-112.

121. Gupta V: Glucagon-like peptide-1 analogues: an overview. Indian J Endocrinol Metab 2015; 17 (3): 413 421. doi:10.4103/2230-8210.111625

122. Winkler G: Az első fix kombinációjú bázisinzulinanalóg - GLP-1-mimetikum készítmény, a XultophyÒ farmakokinetikája és farmakodinamikája. Diabetologia Hungarica 2016; 24(Suppl 2): 10-16.

123. Jermendy Gy: Degludek + liraglutid fix kombináció (XultophyÒ) - új lehetőség az orális antidiabetikus kezelés elégtelenségekor 2-es típusú diabetesben. Diabetologia Hungarica 2016; 24(Suppl 2): 17-23.
124. Ahrén B: Insulin plus incretin: a glucose-lowering strategy for type 2 diabetes. World J Diabetes 2014; 5: 40-51. doi:10.4239/wjd.v5.i1.40

125. Kernan WN, Viscoli CM, Furie KL, Young LH, Inzucchi SE, Gorman M, et al.: Pioglitazone after ischemic stroke or transient ischemic attack. N Engl J Med 2016; 374: 1321-1331. doi:10.1056/NEJMoa1506930

126. Schernthaner G, Grimaldi A, Di Mario U, Drzewoski J, Kempler P, Kvapil M, et al.: GUIDE study: double-blind comparison of once-daily gliclazide MR and glimepiride in type 2 diabetic patients. Eur J Clin Invest 2004; 34(8): 535-542. doi:10.1111/j.1365-2362.2004.01381.x

127. Kántor I, Gaál Zs: Inzulinnal kezelt gyermekek sikeres átállítása szulfanilureára. Az első sikeres hazai terápiaváltások neonatalis diabetesben. In (in: Winkler G /szerk./: Orvosi esettanulmányok. Diabetológia. SpringMed Kiadó, Budapest, 2016.) pp. 36-47.

128. Iván G, Balogh I, Gaál Zs, Mosonyi J, Szajbert T: Három évtizedes inzulinkezelés után diagnosztizált HNF1A-MODY (MODY3) esete. Diabetologia Hungarica 2016; 24 (1): 48-52.

129. Baranyi É, Winkler G: Inzulinkezelés 2-es típusú diabetesben (in: Winkler G, Baranyi É /szerk./: Gyakorlati diabetológia 2010. Melania Könyvkiadó, Budapest, 2010.) pp. 131-138.

130. Hosszúfalusi N: Inzulinkezelés 2-es típusú diabetes mellitusban. Háziorvos Továbbképző Szemle 2012; 17: 11-15.

131. Holman RR, Thorne KI, Farmer AJ, Davies MJ, Keenan JF, Paul S, et al.: Addition of biphasic, prandial, or basal insulin to oral therapy in type 2 diabetes. N Engl J Med 2007; 357: 1716-1730. doi:10.1056/NEJMoa075392

132. Meneghini L, Kesavadev J, Demissie M, Nazeri A, Hollander P: Once-daily initiation of basal insulin as add-on to metformin: a 26-week, randomized, treatto-target trial comparing insulin detemir with insulin glargine in patients with type 2 diabetes. Diabetes Obes Metab 2013; 15: 729-736. doi:10.1111/dom.12083

133. Meneghini LF: Intensifying insulin therapy: what options are available to patients with type 2 diabetes? Am J Med 2013; 126: S28-37. doi:10.1016/j.amjmed.2013.06.011

134. Farcasiu E, Iványi T, Mozejko-Pastewska B, Birkus Z, Csoq J, Kowalska I, et al.: Efficacy and safety of prandial premixed therapy using insulin lispro mix 50/50 3 times daily compared with progressive titration of insulin lispro mix $75 / 25$ or biphasic insulin aspart 70/30 twice daily in patients with type 2 diabetes mellitus: a randomized, 16-week, open-label study. Clin Ther 2011; 33: 1682-1693. doi:10.1016/j.clinthera.2011.10.001 
135. Eng C, Kramer CK, Zinman B, Retnakaran R: Glucagon-like peptide-1 receptor agonist and basal insulin combination treatment for the management of type 2 diabetes: a systematic review and meta-analysis. Lancet 2014; 384: 2228-2234. doi:10.1016/S0140-6736\%2814\%2961335-0

136. Pozzilli $\mathrm{P}$, Norwood $\mathrm{P}$, Jodar E, Ivanyi T, Jiang H, Woodward B, et al.: Improved glycemic control and weight loss with once-weekly dulaglutide vs. placebo, both added to titrated daily insulin glargine, in type 2 diabetes patients (AWARD-9). Diabetes 2016; 65(Suppl 1): A62.

137. Lingvay I, Manghi FP, García-Hernández P, Norwood P, Lehmann L, Tarp-Johansen MJ, et al.; DUAL V Investigators. Effect of insulin glargine up-titration vs. insulin degludec/liraglutide on glycated hemoglobin levels in patients with uncontrolled type 2 diabetes: The DUAL V randomized clinical trial. JAMA 2016; 315: 898-907. doi:10.1001/jama.2016.1252

138. Blonde L, Jendle J, Gross J, Woo V, Jiang H, Fahrbach JL, et al.: Once-weekly dulaglutide vs. bedtime insulin glargine, both in combination with prandial insulin lispro, in patients with type 2 diabetes (AWARD-4): a randomised, open-label, phase 3, non-inferiority study. Lancet 2015; 385: 2057-2066. doi:10.1016/S0140-6736\%2815\%2960936-9

139. Rosenstock J, Jelaska A, Zeller C, Kim G, Broedl UC, Woerle HJ, et al.: Impact of empagliflozin added on to basal insulin in type 2 diabetes inadequately controlled on basal insulin: a 78-week randomized, double-blind, placebo-controlled trial. Diabetes Obes Metab 2015; 17: 936-948. doi:10.1111/dom.12503

140. Rosenstock J, Jelaska A, Frappin G, Salsali A, Kim G, Woerle HJ, et al.: Improved glucose control with weight loss, lower insulin doses, and no increased hypoglycemia with empagliflozin added to titrated multiple daily injections of insulin in obese inadequately controlled type 2 diabetes. Diabetes Care 2014; 37: 1815-1823. doi:10.2337/dc13-3055

141. Araki E, Onishi Y, Asano M, Kim H, Ekholm E, Johnsson E, et al.: Efficacy and safety of dapagliflozin in addition to insulin therapy in Japanese patients with type 2 diabetes: Results of the interim analysis of 16-week double-blind treatment period. J Diabetes Investig 2016; 7: 555-564. doi:10.1111/jdi.12453
142. Weng J, Li Y, Xu W, Shi L, Zhang Q, Zhu D, et al.: Effect of intensive insulin therapy on $\beta$-cell function and glycaemic control in patients with newly diagnosed type 2 diabetes: a multicentre randomised parallel-group trial. Lancet 2008; 371: 1753-1760. doi:10.1016/S0140-6736\%2808\%2960762-X

143. Retnakaran R, Drucker DJ: Intensive insulin therapy in newly diagnosed type 2 diabetes. Lancet 2008; 371: 1725-1726. doi:10.1016/S0140-6736\%2808\%2960736-9

144. Mannucci E, Monami M, Marchionni N: Short-acting insulin analogues vs. regular human insulin in type 2 diabetes: a meta-analysis. Diabetes Obes Metab 2009; 11: 53-59. doi:10.1111/j.1463-1326.2008.00934.x

145. Donner T, Munoz M: Update on insulin therapy for type 2 diabetes. J Clin Endocrinol Metab 2012; 97: 1405-1413. doi:10.1210/jc.2011-2202

146. Monami M, Marchionni N, Mannucci E: Long-acting insulin analogues vs. NPH human insulin in type 2 diabetes: a meta-analysis. Diabetes Res Clin Pract 2008; 81: 184-189. doi:10.1016/j.diabres.2008.04.007

147. Garber AJ, King AB, Del Prato S, Sreenan S, Balci MK, Muñoz-Torres M, et al.: Insulin degludec, an ultra-long acting basal insulin, vs. insulin glargine in basal-bolus treatment with mealtime insulin aspart in type 2 diabetes (BEGIN Basal-Bolus Type 2): a phase 3, randomised, openlabel, treat-to-target non-inferiority trial. Lancet 2012; 379: 1498-1507. doi:10.1016/S0140-6736\%2812\%2960205-0

148. Zinman B, Philis-Tsimikas A, Cariou B, Handelsman Y, Rodbard HW, Johansen T, et al.: Insulin degludec vs. insulin glargine in insulin-naive patients with type 2 diabetes: a 1-year, randomized, treat-to-target trial (BEGIN Once Long). Diabetes Care 2012; 35: 24642471. doi:10.2337/dc12-1205

149. Riddle MC, Bolli GB, Ziemen M, Muehlen-Bartmer I, Bizet F, Home PD, et al.: New insulin glargine 300 units/mL vs. glargine 100 units $/ \mathrm{mL}$ in people with type 2 diabetes using basal and mealtime insulin: glucose control and hypoglycemia in a 6-month randomized controlled trial (EDITION 1). Diabetes Care 2014; 37 : 2755-2562. doi:10.2337/dc14-0991

150. Yki-Järvinen $\mathrm{H}$, Bergenstal R, Ziemen M, Wardecki M, Muehlen-Bartmer I, Boelle E, et al.: New insulin glargine 300 units $/ \mathrm{mL}$ vs. glargine 100 units $/ \mathrm{mL}$ in people with type 2 diabetes using oral agents and basal insulin: glucose control and hypoglycemia in a 6-month randomized controlled trial (EDITION 2). Diabetes Care 2014; 37: 3235-3243. doi:10.2337/dc14-0990 
151. Bolli GB, Riddle MC, Bergenstal RM, Ziemen M, Sestakauskas K, Goyeau H, et al.: New insulin glargine $300 \mathrm{U} / \mathrm{ml}$ compared with glargine $100 \mathrm{U} / \mathrm{ml}$ in insulin-naïve people with type 2 diabetes on oral glucose-lowering drugs: a randomized controlled trial (EDITION 3). Diabetes Obes Metab 2015; 17: 386394. doi:10.1111/dom.12438

152. Ritzel R, Roussel R, Bolli GB, Vinet L, BrulleWohlhueter C, Glezer S, et al.: Patient-level metaanalysis of the EDITION 1, 2 and 3 studies: glycaemic control and hypoglycaemia with new insulin glargine $300 \mathrm{U} / \mathrm{ml}$ vs. glargine $100 \mathrm{U} / \mathrm{ml}$ in people with type 2 diabetes. Diabetes Obes Metab 2015; 17: 859-867. doi:10.1111/dom.12485

153. Hadjiyianni I, Dahl D, Lacaya LB, Pollom RK, Chang CL, Ilag LL: Efficacy and safety of LY2963016 insulin glargine in patients with type 1 and type 2 diabetes previously treated with insulin glargine. Diabetes Obes Metab 2016; 18: 425-429. doi:10.1111/dom.12628

154. Rosenstock J, Hollander P, Bhargava A, Ilaq LL, Pollom RK, Zielonka JS, et al.: Similar efficacy and safety of LY2963016 insulin glargine and insulin glargine (Lantus ${ }^{\circledR}$ ) in patients with type 2 diabetes who were insulin-naïve or previously treated with insulin glargine: a randomized, double-blind controlled trial (the ELEMENT 2 study). Diabetes Obes Metab 2015; 17: 734-741. doi:10.1111/dom.12482

155. Gerstein HC, Bosch J, Dagenais GR, Díaz R, Jung $\mathrm{H}$, Maggioni AP, et al.; ORIGIN Trial Investigators: Basal insulin and cardiovascular and other outcomes in dysglycemia. N Engl J Med 2012; 367: 319-328. doi:10.1056/NEJMoa1203858

156. Rosenstock J, Davies M, Home PD, Larsen J, Koenen C, Schernthaner G: A randomised, 52week, treat-to-target trial comparing insulin detemir with insulin glargine when administered as add-on to glucose-lowering drugs in insulin-naive people with type 2 diabetes. Diabetologia 2008; 51: 408-416. doi:10.1007/s00125-007-0911-x

157. Gruessner AC, Gruessner RW: Long-term outcome after pancereas transplantation: a registry analysis. Curr Opin Organ Transplant 2016; 21: 377-385. doi:10.1097/MOT.0000000000000331

158. Redfield RR, Scalea JR, Odorica JS: Simultaneous pancreas and kidney transplantation: current trends and future directions. Curr Opin Organ Transplant 2015; 20: 94-102. doi:10.1097/MOT.0000000000000146
159. Li Z, Mei S, Xiang J, Zhou J, Zhang O, Yau S, et al.: Influence of donor-recipient sex mismatch on longterm survival of pancreatic grarfts. Sci Rep 2016 Jul 12; 6: 29298. doi:10.1038/srep29298

160. Hering BJ, Clarke WR, Bridges ND, Eggerman $\mathrm{TL}$, Alejandro R, Bellin MD, et al.; Clinical Islet Transplantation Consortium: Phase 3 trial of transplantation of human islets in type 1 diabetes complicated by severe hypoglycemia. Diabetes Care 2016; 39: 1230-1234. doi:10.2337/dc15-1988

161. Gerő L: Langerhans-sziget transzplantáció, mesterséges ß-sejt-transzplantáció 1-es típusú diabetesben. Magyar Tudomány 2015; 176: 864-875.

162. American Diabetes Association: Obesity management for the treatment of type 2 diabetes. Diabetes Care 2016; 39(Suppl 1): S47-S51. doi:10.2337/dc16-S009

163. Horton ES, Silberman C, Davis KL, Berria R: Weight loss, glycemic control, and changes in cardiovascular biomarkers in patients with type 2 diabetes recieving incretin therapies or insulin in a large cohort databasis. Diabetes Care 2010; 33: 1759-1765. doi:10.2337/dc09-2062

164. Carlsson LMS, Peltonen M, Ahlin S, Anveden A, Bouchard C, Carlsson B, et al.: Bariatric surgery and prevention of type 2 diabetes in Swedish Obese Subjects. N Engl J Med 2012; 367: 695-704. doi:10.1056/NEJMoa1112082

165. Winkler G: A súlyleadás sebészetének (bariátriai sebészet) anyagcsere vonatkozásai. Orv Hetil 2013; 154: 3-9. doi:10.1556/OH.2013.29517

166. Rothberg AE, McEwen LN, Kraftson AT, Fowler CE, Herman WH: Very-low-energy diet for type 2 diabetes: an underutilized therapy? J Diab Compl 2014; 28: 506510. doi:10.1016/j.jdiacomp.2014.03.014

167. Apovian CM, Aronne LJ, Bessesen DH, McDonnell ME, Murad MH, Pagotto U, et al.: Pharmacological management of obesity: an endocrine society clinical practical guide-line. J Clin Endocrinol Metab 2015; 100: 342-362. doi:10.1210/jc.2014-3415

168. Karpe F, Dickmann JR, Frayn KN: Fatty acids, obesity and insulin resistance: time for a reevaluation. Diabetes 2011; 60: 2441-2449. doi:10.2337/db11-0425

169. Rubino F, Nathan DM, Eckel RH, Schauer PR, Alberti KG, Zimmet PZ, et al.; Delegates of the 2nd Diabetes Surgery Summit: Metabolic surgery in the treatment algorithm for type 2 diabetes: A Joint Statement by International Diabetes Organizations. Diabetes Care 2016; 39: 861-877. doi:10.2337/dc16-0236 
170. Bradley D, Magkos F, Klein S: Effect of bariatric surgery on glucose homeostasis and type 2 diabetes. Gastroenterology 2012; 143: 897-912. doi:10.1053/j.gastro.2012.07.114

171. Coleman KJ, Haneuse S, Johnson E, Bogart A, Fisher $\mathrm{D}, \mathrm{O}$ 'Connor PJ, et al.: Long-term microvascular disease outcomes in patients with type 2 diabetes after bariatric surgery: evidence for the legacy effect of surgery. Diabetes Care 2016; 39:1400-1407. doi:10.2337/dc16-0194

172. Busetto L: Timing of bariatric surgery in people with obesity and diabetes. Ann Transl Med 2015; 3: 94. doi:10.3978\%2Fj.issn.2305-5839.2015.03.62

173. Mingrone G, Panunzi S, De Gaetano A, Guidone C, Iaconelli A, Leccesi L, et al.: Bariatric surgery vs. conventional medical therapy for type 2 diabetes. $\mathrm{N}$ Engl J Med 2012; 366: 1577-1585. doi:10.1056/NEJMoa1200111

174. Folli F, Pontiroli AE, Schwesinger WH: Metabolic aspects of bariatric surgery. Med Clin N Am 2007; 91: 393-414. doi:10.1016/j.mcna.2007.01.005

175. Schneider BE, Mun EC: Surgical management of morbid obesity. Diabetes Care 2005; 28: 475-480. doi:10.2337/diacare.28.2.475

176. American Diabetes Association: Management of diabetes in pregnancy. Diabetes Care 2016; 39(Suppl 1): S94-S98. doi:10.2337/dc16-S015

177. Baranyi É, Békefi D, Csákány MGy, Winkler G. (szerk.): Diabetes és terhesség. A Magyar Diabetes Társaság Terhesdiabetológiai munkacsoportjának útmutatója. Diabetologia Hungarica 2013; 21(Suppl 2): 5-64.

178. Baranyi É, Békefi D, Bitó T, Csákány MGy, Földesi I, Hajós P, et al.: (szerk.: Baranyi É, Winkler G): Javaslat a terhesség alatti glukózanyagcsere-zavarok felismerésére. A Magyar Diabetes Társaság (MDT) Diabétesszel Társuló Terhességgel Foglalkozó Munkacsoportja 2015. október 6-i kerekasztal-megbeszélésének ajánlásai. Diabetologia Hungarica 2016; 24: 85-88.

179. Dabelea D, Crume, T: Maternal environment and the transgenerational circle of obesity and diabetes. Diabetes 2011; 60: 1849-1855. doi:10.2337/db11-0400

180. The HAPO Study Cooperative Research Group: Hyperglycemia and adverse pregnancy outcomes. N Engl J Med 2008; 358: 1991-2002. doi:10.1056/NEJMoa0707943

181. International Association of Diabetes and Pregnancy Study Groups Consensus Panel (IADPSG): International Association of Diabetes and Pregnancy Study Groups recommendations on diagnosis and classification of hyperglycemia in pregnancy. Diabetes Care 2010; 33: 676-682. doi:10.2337/dc09-1848
182. WHO: Diagnostic criteria and classification of hyperglycemia first diagnosed in pregnancy. WHO, Geneva, 2013. http://www.who.int/iris/bitstream/10665/ 85975/WHO_NMH_MND_13.2

183. Benhalima KI, Mathieu C, Damm P, Van Assche A, Devlieger R, Desove G, et al.: A proposal for the use of uniformed diagnostic criteria for gesstational diabetes in Europe: an opinion paper by the European Board and College of Obstetrics and Gynecology (EBCOG). Diabetologia 2015; 58: 1422-1429. doi:10.1007/s00125-015-3615-7

184. American Diabetes Association: Standards of medical care in diabetes 2014. Diabetes Care 2014; 37(Suppl 1): S14-S80. doi:10.2337/dc14-S014

185. American College of Obstetricians and Gynecologists: Gestational diabetes mellitus. Practice Bulletin No 137. Obstet Gynecol 2013; 122: 4006-4016. doi:10.1097/01.AOG.0000433006.09219.f1

186. National Collaborating Center for Womens and Childrens Health: Diabetes in pregnancy: management of diabetes and its complications from preconception to the postnatal period. http://www.nice.org.uk/guidance/ ng3/resources/diabetes-in-pregnancy-management-ofdiabetes-and-its-complications-from-preconception-tothe-postnatal-period-51038446021

187. The International Federation of Gynecology and Obstetrics (FIGO): Initiative of gestational diabetes mellitus: a pragmatic guide for diagnosis, management and care. Intern J Gynecol Obstet 2015; 131(Suppl 3): S173-S211. doi:10.1016/S0020-7292\%2815\%2930033-3

188. Lambert K, Holt RIG: The use of insulin analogues in pregnancy. Diabetes Obes Metab 2013; 15: 888-900.

189. Baranyi É, Winkler G: Diabetes és terhesség. Orv Hetil 2011; 152: 1635-1640. doi:10.1556/OH.2011.29192

190. Maji D, Shaikh S, Solanki D, Gauray K: Safety of statins. Ind J Endocrinol Metab 2013; 17: 636-646. doi:10.4103/2230-8210.113754

191. Jermendy Gy, Nagy A, Tölgyesi R, Tamás Gy: Vércukor-önellenőrzés és telemedicina: a Dcont.hu adatbázis elemzésének első tapasztalatai. Diabetologia Hungarica 2011; 19: 298-304, 2011.

192. Jermendy Gy, Kecskés Á, Nagy A, Ági T, Bibok Gy: Internet-alapú támogatás vércukor-önellenőrzést végző cukorbetegek számára: a Dcont ${ }^{\circledR}$ eNAPLÓ 2010-2015 közötti adatainak elemzése. Diabetologia Hungarica 2016; 24 (1): 27-34.

193. Fövényi J: A vércukor-önellenőrzés története és hazai vonatkozásai. Diabetologia Hungarica 2005; 13: 273282. 
194. Polonsky WH, Fisher L, Schikman $\mathrm{CH}$, Hinnen DA, Parkin CG, Jelsovsky Z, et al.: Structured selfmonitoring of blood glucose significantly reduces A1C levels in poorly controlled, noninsulin-treated type 2 diabetes: results from the Structured Testing Program study. Diabetes Care 2011; 34: 262-267. doi:10.2337/dc10-1732

195. Winkler G, Barkai L, Jermendy Gy: A vércukorönellenőrzés gyakorlati szempontjai. A Magyar Diabetes Társaság konszenzus-értekezletének állásfoglalásai. Diabetologia Hungarica 2007; 15(Suppl 2): 40-43.

196. International Diabetes Federation: Self-monitoring of blood glucose in non-insulin-treated type 2 diabetes. Recommendations based on a workshop of the IDF Clinical Guidelines Taskforce in collaboration with the SMBG International Working Group. Brussels, 2009.

197. Klonoff DC, Blonde L, Cembrowski G, Chacra AR, Charpentier G, Colagiuri S, et al.; Coalition for Clinical Research-Self-Monitoring of Blood Glucose Scientific Board: Consensus report: the current role of self-monitoring of blood glucose in non-insulin-treated type 2 diabetes. J Diabetes Sci Technol 2011; 5: 1529 1548. doi:10.1177/193229681100500630

198. McIntosh B, Yu C, Lal A, Chelak K, Cameron C, Singh SR, et al.: Efficacy of self-monitoring of blood glucose in patients with type 2 diabetes mellitus managed without insulin: a systematic review and meta-analysis. Open Med 2010; 4: e102-e113.

199. Farmer AJ, Perera R, Ward A, Heneghan C, Oke J, Barnett $\mathrm{AH}$, et al.: Meta-analysis of individual patient data in randomised trials of self monitoring of blood glucose in people with non-insulin treated type 2 diabetes. BMJ 2012; 344: e486. doi:10.1136/bmj.e486

200. Malanda UL, Welschen LM, Riphagen II, Dekker JM, Nijpels G, Bot SD: Self-monitoring of blood glucose in patients with type 2 diabetes mellitus who are not using insulin. Cochrane Database Syst Rev 2012; 1: CD005060. doi:10.1002/14651858.CD005060.pub3

201. Ohkubo Y, Kishikawa H, Araki E, Miyata T, Isami $\mathrm{S}$, Motoyoshi $\mathrm{S}$, et al.: Intensive insulin therapy prevents the progression of diabetic microvascular complications in Japanese patients with non-insulindependent diabetes mellitus: a randomized prospective 6-year study. Diabetes Res Clin Pract 1995; 28: 103 117. doi:10.1016/0168-8227\%2895\%2901064-K
202. Murata GH, Shah JH, Hoffman RM, Wendel CS, Adam KD, Solvas PA, et al.; Diabetes Outcomes in Veterans Study (DOVES): Intensified blood glucose monitoring improves glycaemic control in stable, insulin-treated veterans with type 2 diabetes: the Diabetes Outcomes in Veterans Study (DOVES). Diabetes Care 2003; 26: 1759-1763. doi:10.2337/diacare.26.6.1759

203. Martin S, Schneider B, Heinemann L, Ludwig V, Kurth HJ, Kolb H, Scherbaum WA. for the ROSSO Study Group: Self-monitoring of blood glucose in type 2 diabetes and long-term outcome: an epidemiological cohort study. Diabetologia 2006; 49: 271-278. doi:10.1007/s00125-005-0083-5

204. Durán A, Martín P, Runkle I, Pérez N, Abad R, Fernández $\mathrm{M}$, et al.: Benefits of self-monitoring blood glucose in the management of new-onset type 2 diabetes mellitus: the St Carlos Study, a prospective randomized clinic-based interventional study with parallel groups. J Diabetes 2010; 2: 203-211. doi:10.1111/j.1753-0407.2010.00081.x

205. Polonsky WH, Fisher L, Schikman CH, Hinnen DA, Parkin CG, Jelsovsky Z, et al.: A structured selfmonitoring of blood glucose approach in type 2 diabetes encourages more frequent, intensive, and effective physician interventions: results from the STeP study. Diabetes Technol Ther 2011; 13: 797-802. doi:10.1089/dia.2011.0073

206. Scavini M, Bosi E, Ceriello A, Giorgino F, Porta M, Tiengo A, et al.: Prospective, randomized trial on intensive SMBG management added value in noninsulin-treated T2DM patients (PRISMA): a study to determine the effect of a structured SMBG intervention. Acta Diabetol 2013; 50: 663-672. doi:10.1007/s00592-011-0357-y

207. In vitro diagnostic test systems - requirements for blood-glucose monitoring systems for self-testing in managing diabetes mellitus. ISO 15197:2003.

208. In vitro diagnostic test systems - requirements for blood-glucose monitoring systems for self-testing in managing diabetes mellitus. ISO 15197:2013.

209. Jermendy Gy, Szabó A, Barkai L, Hidvégi T, Winkler G: A Dcont IDEÁL mérési pontossága laboratóriumi és klinikai körülmények között. Diabetologia Hungarica 2013; 21: 227-235.

210. American Diabetes Association. Standards of Medical Care in Diabetes - 2016. Diabetes Care 2016; 39(Suppl1): S39-S46. doi:10.2337/dc16-S008 
211. Juvenile Diabetes Research Fuundation Continuous Glucose Study Group Trial Tamborlain WW, Beck R, et al.: Continuous glucose monitoring and intensive treatment in type 1 diabetes. N Engl J Med 2008; 359: 1464-1476. doi:10.1056/NEJMoa0805017

212. Klonoff DC, Buckingham B, Christiansen JS, Montori VM, Tamborlane WV, Vigersky RA, et al.: Continuous Glucose Monitoring: an Endocrine Society Clinical Practice Guideline. J Clin Endocrinol Metab 2011; 96: 2968-2979. doi:10.1210/jc.2010-2756

213. Körner A, Gaál Z: Kommentár az AACE klinikai gyakorlati irányelvéhez. Diabetologia Hungarica 2012; 20: $37-40$.

214. General practice management of type 2 diabetes 2014-15. Melbourne: The Royal Australian College of General Practitioners and Diabetes Australia, 2014.

215. International Diabetes Federation 2012: Clinical Guidelines Task Force Global Guideline for Type 2 Diabetes, IDF, Brussels, Belgium.www.idf@idf.org

216. NICE: Guidance on the use of patient education models for diabetes. Technology appraisal 60. London.

217. Powers MA, Bardsley J, Cypress M, Duker P, Funnel MM, Hess Fischl A, et al.: Diabetes self-management education and support in type 2 diabetes: a joint position statement of the American Diabetes Association, the American Association of Diabetes Educators, and Academy of Nutrition and Dietetics. Diabetes Care 2015; 38: 1372-1382. doi:10.2337/dc15-0730

218. Hidvégi T: Páciensedukáció - a cukorbeteg-gondozás nélkülözhetetelen eleme. Orv Hetil 2011; 152: 19411948. doi:10.1556/OH.2011.29262

219. Vialettes B, Valero R, Mattei C, Nervi S: Prevention of type 1 diabetes: what have we achieved? What should we say and propose next to families? Diabetes Metab 2003; 29: 650-654. doi:10.1016/S1262-3636\%2807\%2970082-4

220. Skyler JS: Prevention of type 1 diabetes. In: The evidence base for diabetes care (Eds: Herman WH, Kinmoth AL, Wareham NJ, Williams R.) Wiley-Blackwell, 2010. pp. 31-48. doi:10.1002/9780470682807.ch4

221. Jermendy G: Can type 2 diabetes be considered preventable? Diab Res Clin Pract 2005; 68(Suppl 1): S73-S81. doi:10.1016/j.diabres.2005.03.010

222. Simmons RK, Unwin N, Griffin SJ: International Diabetes Federation: An update of the evidence concerning the prevention of type 2 diabetes. Diabetes Res Clin Pract 2010; 87: 143-149. doi:10.1016/j.diabres.2009.10.003
223. Yoon U, Kwok LL, Magkidis A: Efficacy of lifestyle interventions in reducing diabetes incidence in patients with impaired glucose tolerance: a systematic review of randomized controlled trials. Metabolism 2013; 62(2): 303-314. doi:10.1016/j.metabol.2012.07.009

224. Pan XR, Li GW, Hu YH, Wang JX, Yang WY, An $\mathrm{ZX}$, et al.: Effects of diet and exercise in preventing NIDDM in people with impaired glucose tolerance: the Da Qing IGT and Diabetes Study. Diabetes Care 1997; 20: 537-544. doi:10.2337/diacare.20.4.537

225. Tuomilehto J, Lindström J, Eriksson JG, Valle TT, Hamalainen H, Ilanne-Parikka P, et al.; Finnish Diabetes Prevention Study Group: Prevention of type 2 diabetes mellitus by changes in lifestyle among subjects with impaired glucose tolerance. N Engl J Med 2001; 344: 1343-1350. doi:10.1056/NEJM200105033441801

226. Diabetes Prevention Program Research Group: Reduction in the incidence of type 2 diabetes with lifestyle intervention or metformin. $\mathrm{N}$ Engl $\mathrm{J}$ Med 2002; 346: 393-403. doi:10.1056/NEJMoa012512

227. Gong Q, Gregg EW, Wang J, An Y, Zhang P, Yang W, et al.: Long-term effects of a randomised trial of a 6-year lifestyle intervention in impaired glucose tolerance on diabetes-related microvascular complications: the China Da Qing Diabetes Prevention Outcome Study. Diabetologia 2011; 54: 300-307. doi:10.1007/s00125-010-1948-9

228. Li G, Zhang P, Wang J, An Y, Gong Q, Gregg EW, et al:: Cardiovascular mortality, all-cause mortality, and diabetes incidence after lifestyle intervention for people with impaired glucose tolerance in the $\mathrm{Da}$ Qing Diabetes Prevention Study: a 23-year follow-up study. Lancet Diabetes Endocrinol 2014; 2: 474-480. doi:10.1016/S2213-8587\%2814\%2970057-9

229. Lindström J, Ilanne-Parikka P, Peltonen M, Aunola S, Eriksson JG, Hemiö K, et al.; Finnish Diabetes Prevention Study Group: Sustained reduction in the incidence of type 2 diabetes by lifestyleintervention: follow-up of the Finnish Diabetes Prevention Study. Lancet 2006; 368: 1673-1679. doi:10.1016/S0140-6736\%2806\%2969701-8

230. Chiasson JL, Josse RG, Gomis R, Hanefeld M, Karasik A, Laakso M. for the STOP-NIDDM Trial Research Group: Acarbose for prevention of type 2 diabetes mellitus: The STOP-NIDDM randomised trial. Lancet 2002; 359: 2072-2077. doi:10.1016/S0140-6736\%2802\%2908905-5 
231. NAVIGATOR Study Group: Effect of valsartan on the incidence of diabetes and cardiovascular events. $\mathrm{N}$ Engl J Med 2010; 362: 1477-1490. Erratum in: N Engl J Med 2010; 362: 1748. doi:10.1056/NEJMoa1001121

232. Torgerson JS, Hauptman J, Boldrin MN, Sjöström L: Xenical in the prevention of diabetes in obese subjects (XENDOS) study. A randomized study of orlistat as an adjunct to lifestyle changes for the prevention of type 2 diabetes in obese patients. Diabetes Care 2004; 27 : 155-161. doi:10.2337/diacare.27.1.155

\section{Fejlesztés módszere}

\section{Fejlesztőcsoport megalakulása, a fejlesztési folyamat és a feladatok dokumentálásának módja}

A szakmai irányelv fejlesztésében a Belgyógyászati, Endokrinológiai, Diabetes és Anyagcsere-betegségek Szakmai Kollégium tagjai, ill. az MDT vezetőségének kijelölt tagjai vettek részt.

A szakmai irányelv vázlatát, a fejlesztés módszerét, a kézirat elkészítésének módját az MDT vezetősége a 2016. szeptember 4-én tartott vezetőségi ülésen jóváhagyta. Az elkészült első változatot a vezetőség tagjai kézhez kapták és jóváhagyták.

A szakmai irányelv megírásában a szerzők az alábbiak szerint vettek részt:

Dr. Jermendy György: A kézirat szerkesztése, az első, majd a végleges változat összeállítása, az alábbi szakmai fejezetek írása: Meghatározások, Bevezetés, Diagnózis, Klasszifikáció, Az 1-es típusú diabetes antihyperglykaemiás kezelése, Vércukor-önellenőrzés, Megelőzés.

Dr. Gaál Zsolt: Az alábbi fejezetek írása: Monogénes diabetes, CGMS

Dr. Gerő László: Az alábbi fejezet írása: Pancreas- és Langerhans-sziget-transzplantáció

Dr. Hidvégi Tibor: Az alábbi fejezet írása: Gondozás, betegoktatás

Dr. Kempler Péter: Az alábbi fejezetek írása: Az 1-es típusú diabetes antihyperglykaemiás kezelése, Inzulinkezelés 2-es típusú diabetesben

Dr. Winkler Gábor: Az alábbi fejezetek írása: Orvosi táplálkozásterápia, Fizikai aktivitás, Nem-in-
233. Xiang AH, Peters RK, Kjos SL, Marroquin A, Goico J, Ochoa C, et al.: Effect of pioglitazone on pancreatic beta-cell function and diabetes risk in Hispanic women with prior gestational diabetes. Diabetes 2006; 55: $517-$ 522. doi:10.2337/diabetes.55.02.06.db05-1066

234. Barkai L, Blatniczky L, Halmos T-né, Hidvégi T, Jermendy Gy, Kaló Z, et al.: Nemzeti Diabetesprogram 2011 (szerk: Jermendy Gy). Diabetologia Hungarica 2011; 19(Suppl 3), 5-39.

zulintermészetű gyógyszerekkel történő kezelés 2-es típusú diabetesben, Diabetes és terhesség, Súlytöbblet/elhízás kezelése

Dr. Wittmann István: A kézirat első változatának lektorálása

A szakmai irányelv érvénybe lépése: a hivatalos megjelenést követő hónap első napja.

A szakmai irányelv szöveghủ változata a hivatalos megjelenéssel egy időben felkerül az MDT honlapjára és az megjelenik a Diabetologia Hungarica 2017. évi 1. számaként is.

\section{Irodalomkeresés, szelekció}

Az irodalomkutatás idejének lezárása: 2016. aug. 1.

A témakörben létezik folyamatosan frissített amerikai és európai szakmai irányelv. Emellett számos ország elkészítette saját, a fentieken alapuló nemzeti ajánlásait. A hazai szakmai irányelv értelemszerűen az ADA/EASD ajánlásain alapszik elsősorban. Irodalomkutatás történt a Web of Science, Medline és PubMed adatbázisok segítségével az alábbi kulcsszavak használatával: diabetes mellitus, type 1 diabetes, type 2 diabetes, antidiabetic treatment, oral antidiabetic drugs, glycaemic control, care of diabetes, prevention of diabetes, classification of diabetes, diagnosis of diabetes, self-monitoring of blood glucose, továbbá a kezelésben használatos valamennyi gyógyszer neve. 
3. Felhasznált bizonyítékok erősségének, hiányosságainak leírása (kritikus értékelés, „bizonyíték vagy ajánlás mátrix"), bizonyítékok szintjének meghatározási módja

A felhasznált bizonyítékokat a fejlesztő csoport kritikus szemmel értékelte, kitérve az adott vizsgálat módszertanára, elemszámára, jellegére, tartamára és klinikai relevanciájára. A besorolást (bizonyítékok szintje) ezek alapján konszenzussal állapítottuk meg.

\section{Melléklet}

\section{Alkalmazást segítő dokumentumok}

\subsection{Betegtájékoztató, oktatási anyagok}

Betegedukációnál hasznosítható honlapok:

- http://www.diabet.hu (Itt a páciens oldalon megtalálható a „Teljes élet cukorbetegen” kiadvány és több, fontos betegtájékoztató anyag)

- http://www.diabetes.hu

- http://diabforum.hu

- http://www.learningaboutdiabetes.org

- https://www.niddk.nih.gov/health-information/health-communicationprograms/ndepPages/index

- https://www.diabeteseducator.org/about-aade/media-center/press-releases/press-releases/2015/08/31/new-website-for-the-american-association-of-diabetes-educators-is-named-by-sitefinity-as-one-of-the-top-5-websites-of-the-quarter

- www.diabeteseducator.org.

- http://www.dce.org/public-resources/diabetes

\subsection{Tevékenységsorozat elvégzésekor használt ellenőrző kérdőívek, adatlapok}

- Jermendy Gy: Tényeken alapuló cukorbeteg-gondozás. Medicina Kiadó Zrt., Budapest, 2005.

\section{Ajánlások kialakításának módszere}

A végső döntés konszenzuson alapult.

\section{Véleményezés módszere}

Minden vélemény kialakítása konszenzuson alapult.

\section{Független szakértői véleményezés módszere}

Független szakértő nem működött közre.

- Fövényi J, Soltész Gy: Inzulinnal kezeltek kézikönyve. SpringMed Kiadó Kft., Budapest, 2009.

- Baranyi É, Winkler G: A nő és a cukorbetegség. SpringMed Kiadó Kft., Budapest, 2009.

- Somogyi A, Rosta K (szerk): Felnőttoktatás a cukorbetegségről. Medicina Kiadó Kft., Budapest, 2010.

- Halmos T, Kautzky L, Suba I: Mítosz vagy valóság? A metabolikus szindróma legújabb szemlélete. Tudomány Kiadó Kft., Budapest, 2011.

- Winkler G, Baranyi É (szerk): Gyakorlati diabetológia 2010., Melania Kiadó Kft., Budapest, 2010.

- Winkler G (szerk): Diabetológia a háziorvosi gyakorlatban. SpringMed Kiadó Kft., Budapest, 2012.

- Gerő L, Jermendy Gy: Inzulinanalógok a klinikai gyakorlatban. Medicina Könyvkiadó Zrt., Budapest, 2014.

- Winkler G, Jermendy Gy: Diabetes mellitus. Gyakori kérdések - gyakorlati válaszok. Tudomány Kiadó Kft, Budapest, 2015.

- Winkler G (szerk): Orvosi esettanulmányok diabetológia. SpringMed Kiadó Kft., Budapest, 2016.

- Jermendy Gy, Winkler G: Inkretintengelyen ható terápia a diabetológiai gyakorlatban. Medicina Könyvkiadó Zrt., Budapest, 2016. 


\subsection{Táblázatok}

1. táblázat. Az OGTT (orális glukóztolerancia-teszt) helyes kivitelezésének kritériumai

2. táblázat. A normális glukóztolerancia és a szénhidrátanyagcsere-zavarok diagnosztikai kritériumai (WHO, 2006) ${ }^{2}$

3. táblázat. A $\mathrm{HbA}_{1 \mathrm{c}}$-érték kategóriái az $\mathrm{ADA}$ ajánlása ${ }^{5}$ alapján

4. táblázat. A szénhidrátanyagcsere-zavarok etiológiai klasszifikációja (WHO, 2006) ${ }^{2}$

5. táblázat. A heveny anyagcsere-kisiklás formái 2-es típusú diabetesben

6. táblázat. A metformin rendelésének biztonsági előírásai

7. táblázat. A 2-es típusú diabetes vércukorcsökkentő kezelésének választásakor mérlegelendő körülmények

8. táblázat. Az antidiabetikumok hatástani felosztása

9. táblázat. A 2-es típusú diabetes kezelésében használatos antidiabetikumok adásakor mérlegelendő körülmények

10. táblázat. Preferálandó antidiabetikus terápia 2-es típusú diabetesben

11. táblázat. A két inkretinhatású gyógyszercsoport főbb, klinikai vonatkozású különbségei

12. táblázat. A rövid (prandialis) és hosszú hatású (nem-prandialis) GLP-1-receptoragonisták jellemzői

13. táblázat. Az elhízás konzervatív kezelése és a súlyleadást segítő mütétek kimeneti mutatói több vizsgálatt, ${ }^{4,14,15,16}$ adatai alapján

14. táblázat. Bariátriai műtétre való alkalmasság sebészi szempontjai ${ }^{164,174}$

15. táblázat. A prekoncepcionális gondozás feladatai az alapellátásban és az intenzív, interdiszciplináris szakellátásban

16. táblázat. Kezelési célértékek prekoncepcionális gondozás, illetve várandósság idején ${ }^{176}$

17. táblázat. A várandósság szakmai szempontok alapján nem tanácsolt cukorbetegségben

18. táblázat. Gesztációs diabetes mellitus (GDM) szűrése (az MDT Terhesdiabetológiai Munkacsoportja hatályos állásfoglalása ${ }^{177}$ )

19. táblázat. Gesztációs diabetes mellitus (GDM) szempontjából fokozott kockázatú egyének
20. táblázat. A vércukor-önellenőrzés céljai 1-es és 2-es típusú diabetesben ${ }^{35}$

21. táblázat. A diabetes/prediabetes vonatkozásában fokozott kockázatot jelentő állapotok

\subsection{Algoritmusok}

3. ábra. Szakmailag megalapozott terápiás lépések az újonnan felismert 2-es típusú diabetes mellitus kezelésekor

4. ábra. Szakmailag megalapozott terápiás lépések a 2-es típusú diabetes mellitus évekre elnyúló kórlefolyása során

6. ábra. Az inzulinterápia intenzifikálása 2-es típusú diabetesben (kiindulási helyzet: bázisinzulin-terápia)

\subsection{Egyéb dokumentumok}

1. ábra. A hyperglykaemia kezelési szigorúságának megítélését segítő döntéshozatali elemek ábrázolása (Forrás: Inzucchi et al.: Diabetes Care 2015; 38[1]: 140-149.)

2. ábra. A glukózanyagcsere rendellenességei: típusok és stádiumok (Forrás: Diabetes Care 2011; 34[Suppl.1])

5. ábra. Antidiabetikumok alkalmazási lehetősége idült vesebetegség, csökkent vesefunkció esetén (Forrás: Canadian Diabetes Association Clinical Practice Guidelines Expert Committee: Can J Diabetes 2015; 39: 250-252.) 